\title{
Designing Potassium Battery Salts through a Solvent-in-Anion Concept for Concentrated Electrolytes and Mimicking Solvation Structures
}

Luke A. Schkeryantzł, Jingfeng Zhengł, William D. McCulloch, Lei Qin, Songwei Zhang, Curtis E. Moore, Yiying Wu*

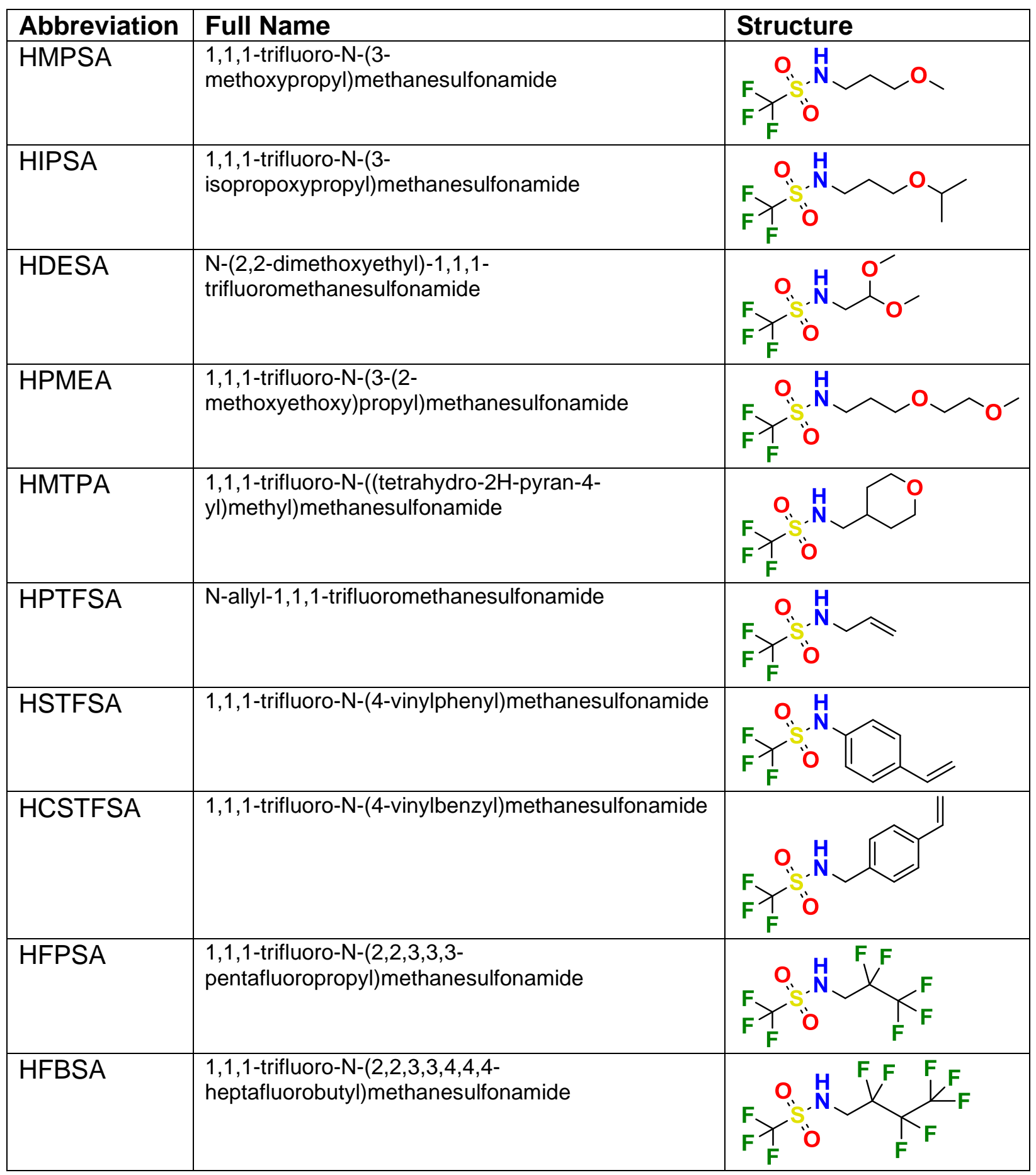




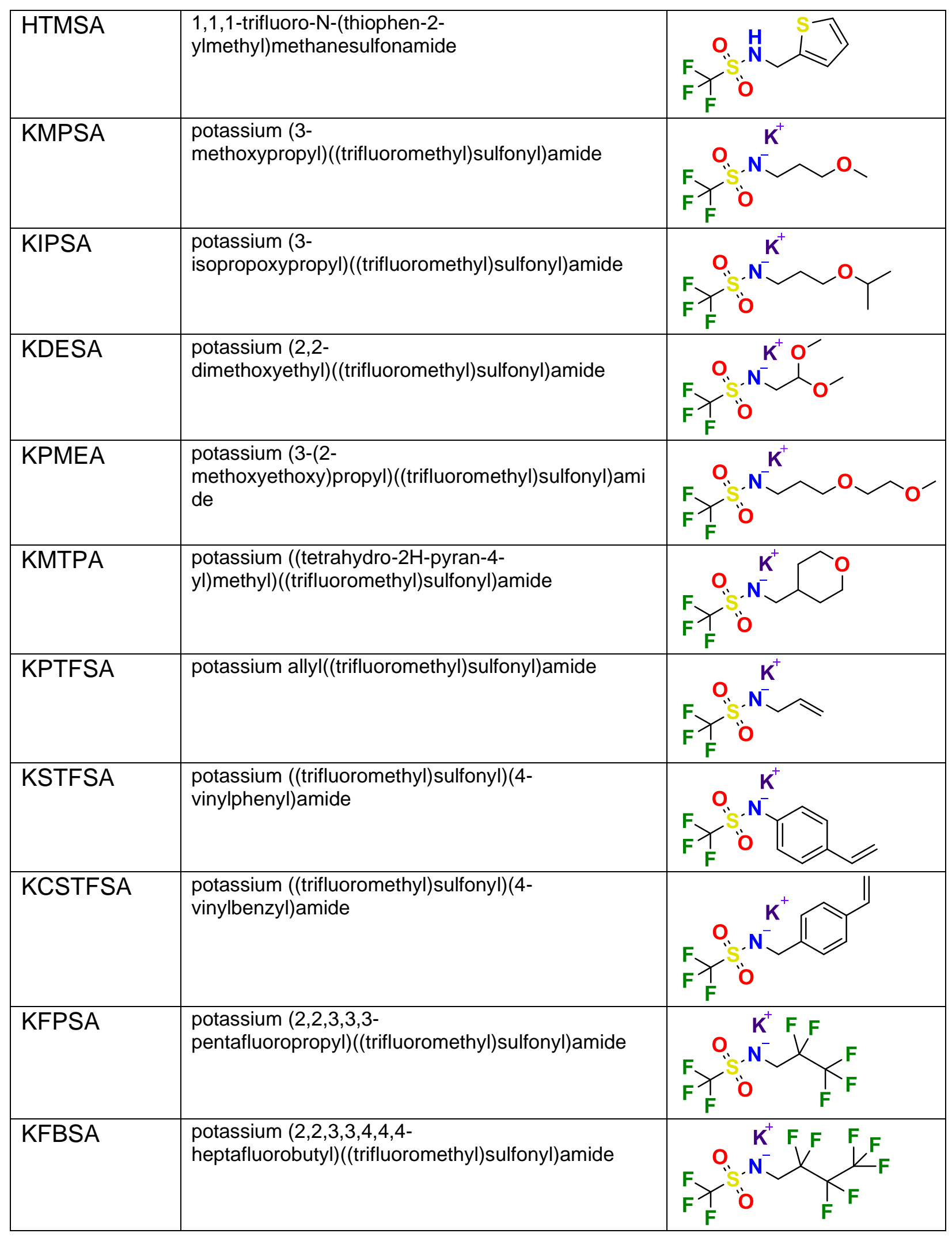




\begin{tabular}{|l|l|l|}
\hline KTMSA & $\begin{array}{l}\text { potassium (thiophen-2- } \\
\text { ylmethyl)((trifluoromethyl)sulfonyl)amide }\end{array}$
\end{tabular}

Table S1. List of sulfonamide acids and potassium salts synthesized, their full names and structures 
NMR Abbreviations $-\mathrm{s}=$ singlet $\mathrm{d}=$ doublet $\mathrm{t}=$ triplet $\mathrm{q}=$ quartet $\mathrm{p}=$ pentet $\mathrm{m}=$ multiplet NMR of Sulfonamide Acids

Figure S1. HMPSA
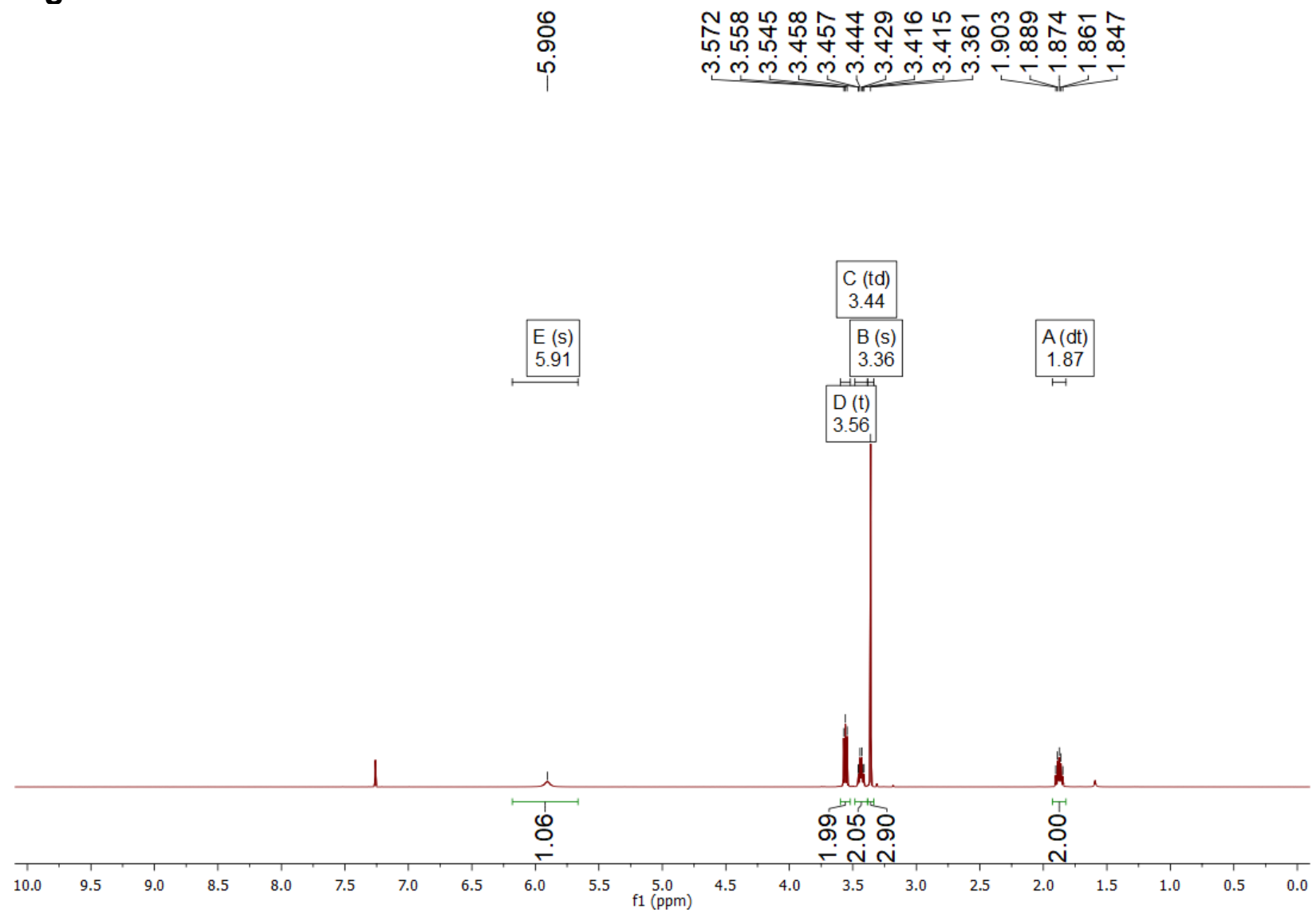

(a) ${ }^{1} \mathrm{H}$ NMR $\left(400 \mathrm{MHz}, \mathrm{CDCl}_{3}\right) \delta 5.91(\mathrm{~s}, 1 \mathrm{H}), 3.56$ (t, $\left.J=5.2 \mathrm{~Hz}, 2 \mathrm{H}\right), 3.44$ (td, $J=5.9$, $0.6 \mathrm{~Hz}, 2 \mathrm{H}), 3.36(\mathrm{~s}, 3 \mathrm{H}), 1.87(\mathrm{dt}, J=11.0,5.7 \mathrm{~Hz}, 2 \mathrm{H})$. Yield $76 \%$ 
$\underset{\infty}{\infty}$

$A(s)$
-78.68

$-78.68$

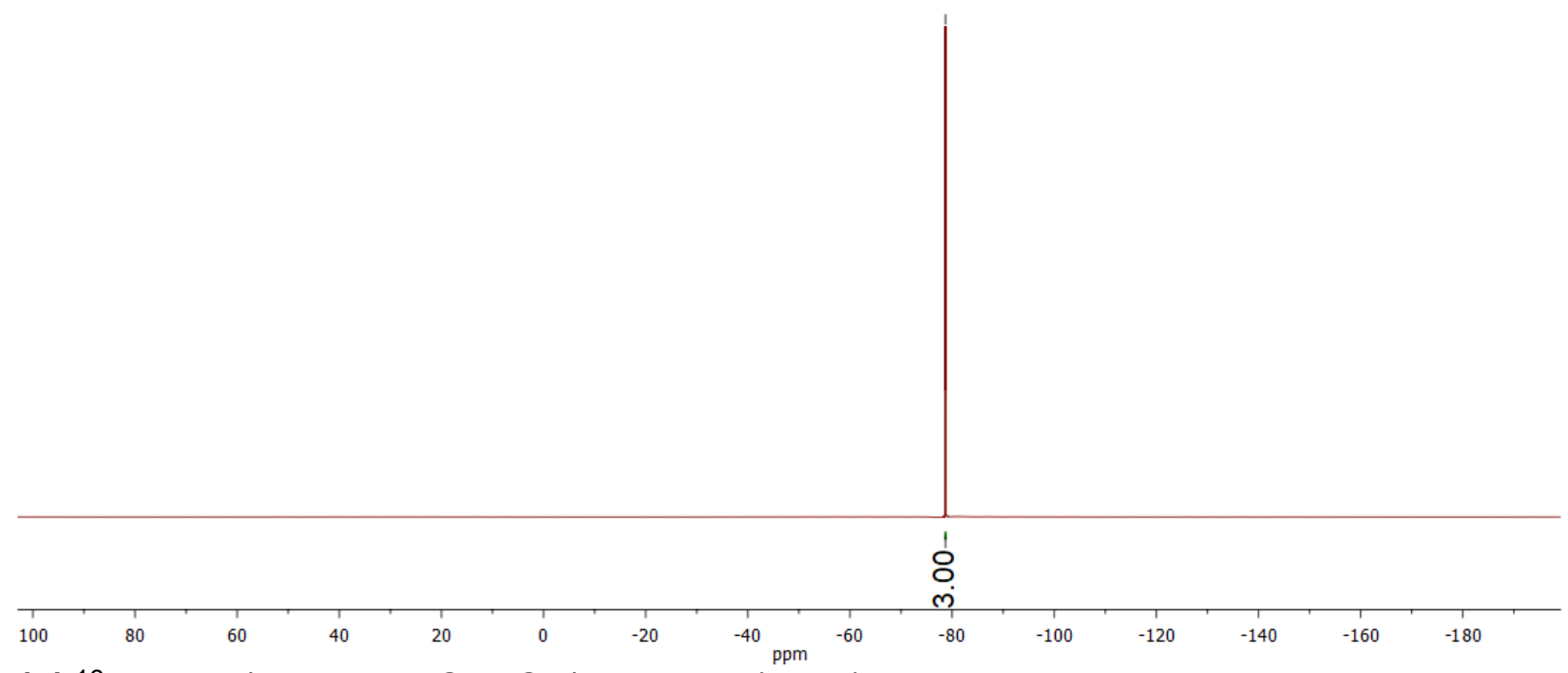

(b) ${ }^{19} \mathrm{~F}$ NMR (377 MHz, CD3CN) $\delta-78.68$ (s, 3F). 
Figure S2. HIPSA

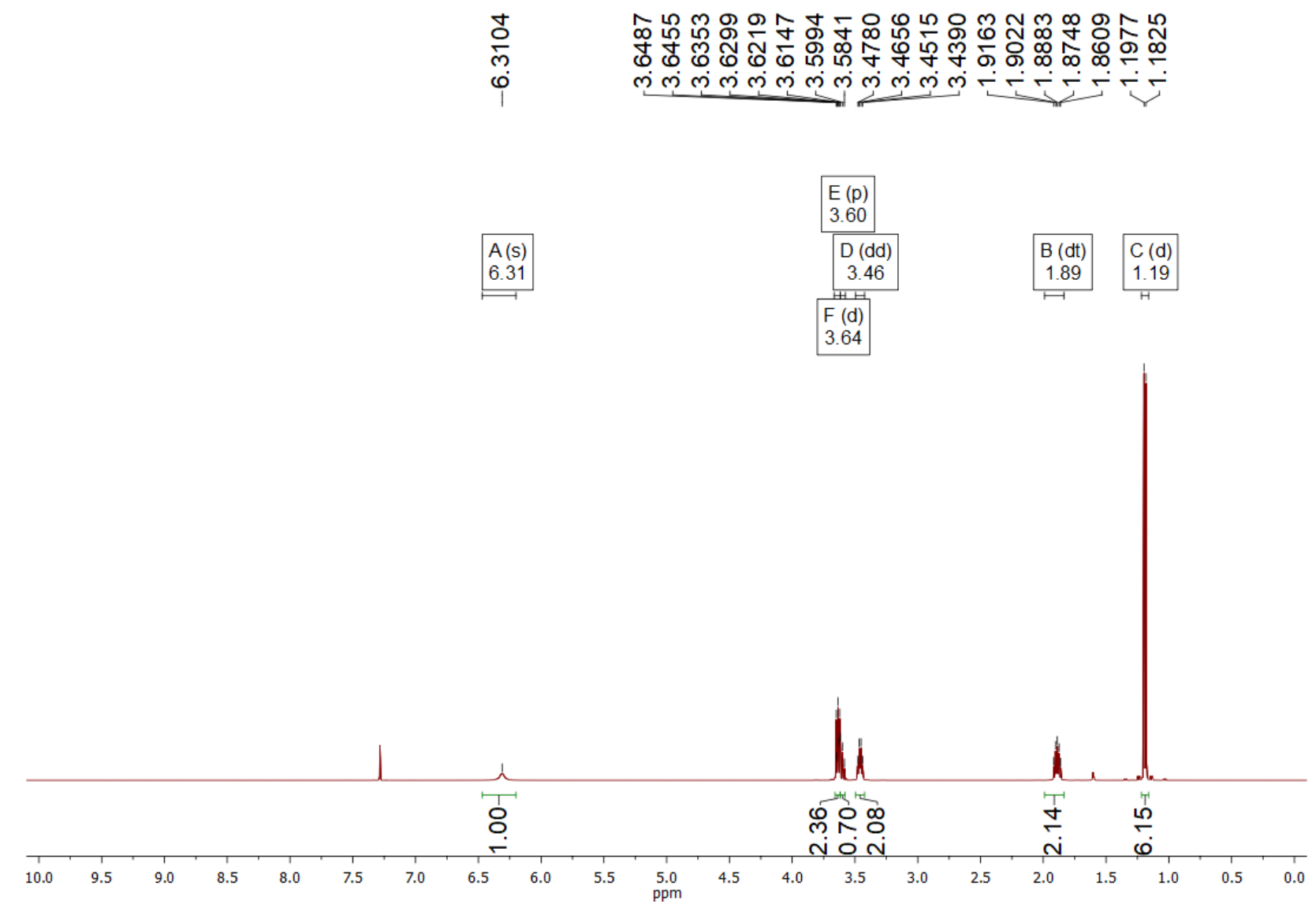

(a) ${ }^{1} \mathrm{H}$ NMR (400 MHz, $\left.\mathrm{CDCl}_{3}\right) \delta 6.31(\mathrm{~s}, 1 \mathrm{H}), 3.64(\mathrm{~d}, J=5.4 \mathrm{~Hz}, 2 \mathrm{H}), 3.60(\mathrm{p}, J=6.1$ $\mathrm{Hz}, 2 \mathrm{H}$ ), 3.46 (dd, $J=10.6,5.0 \mathrm{~Hz}, 2 \mathrm{H}$ ), 1.89 (dt, $J=10.9,5.6 \mathrm{~Hz}, 2 \mathrm{H}), 1.19$ (d, $J=6.1$ $\mathrm{Hz}, 6 \mathrm{H})$. Yield: $79 \%$ 
กิ

A (s)
-77.39

$-77.39$

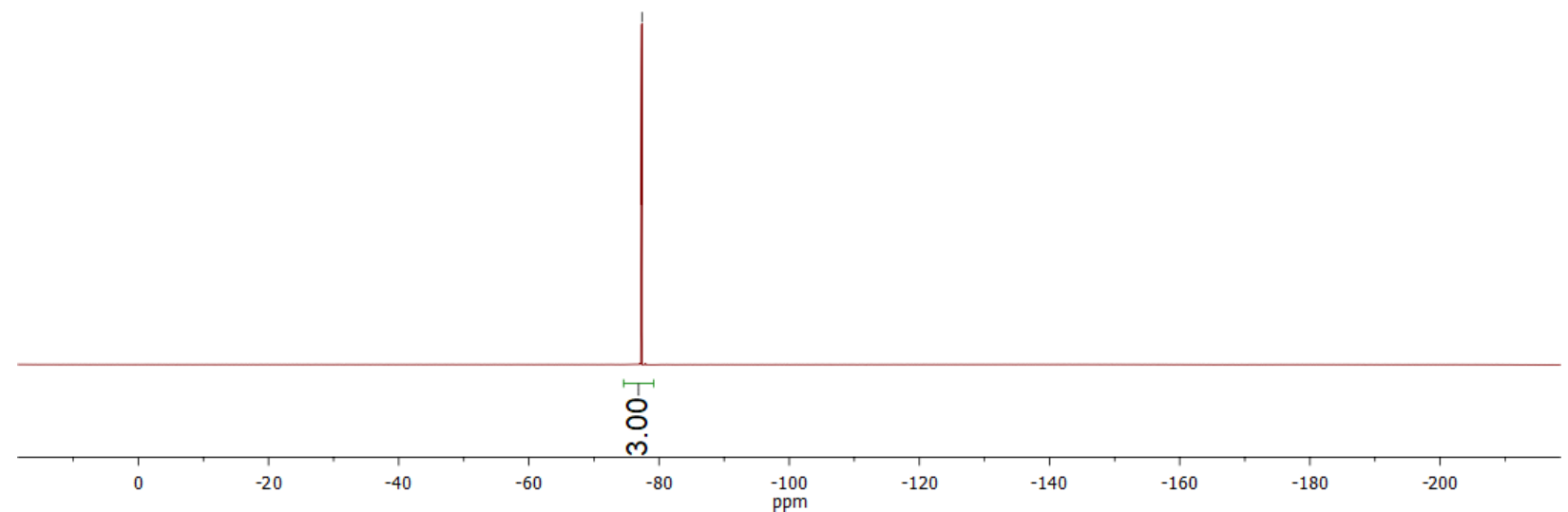

(b) ${ }^{19} \mathrm{~F}$ NMR (377 MHz, $\left.\mathrm{CDCl}_{3}\right) \delta-77.39$ (s, 3F). 
Figures S3. HDESA

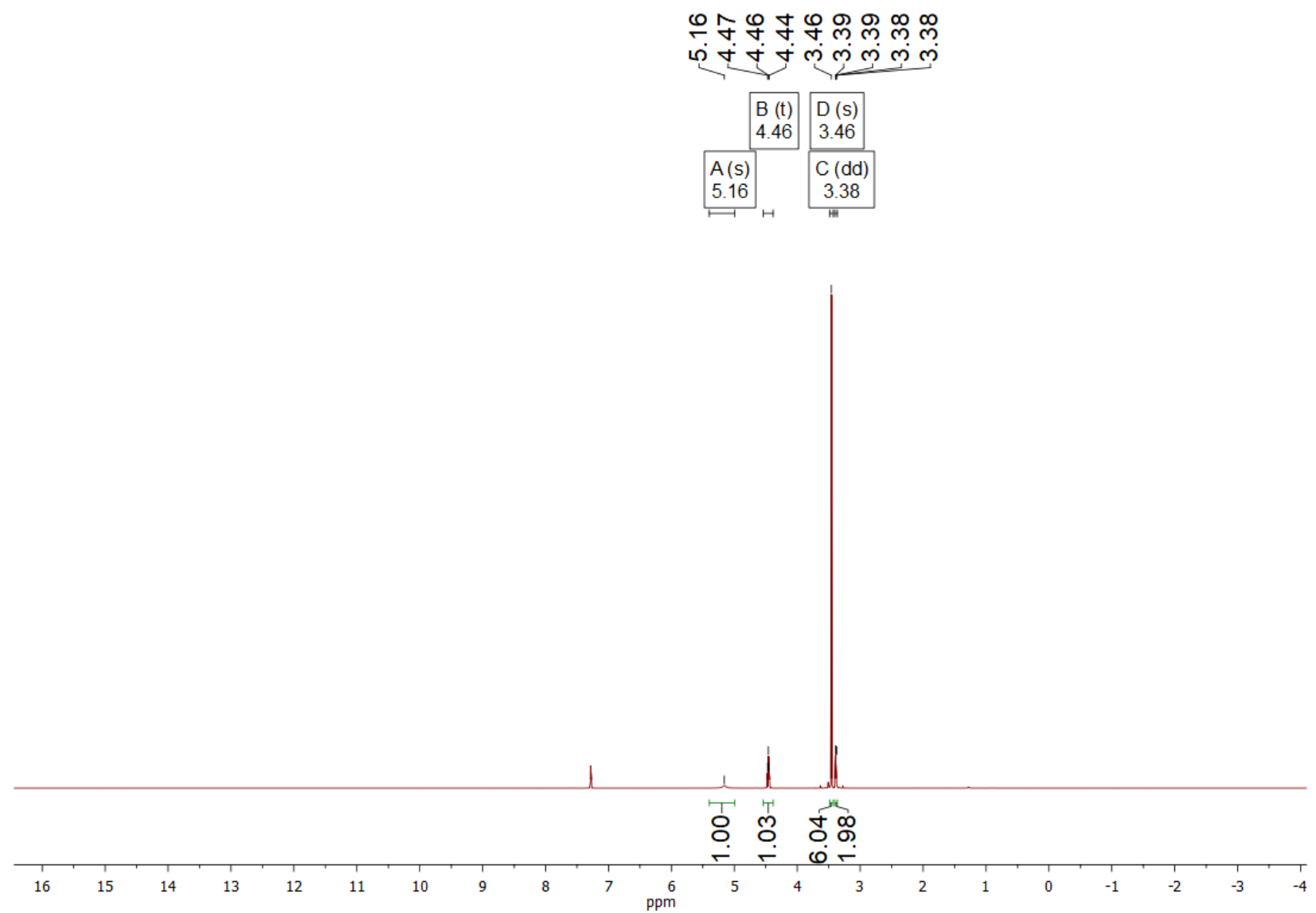

(a) ${ }^{1} \mathrm{H} \mathrm{NMR}\left(400 \mathrm{MHz}, \mathrm{CDCl}_{3}\right) \delta 5.16(\mathrm{~s}, 1 \mathrm{H}), 4.46(\mathrm{t}, J=5.3 \mathrm{~Hz}, 1 \mathrm{H}), 3.46(\mathrm{~s}, 6 \mathrm{H}), 3.38$ (dd, $J=5.2,0.5 \mathrm{~Hz}, 2 \mathrm{H}$ ). Yield: $83 \%$ 
กิ

A (s)

$-77.51$

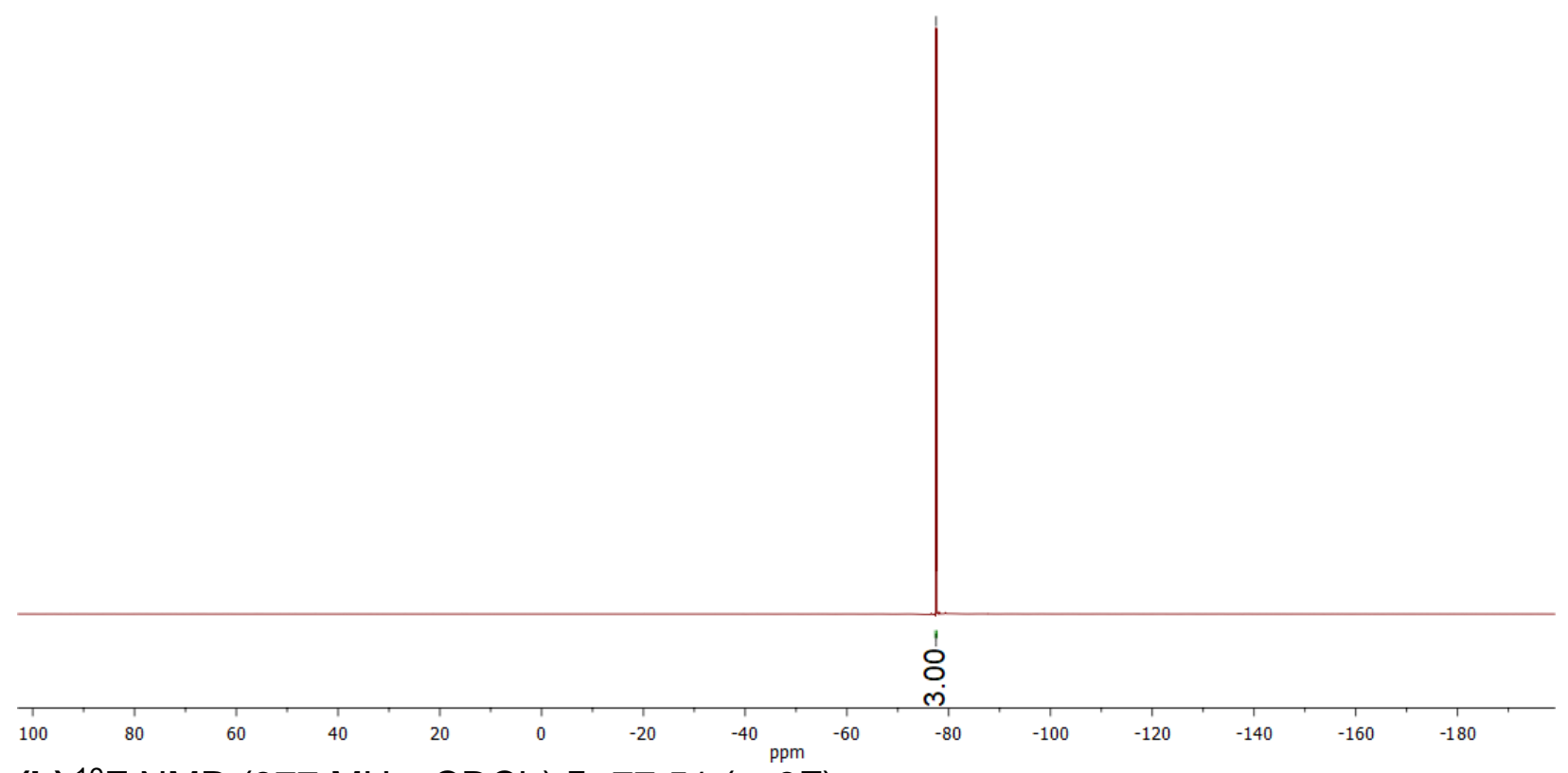

(b) ${ }^{19} \mathrm{~F}$ NMR (377 MHz, $\left.\mathrm{CDCl}_{3}\right) \delta-77.51$ (s, 3F). 


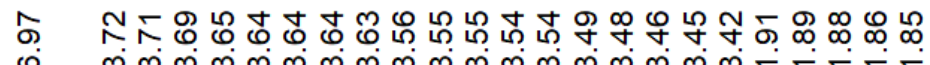

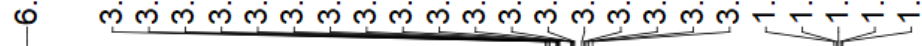

B (s)
6.97
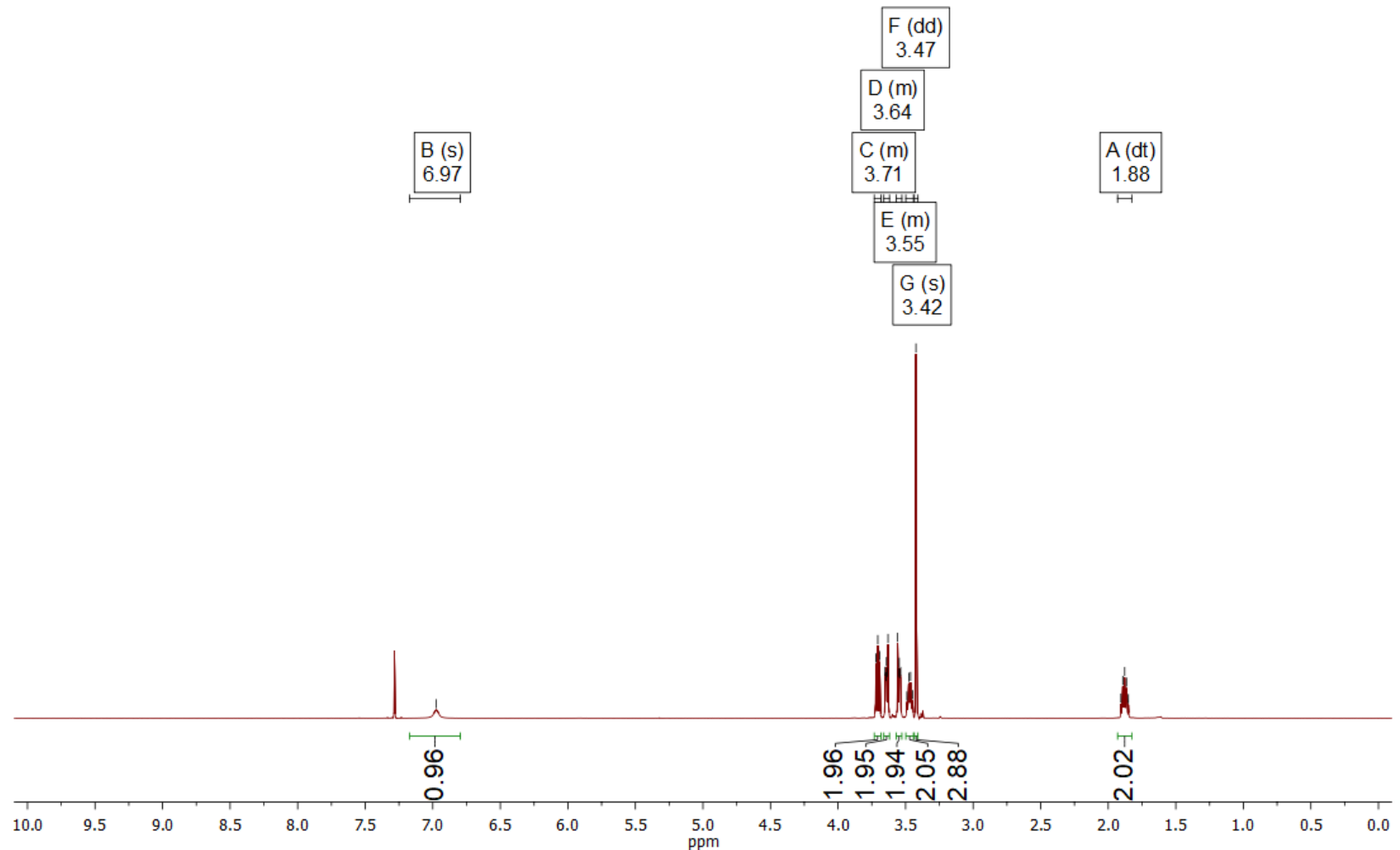

(a) ${ }^{1} \mathrm{H}$ NMR $\left(400 \mathrm{MHz}, \mathrm{CDCl}_{3}\right) \delta 6.97(\mathrm{~s}, 1 \mathrm{H}), 3.73-3.68(\mathrm{~m}, 2 \mathrm{H}), 3.66-3.62(\mathrm{~m}, 2 \mathrm{H})$, $3.57-3.53(\mathrm{~m}, 2 \mathrm{H}), 3.47$ (dd, $J=11.0,5.5 \mathrm{~Hz}, 2 \mathrm{H}), 3.42(\mathrm{~s}, 3 \mathrm{H}), 1.88(\mathrm{dt}, J=11.0,5.5$ $\mathrm{Hz}, 2 \mathrm{H})$. Yield: $72 \%$ 


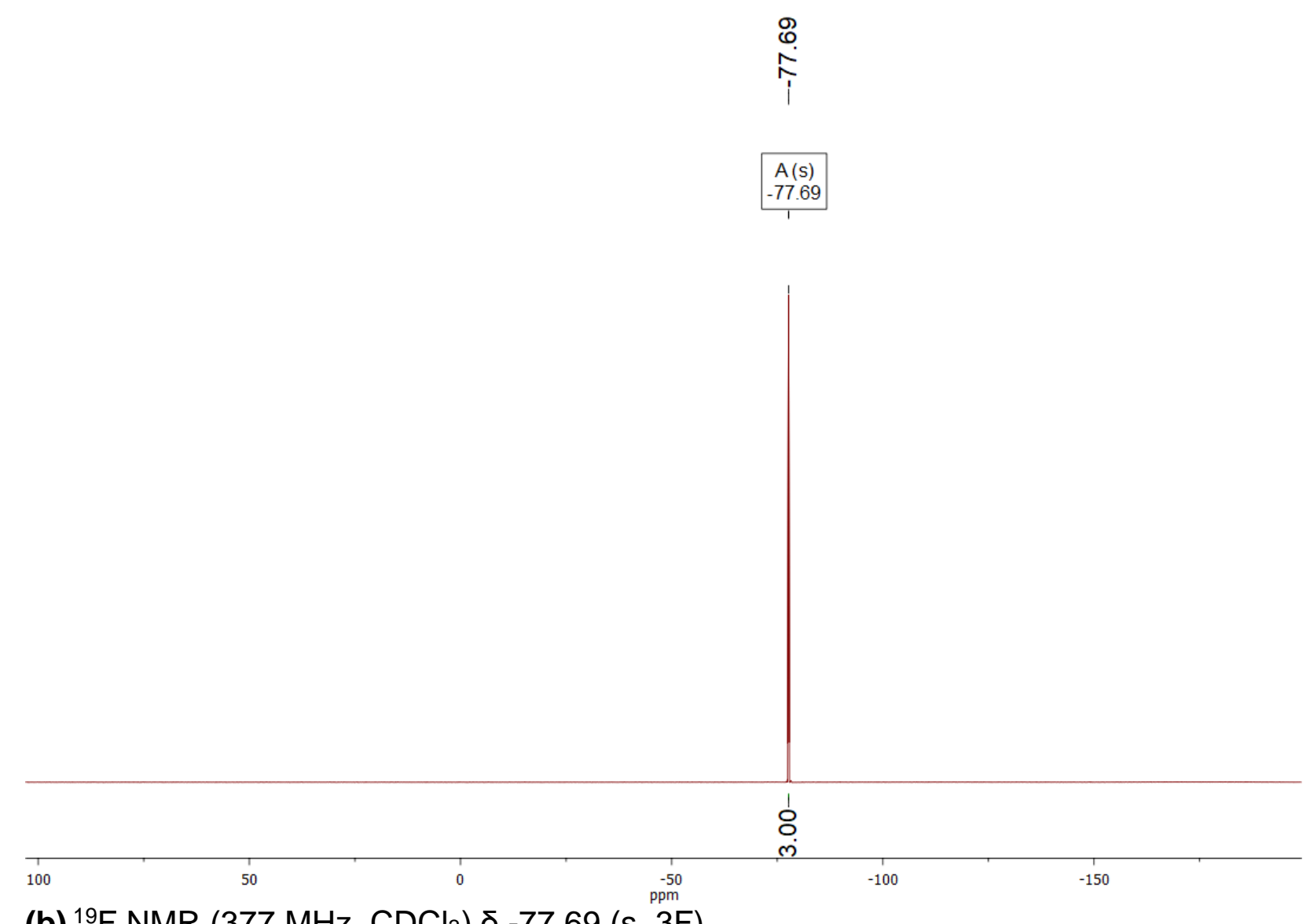

(b) ${ }^{19} \mathrm{~F} \mathrm{NMR}\left(377 \mathrm{MHz}, \mathrm{CDCl}_{3}\right) \delta-77.69$ (s, 3F). 
Figure S5. HMTPA

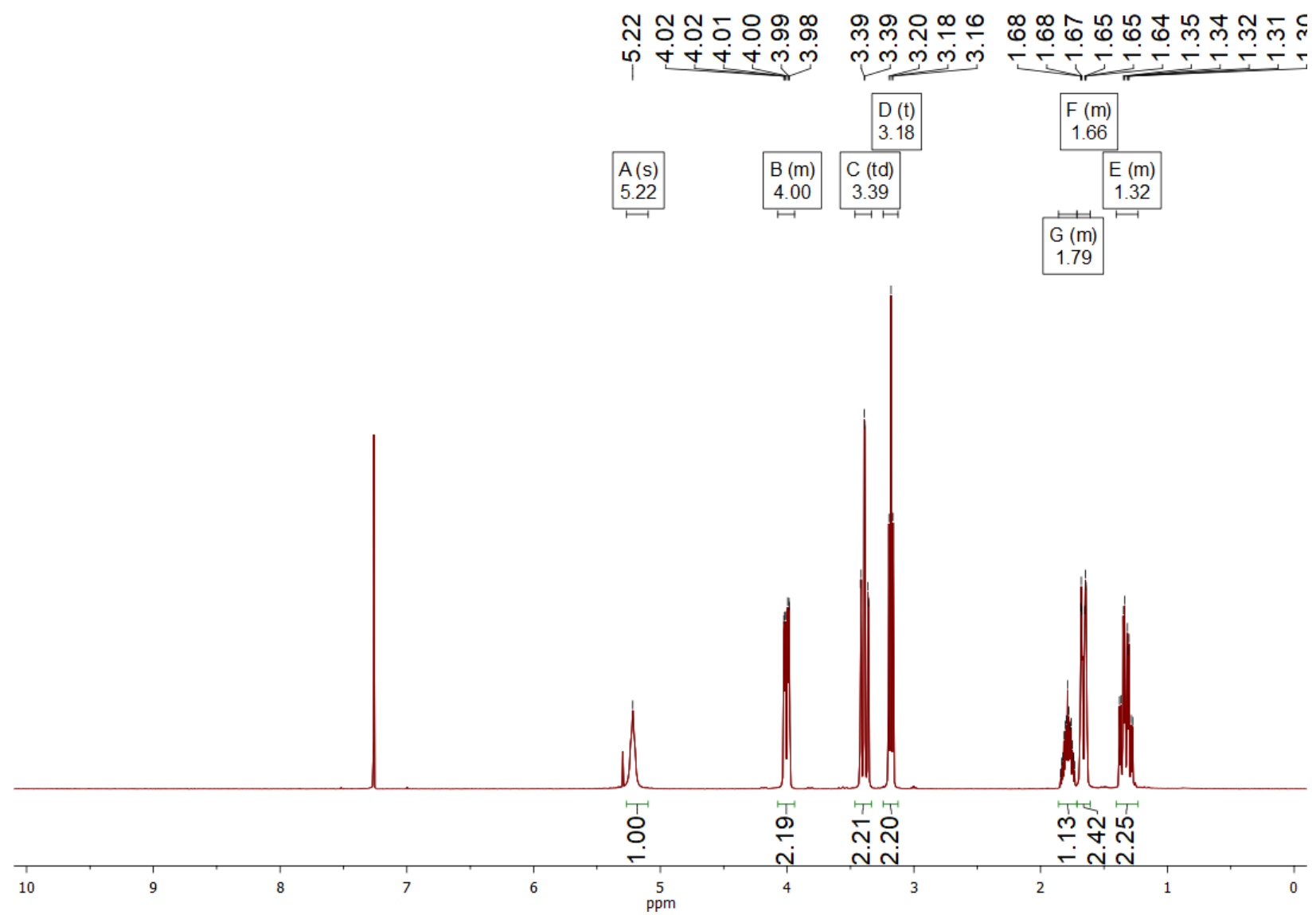

(a) ${ }^{1} \mathrm{H}$ NMR (400 MHz, $\mathrm{CDCl}_{3}$ ) $\delta 5.22(\mathrm{~s}, 1 \mathrm{H}), 4.07-3.94$ (m, 2H), 3.39 (td, $J=11.9,2.1$ $\mathrm{Hz}, 2 \mathrm{H}), 3.18(\mathrm{t}, J=6.5 \mathrm{~Hz}, 2 \mathrm{H}), 1.86-1.72(\mathrm{~m}, 1 \mathrm{H}), 1.71-1.61(\mathrm{~m}, 2 \mathrm{H}), 1.40-1.23$ (m, 2H). Yield: $85 \%$ 
$\stackrel{N}{i}$

A (s)

$-77.22$

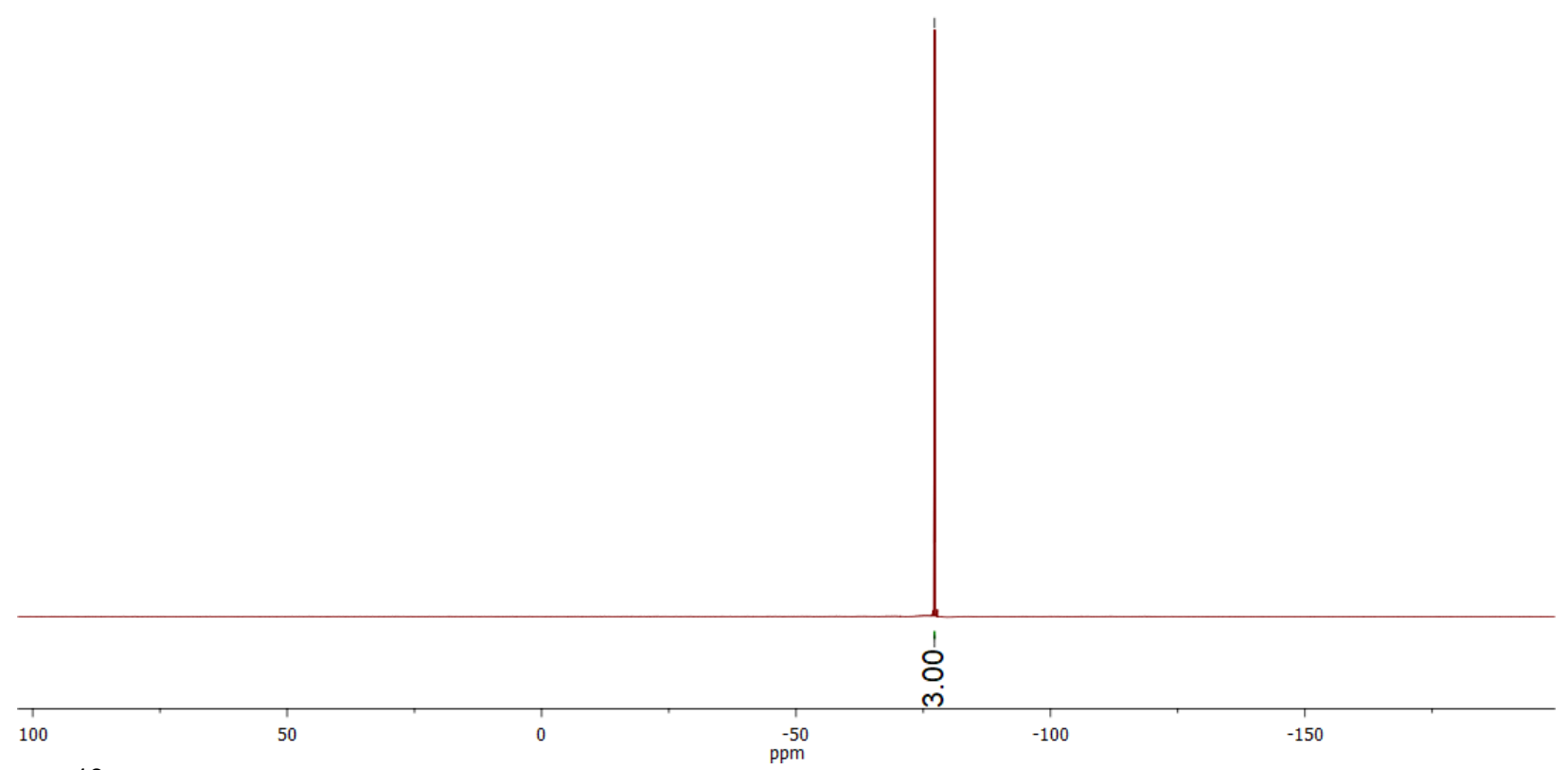

(b) $\left.{ }^{19} \mathrm{~F} \mathrm{NMR} \mathrm{(377} \mathrm{MHz,} \mathrm{CDCl}_{3}\right) \delta-77.22(\mathrm{~s}, 3 \mathrm{~F})$. 
Figure S6. HPTFSA

ద

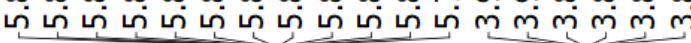

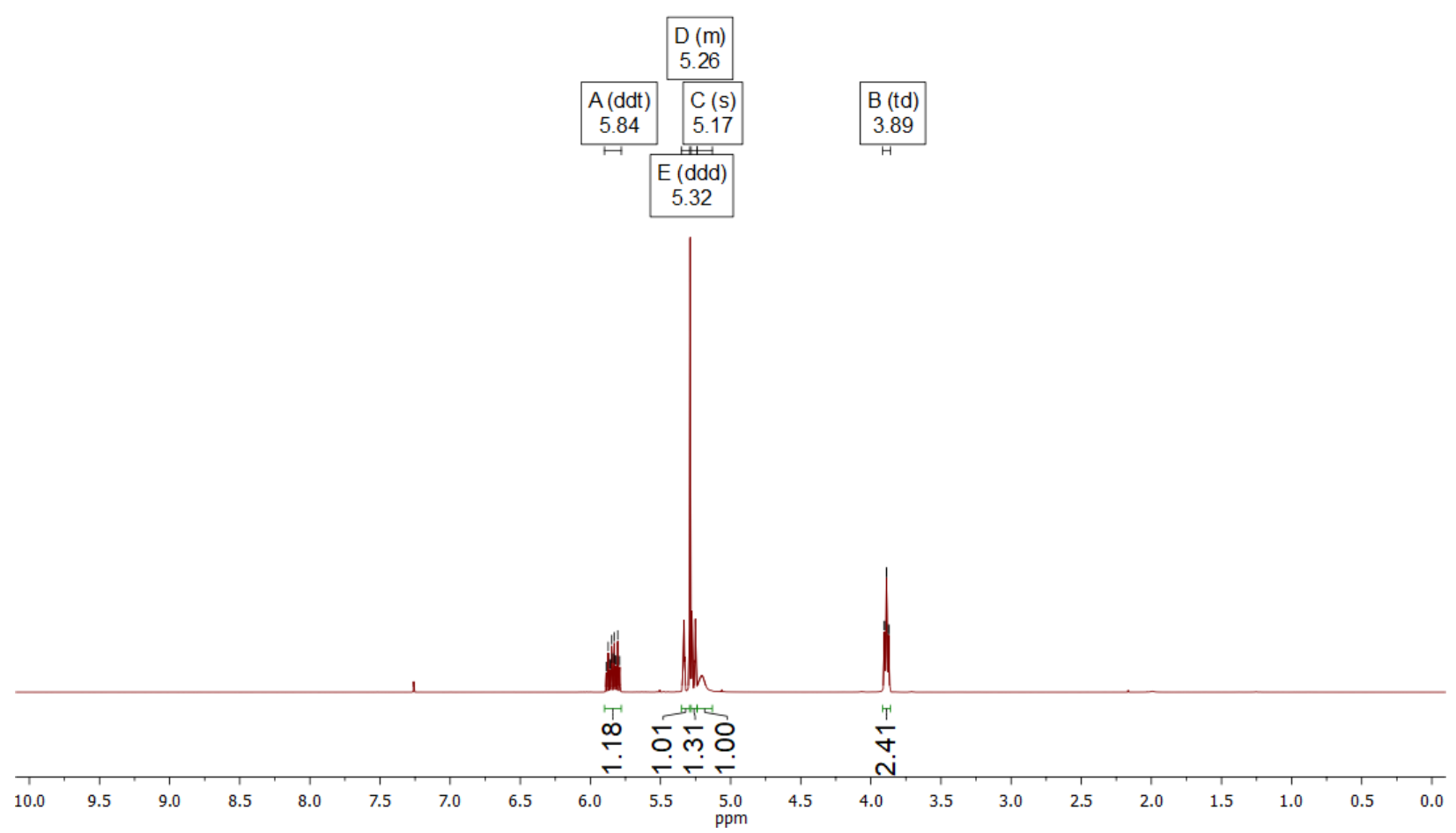

(a) ${ }^{1} \mathrm{H}$ NMR (400 MHz, $\mathrm{CDCl}_{3}$ ) $\delta 5.84$ (ddt, $\left.J=17.0,10.2,5.8 \mathrm{~Hz}, 1 \mathrm{H}\right), 5.32$ (ddd, $J=$ 14.7, 6.0, 1.2 Hz, 1H), $5.28-5.24(\mathrm{~m}, 1 \mathrm{H}), 5.17(\mathrm{~s}, 1 \mathrm{H}), 3.89$ (td, $J=5.9,0.6 \mathrm{~Hz}, 2 \mathrm{H})$. Yield: $78 \%$ 
กิ

A (s)
-77.58

$-77.58$

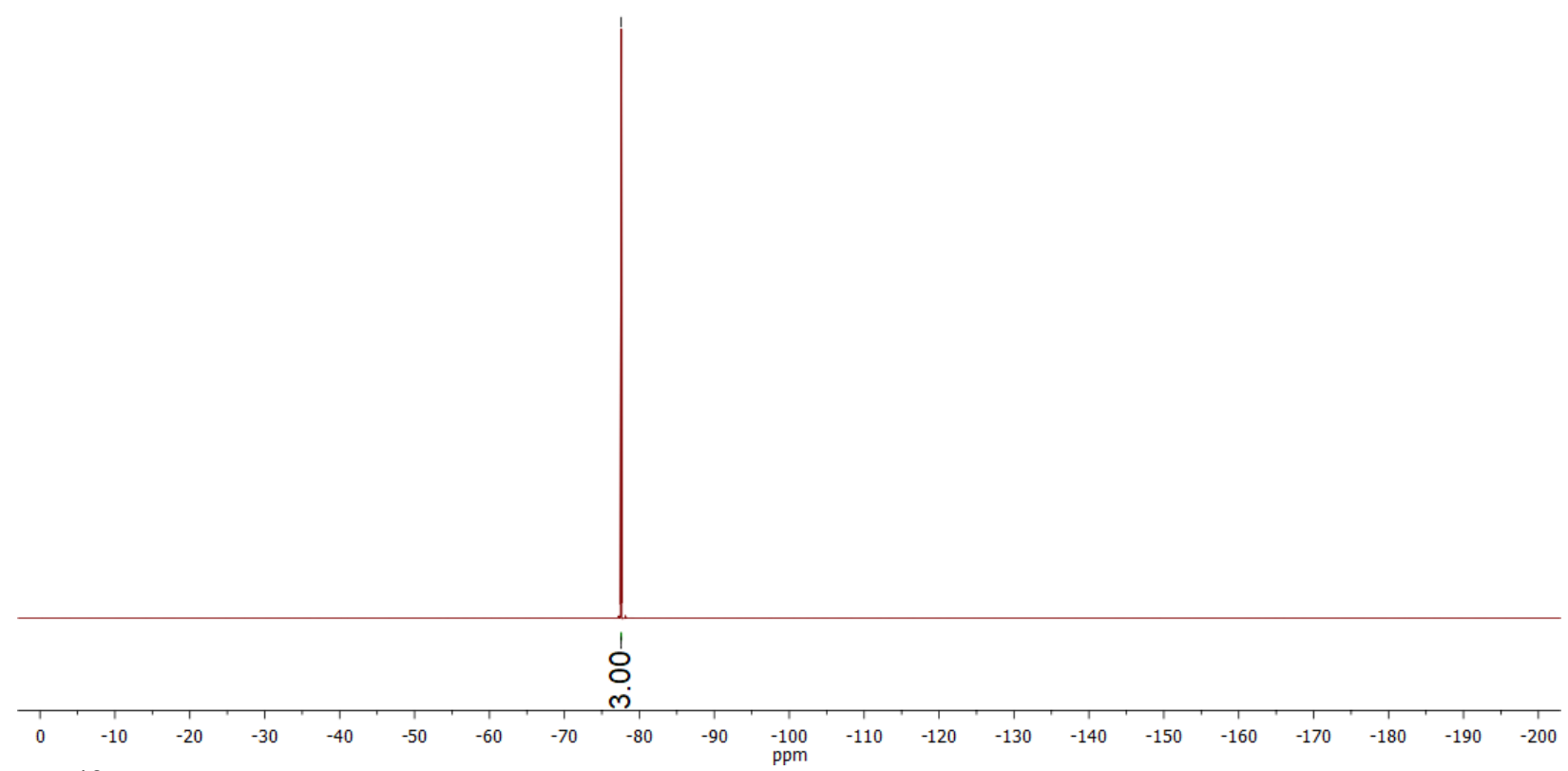

(b) $\left.{ }^{19} \mathrm{~F} \mathrm{NMR} \mathrm{(377} \mathrm{MHz,} \mathrm{CDCl}_{3}\right) \delta-77.58(\mathrm{~s}, 3 \mathrm{~F})$. 


\section{Figure S7. HSTFSA}

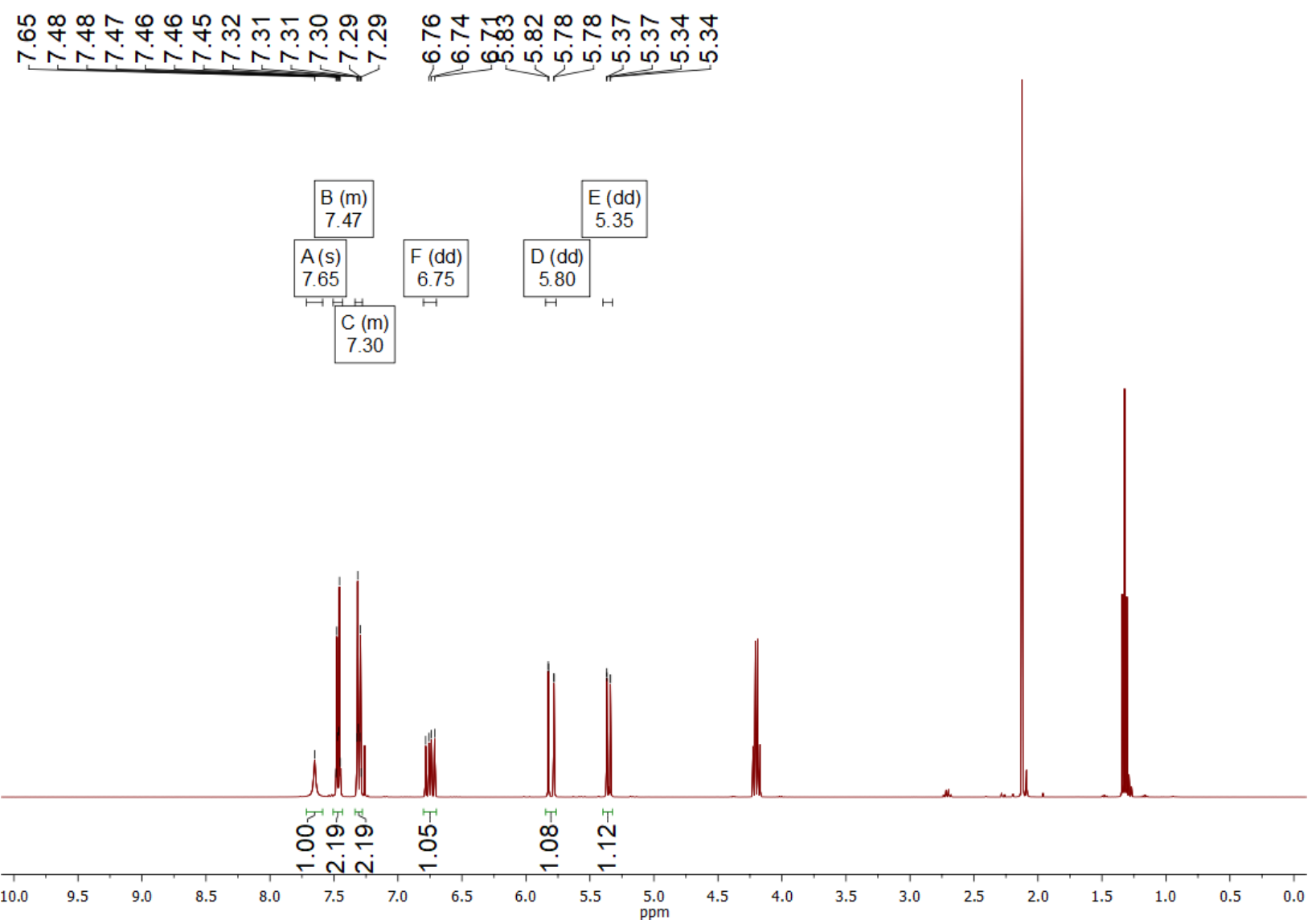

(a) ${ }^{1} \mathrm{H}$ NMR $\left(400 \mathrm{MHz}, \mathrm{CDCl}_{3}\right) \delta 7.65(\mathrm{~s}, 1 \mathrm{H}), 7.51-7.43(\mathrm{~m}, 2 \mathrm{H}), 7.34-7.28(\mathrm{~m}, 2 \mathrm{H})$, 6.75 (dd, $J=17.6,10.9 \mathrm{~Hz}, 1 \mathrm{H}$ ), 5.80 (dd, $J=17.6,0.7 \mathrm{~Hz}, 1 \mathrm{H}$ ), 5.35 (dd, $J=10.9,0.6$ $\mathrm{Hz}, 1 \mathrm{H})$. Yield: $76 \%$ 


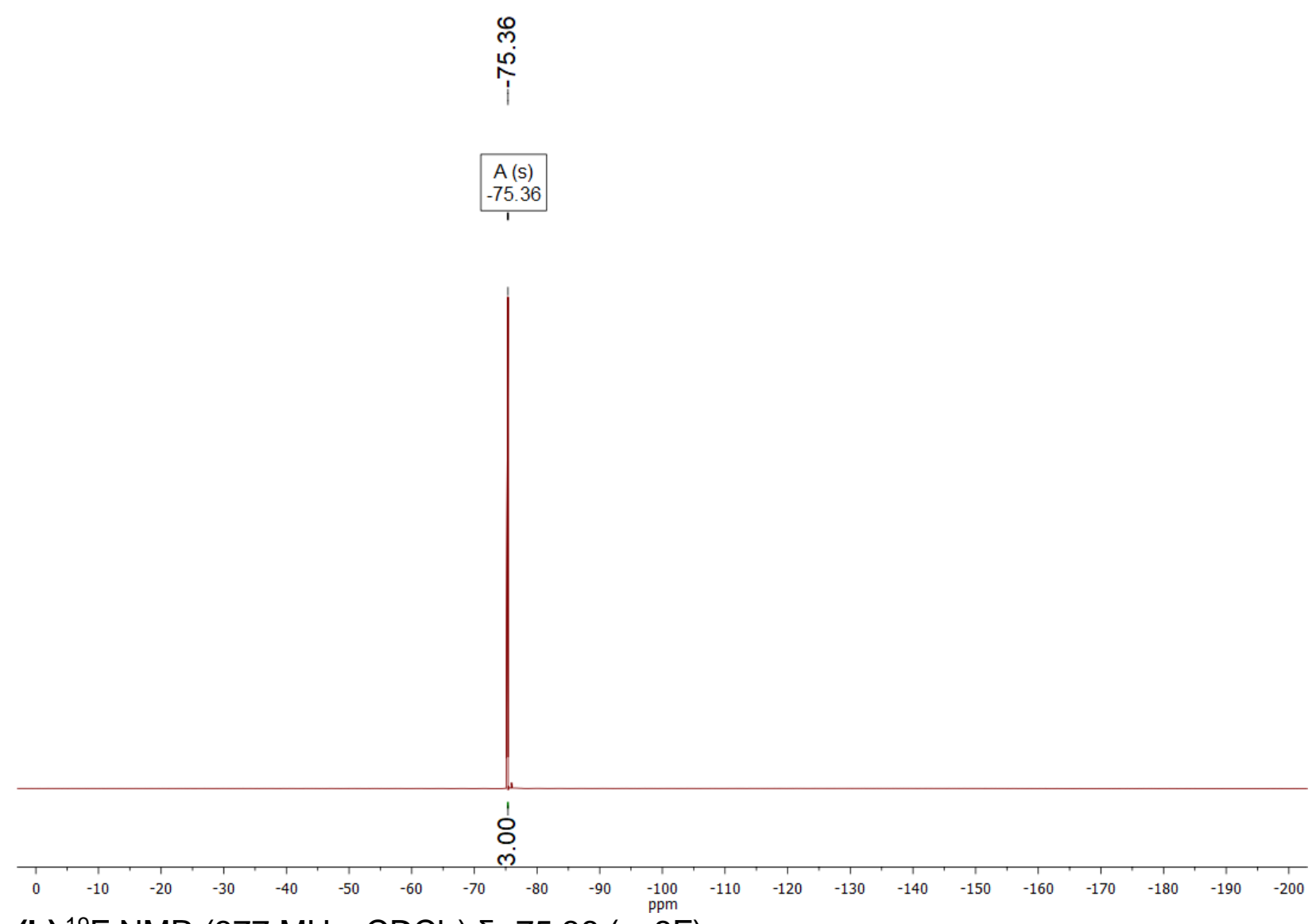

(b) $\left.{ }^{19} \mathrm{~F} \mathrm{NMR} \mathrm{(377} \mathrm{MHz,} \mathrm{CDCl}_{3}\right) \delta-75.36$ (s, 3F). 
Figure S8. HCSTFSA

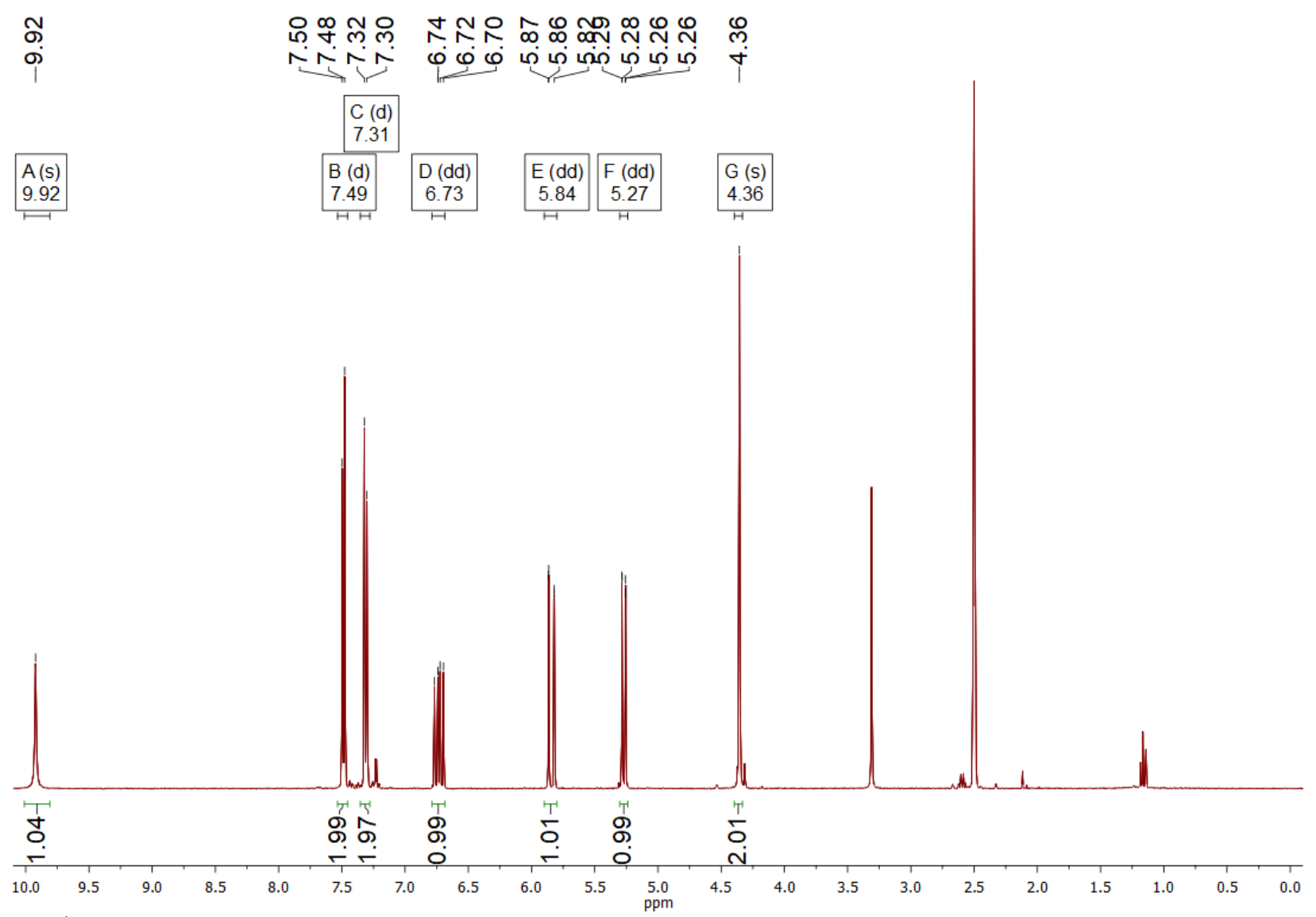

(a) ${ }^{1} \mathrm{H}$ NMR (400 MHz, DMSO) $\delta 9.92(\mathrm{~s}, 1 \mathrm{H}), 7.49(\mathrm{~d}, J=8.1 \mathrm{~Hz}, 2 \mathrm{H}), 7.31$ (d, $J=8.2$ $\mathrm{Hz}, 2 \mathrm{H}$ ), 6.73 (dd, $J=17.7,11.0 \mathrm{~Hz}, 1 \mathrm{H}$ ), 5.84 (dd, $J=17.7,1.0 \mathrm{~Hz}, 1 \mathrm{H}), 5.27$ (dd, $J=$ 10.9, $0.9 \mathrm{~Hz}, 1 \mathrm{H}), 4.36(\mathrm{~s}, 2 \mathrm{H})$. Yield: $73 \%$ 
ก̊

A (s)

$-77.35$

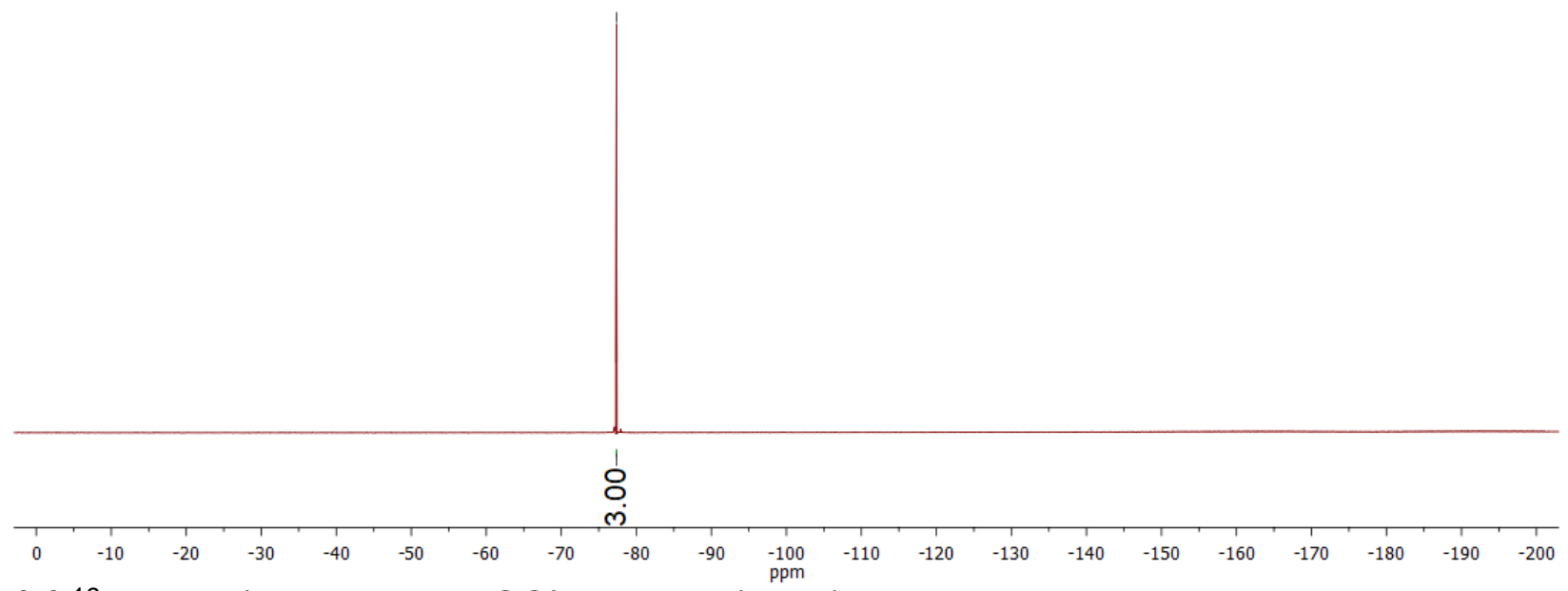

(b) ${ }^{19} \mathrm{~F}$ NMR (377 MHz, DMSO) $\delta-75.35$ (s, 3F). 
Figure S9. HFPSA

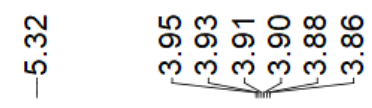

\begin{tabular}{|l|l}
\hline A (s) & $B(\mathrm{td})$ \\
5.32 & 3.90 \\
\hline
\end{tabular}

\begin{tabular}{|l|l|}
\hline 5.32 & 3.90 \\
\hline
\end{tabular}

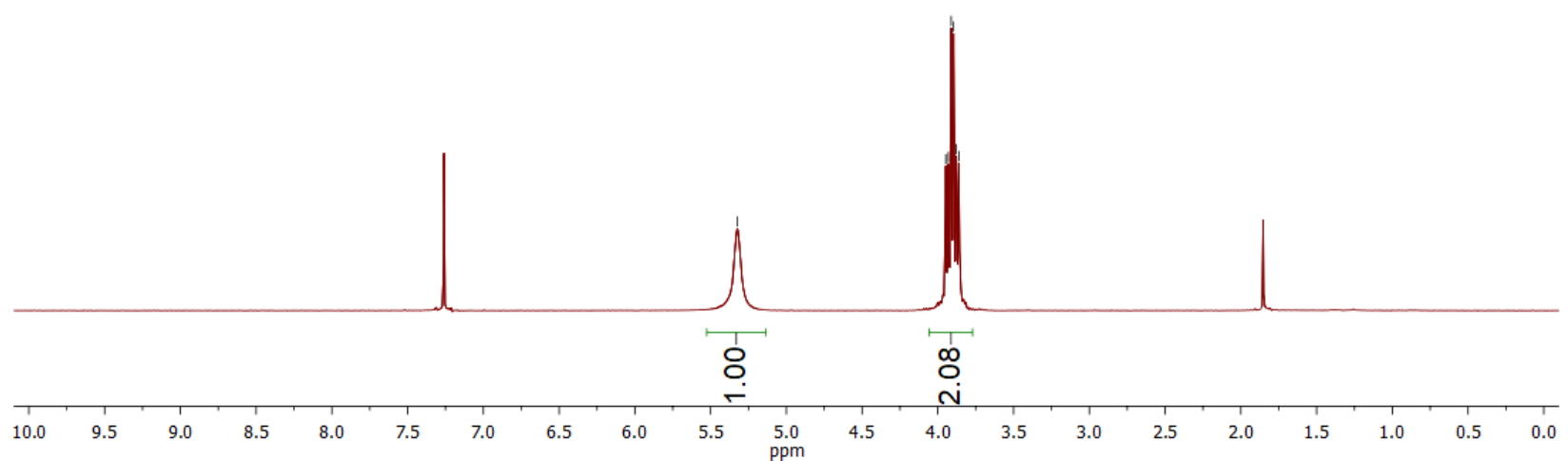

(a) ${ }^{1} \mathrm{H}$ NMR (400 MHz, $\left.\mathrm{CDCl}_{3}\right) \delta 5.32(\mathrm{~s}, 1 \mathrm{H}), 3.90$ (td, $J=14.0,6.5 \mathrm{~Hz}, 2 \mathrm{H}$ ). Yield: $79 \%$ 


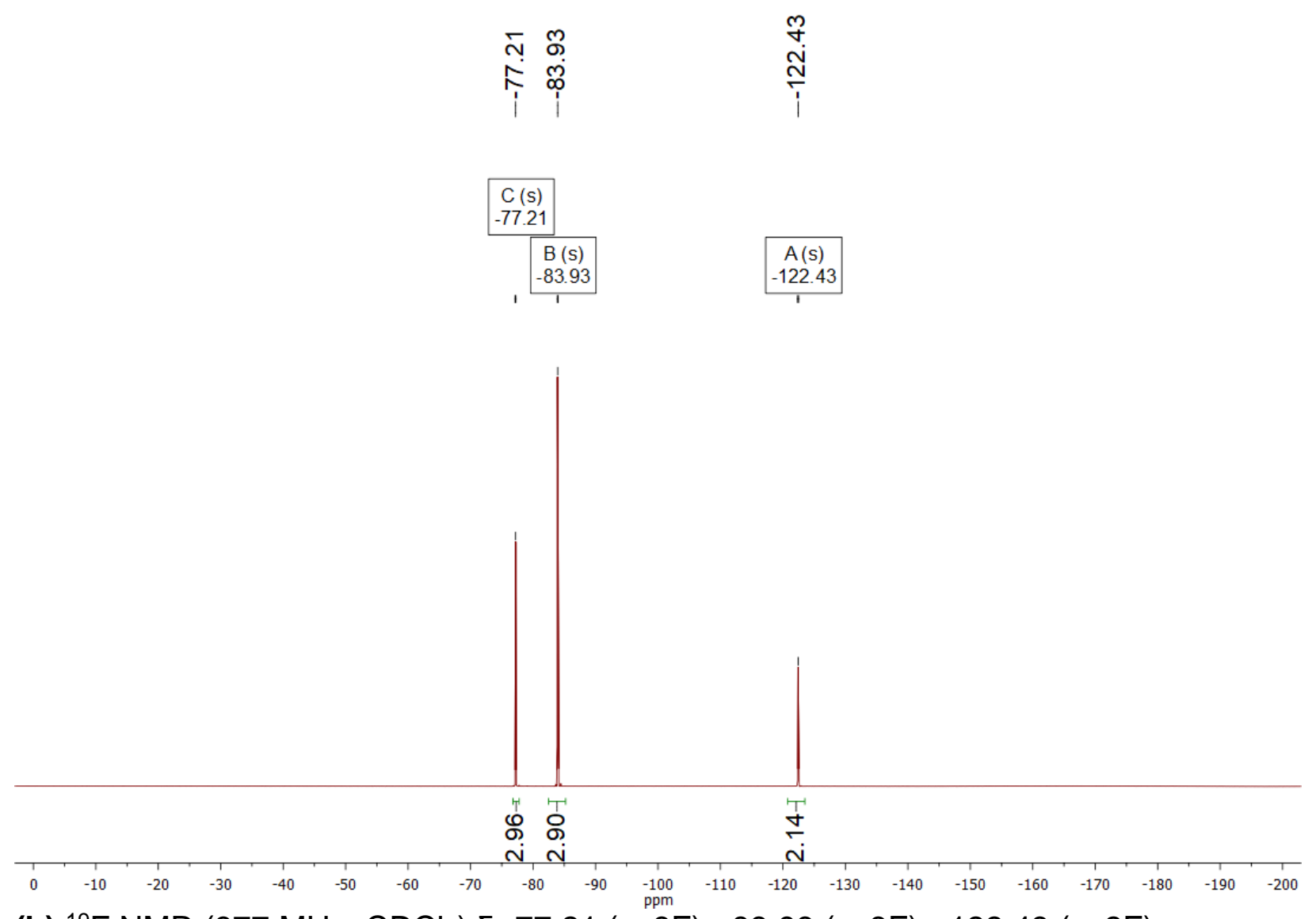

(b) ${ }^{19} \mathrm{~F} \mathrm{NMR}\left(377 \mathrm{MHz}, \mathrm{CDCl}_{3}\right) \delta-77.21$ (s, 3F), -83.93 (s, 3F), -122.43 (s, 2F). 
Figure S10. HFBSA

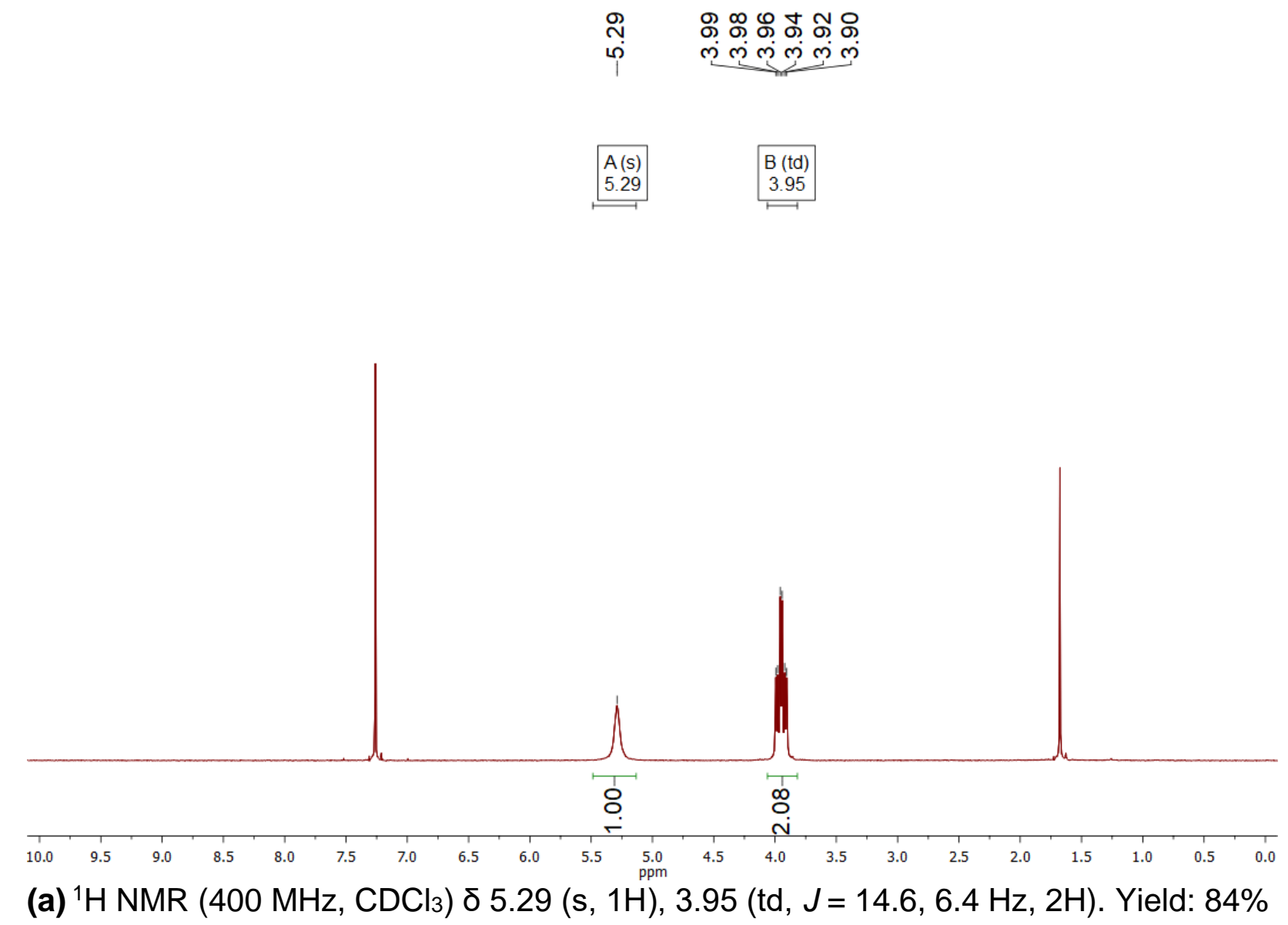




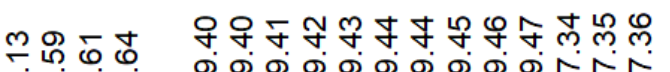

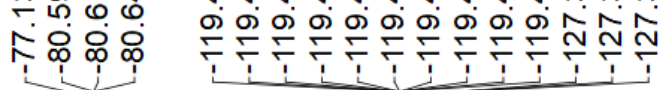

\begin{tabular}{|c|}
\hline $\mathrm{B}(\mathrm{t})$ \\
-80.61 \\
\hline $\mathrm{A}(\mathrm{s})$ \\
-77.13 \\
\hline $\mathrm{I}$
\end{tabular}
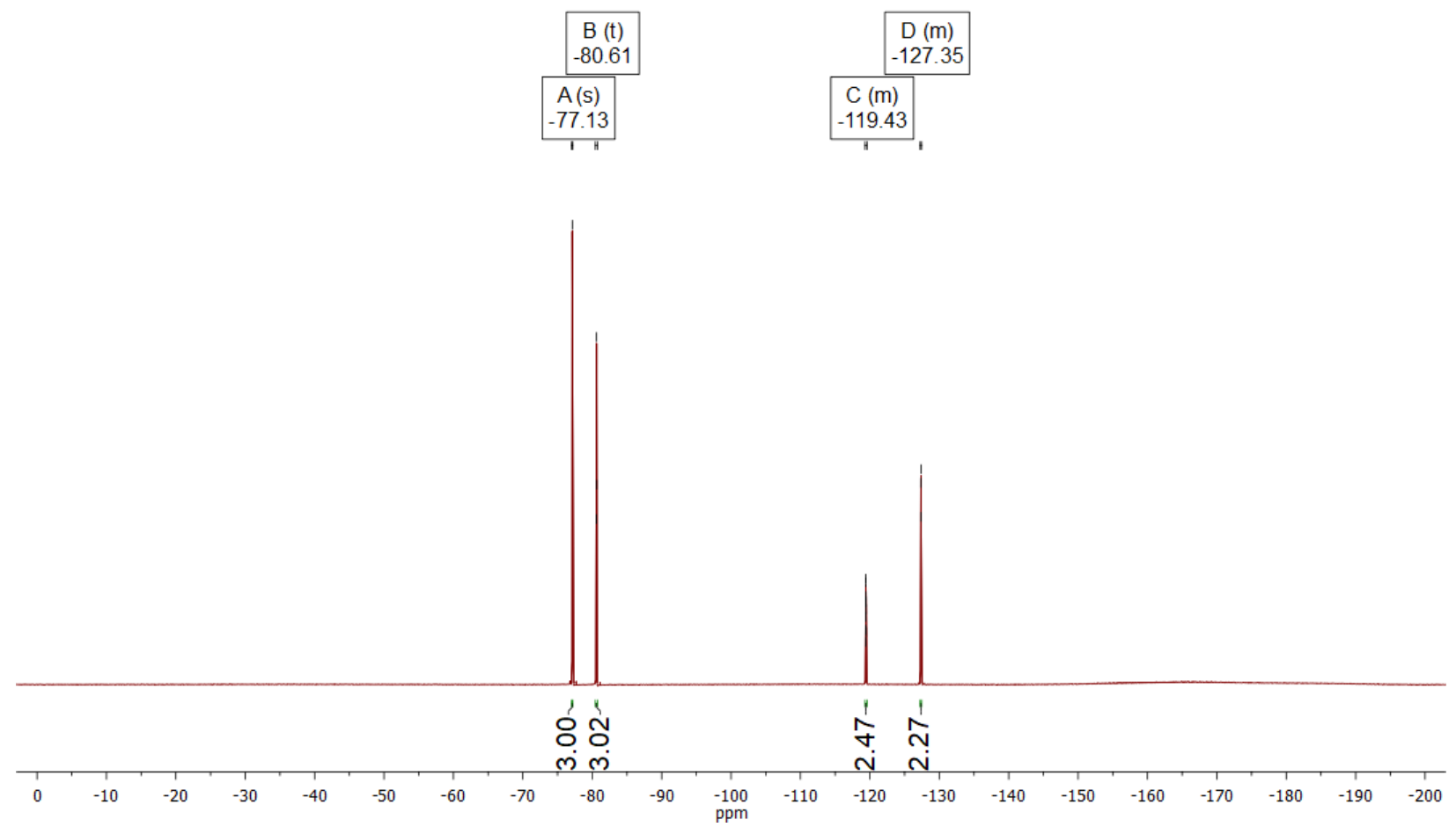

(b) ${ }^{19} \mathrm{~F}$ NMR (377 MHz, $\left.\mathrm{CDCl}_{3}\right) \delta-77.13(\mathrm{~s}, 3 \mathrm{~F}),-80.93(\mathrm{t}, J=9.2 \mathrm{~Hz}, 3 \mathrm{~F}),-119.43(\mathrm{~m}$, $2 \mathrm{~F}),-127.35(\mathrm{~m}, 2 \mathrm{~F})$. 


\section{Figure S11. HTMSA}

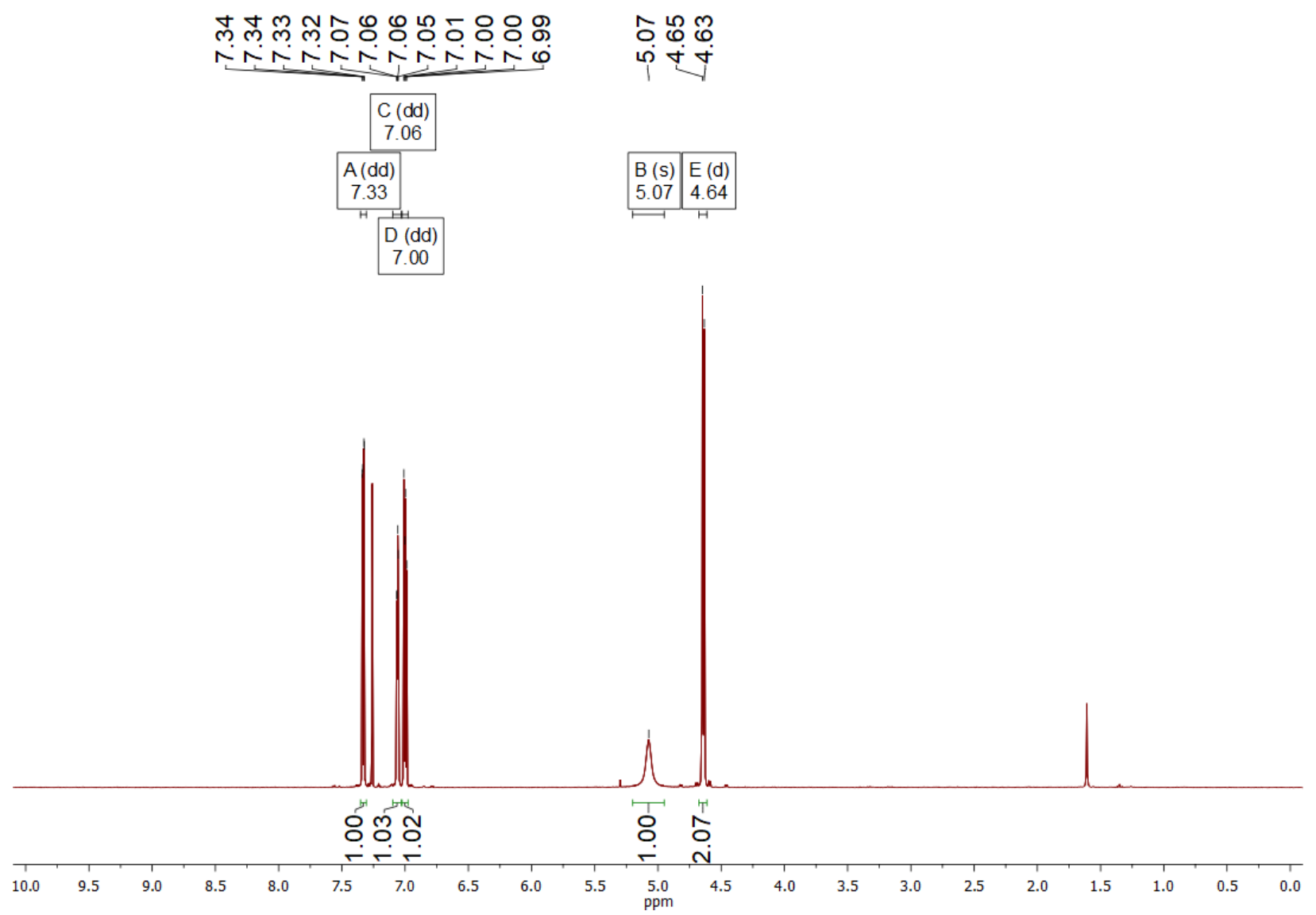

(a) ${ }^{1} \mathrm{H}$ NMR $\left(400 \mathrm{MHz}, \mathrm{CDCl}_{3}\right) \delta 7.33$ (dd, $\left.J=5.1,1.2 \mathrm{~Hz}, 1 \mathrm{H}\right), 7.06$ (dd, $J=3.5,1.1 \mathrm{~Hz}$, $1 \mathrm{H}$ ), 7.00 (dd, $J=5.1,3.5 \mathrm{~Hz}, 1 \mathrm{H}), 5.07(\mathrm{~s}, 1 \mathrm{H}), 4.64(\mathrm{~d}, J=5.7 \mathrm{~Hz}, 2 \mathrm{H})$. Yield: $82 \%$ 


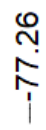

A (s)
-77.26

$-77.26$

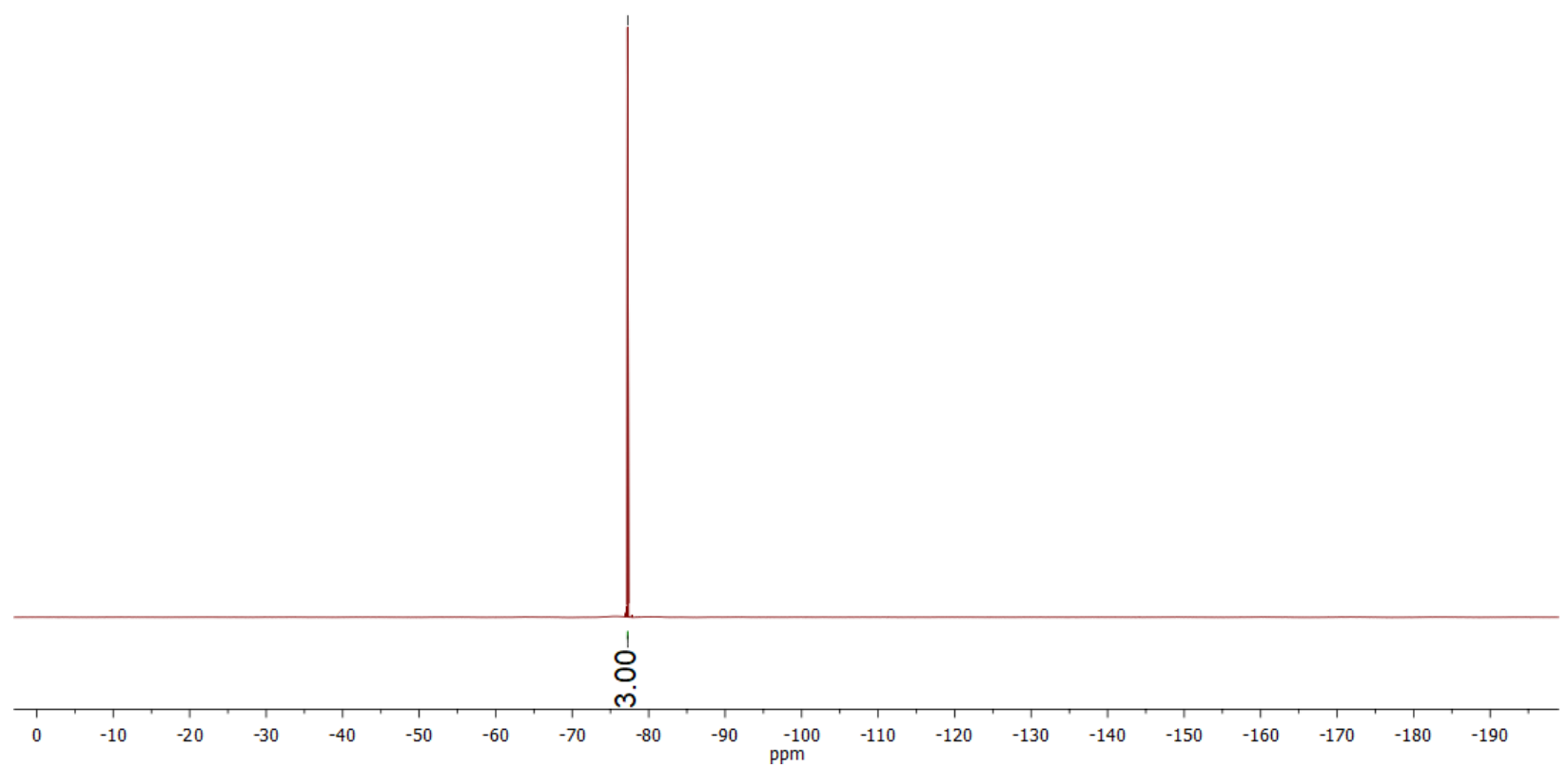

(b) ${ }^{19} \mathrm{~F} \mathrm{NMR} \mathrm{(377} \mathrm{MHz,} \mathrm{CDCl} 3$ ) $\delta-77.26$ (s, 3F). 
NMR of Potassium Salts

Figure S12. KMPSA

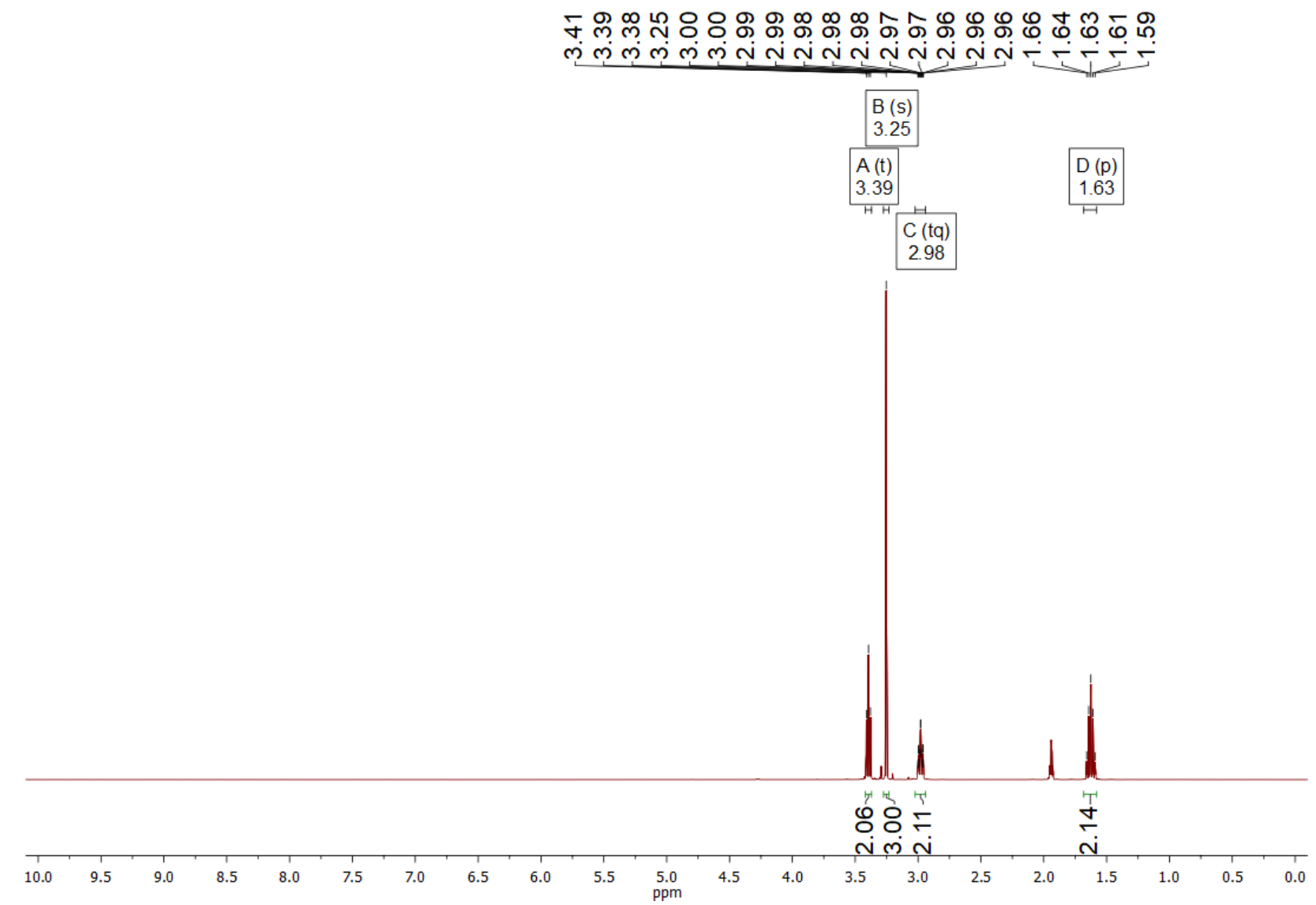

(a) ${ }^{1} \mathrm{H}$ NMR (400 MHz, $\mathrm{CD}_{3} \mathrm{CN}$ ) $\delta 3.39$ (t, $J=6.5 \mathrm{~Hz}, 2 \mathrm{H}$ ), 3.25 (s, 3H), 2.98 (tq, $J=6.8$, $1.4 \mathrm{~Hz}, 2 \mathrm{H}), 1.63$ (p, $J=6.7 \mathrm{~Hz}, 2 \mathrm{H}$ ). Yield: $88 \%$ 


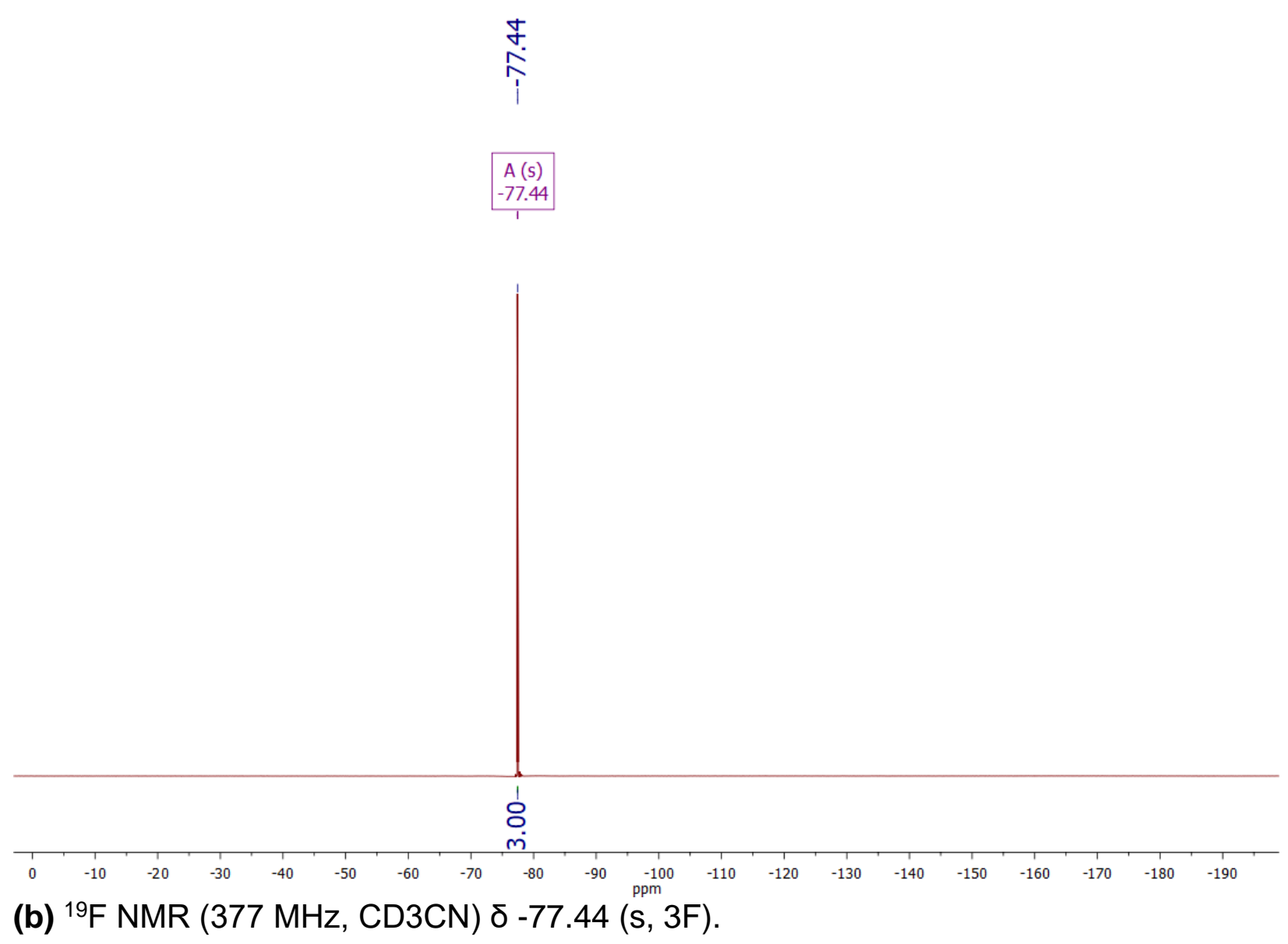


Figure S13. KIPSA

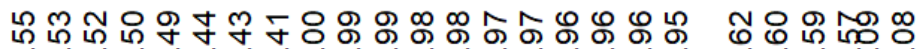

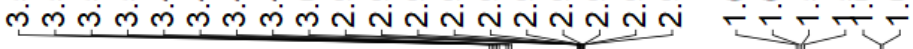

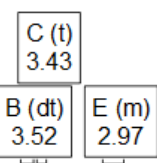

\begin{tabular}{|c|c|}
\hline$D(p)$ & $A(d)$ \\
1.59 & 1.09 \\
\hline
\end{tabular}

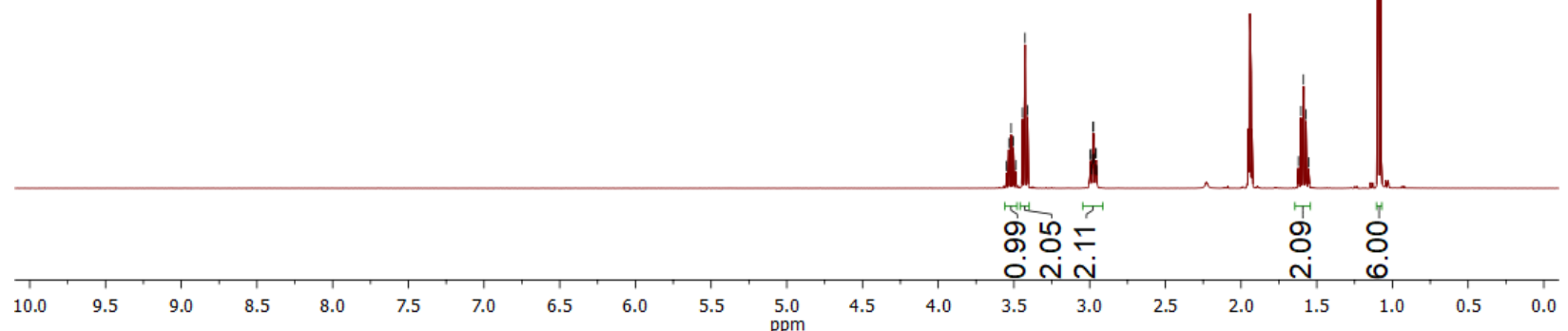

(a) ${ }^{1} \mathrm{H}$ NMR $\left(400 \mathrm{MHz}, \mathrm{CD}_{3} \mathrm{CN}\right) \delta 3.52(\mathrm{dt}, J=12.2,6.1 \mathrm{~Hz}, 1 \mathrm{H}), 3.43(\mathrm{t}, J=6.6 \mathrm{~Hz}, 2 \mathrm{H})$, $3.05-2.91(\mathrm{~m}, 2 \mathrm{H}), 1.59(\mathrm{p}, J=6.8 \mathrm{~Hz}, 2 \mathrm{H}), 1.09(\mathrm{~d}, J=6.1 \mathrm{~Hz}, 6 \mathrm{H})$. Yield: $90 \%$ 
กิ

A (s)
-77.34

$\frac{-77.34}{1}$

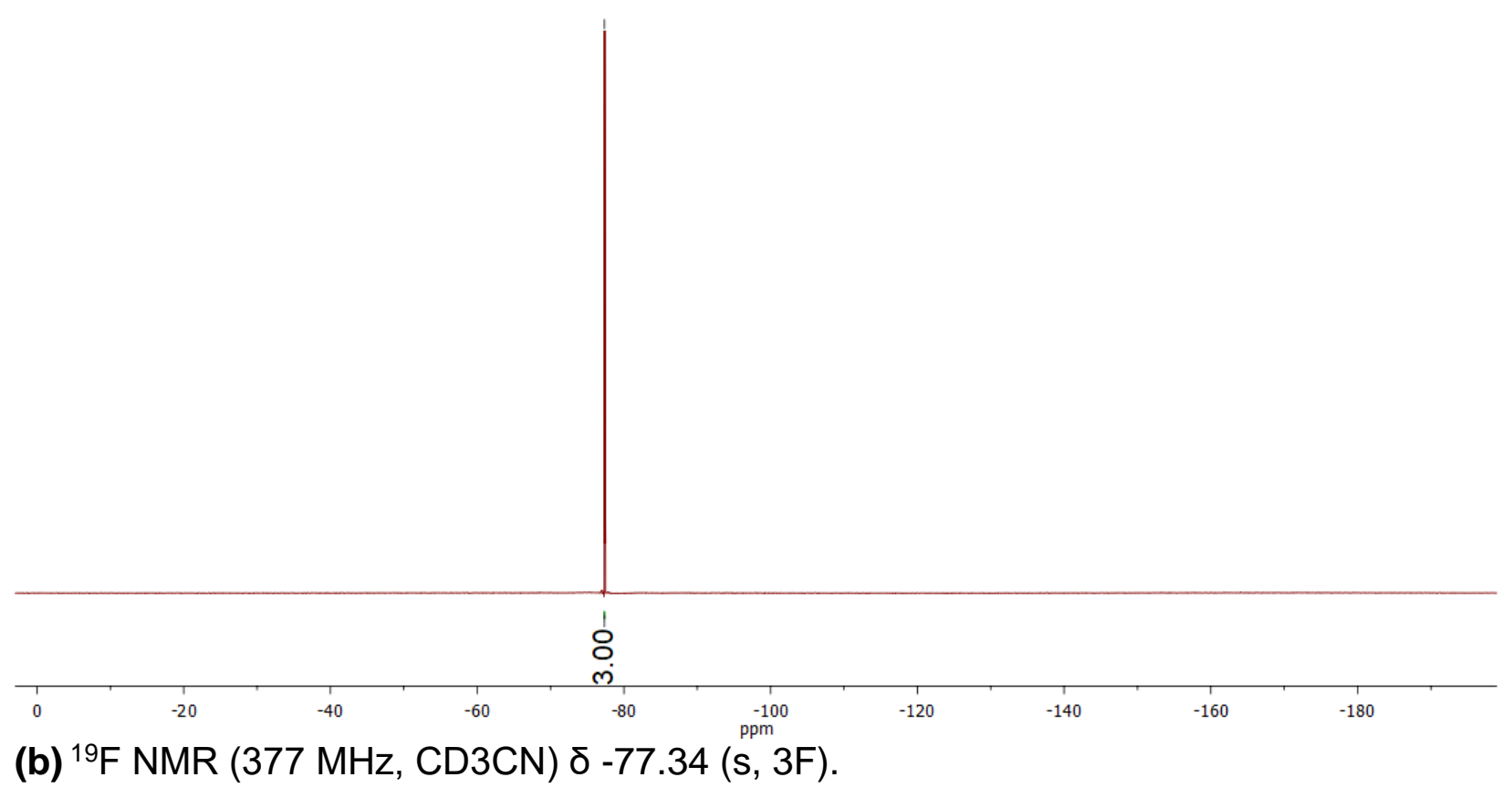


Figure S14. KDESA

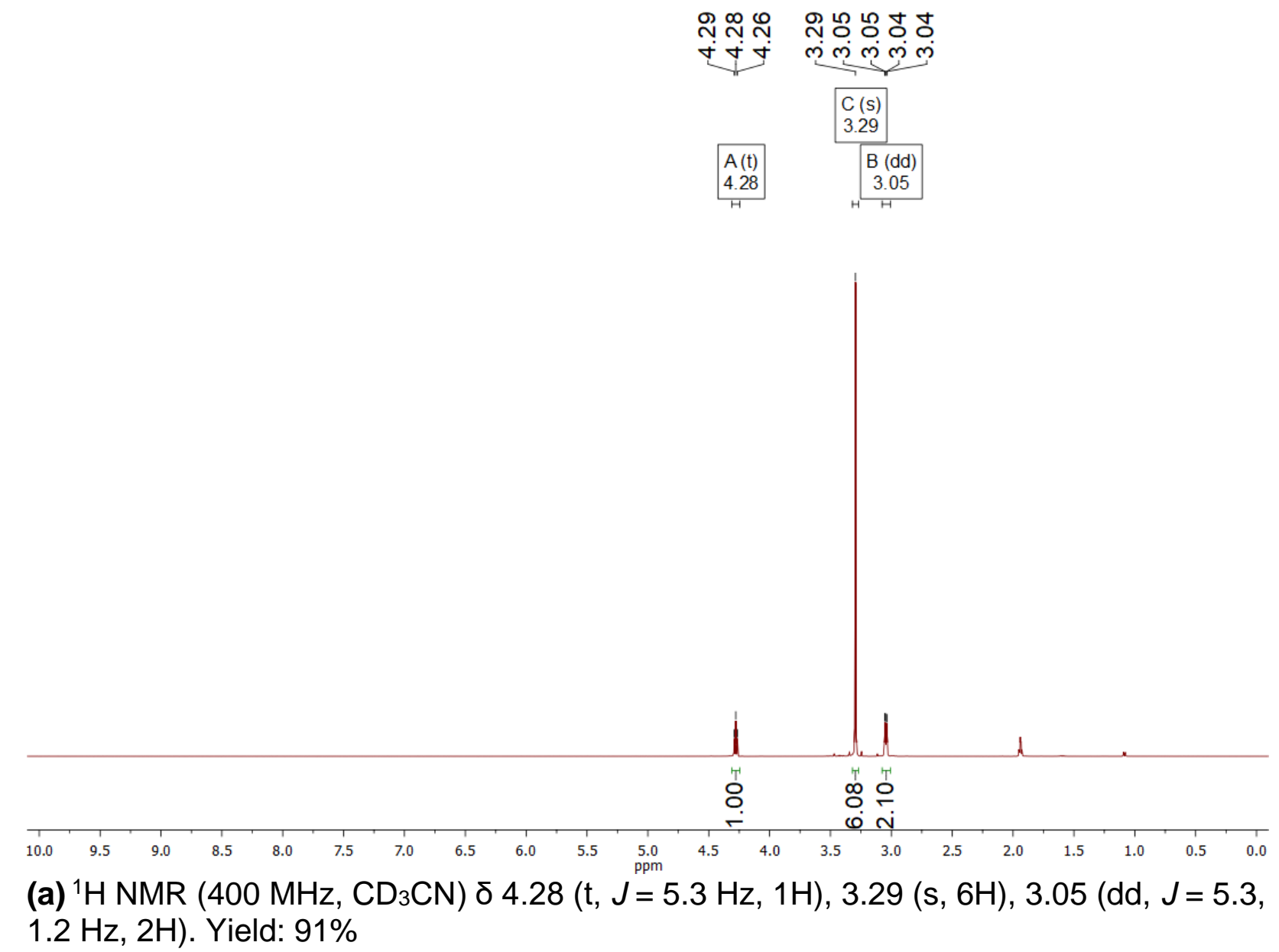




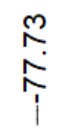

$A(s)$
-77.73

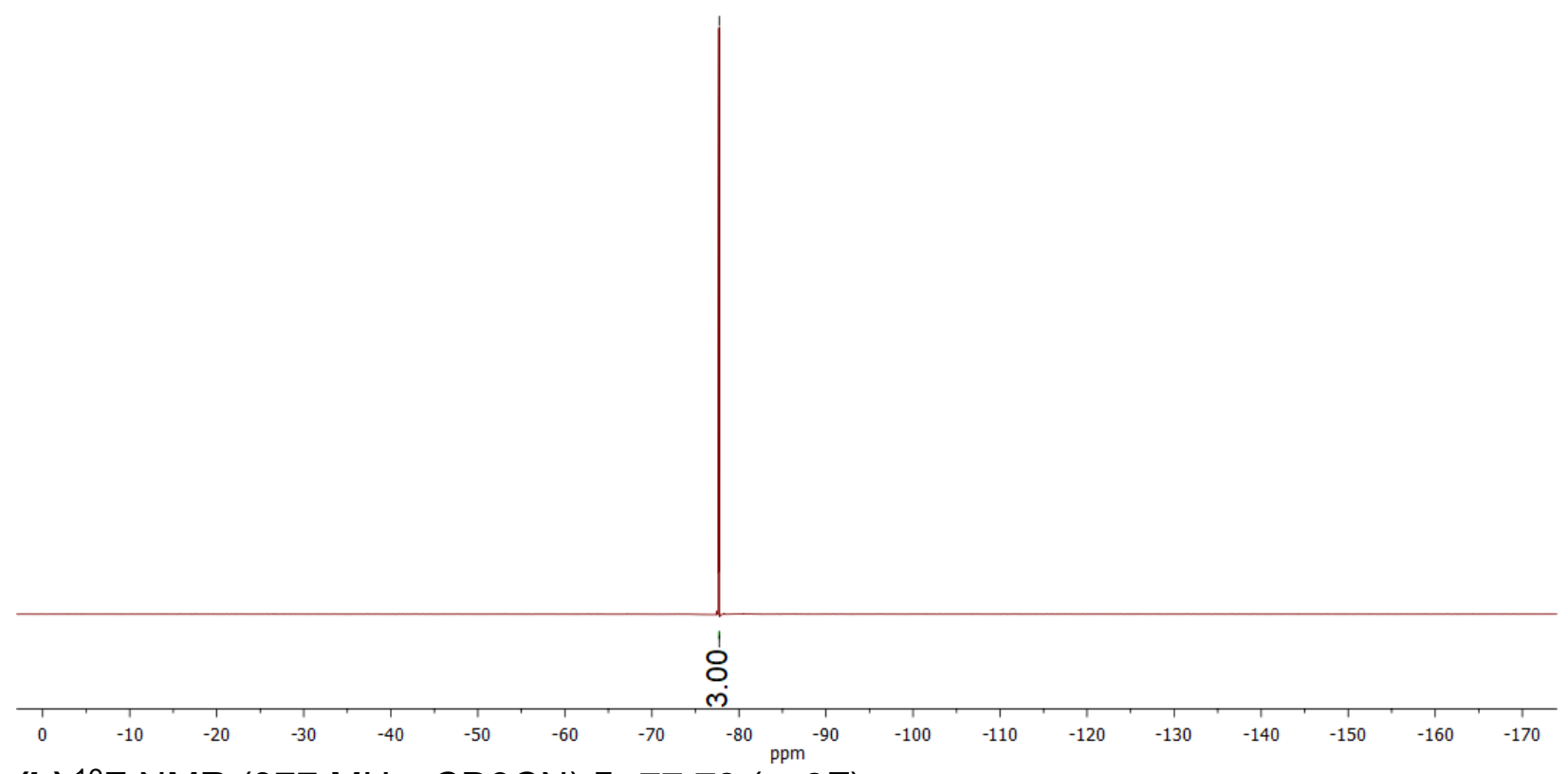

(b) ${ }^{19} \mathrm{~F}$ NMR (377 MHz, CD3CN) $\delta-77.73$ (s, 3F). 
Figure S15. KPMEA

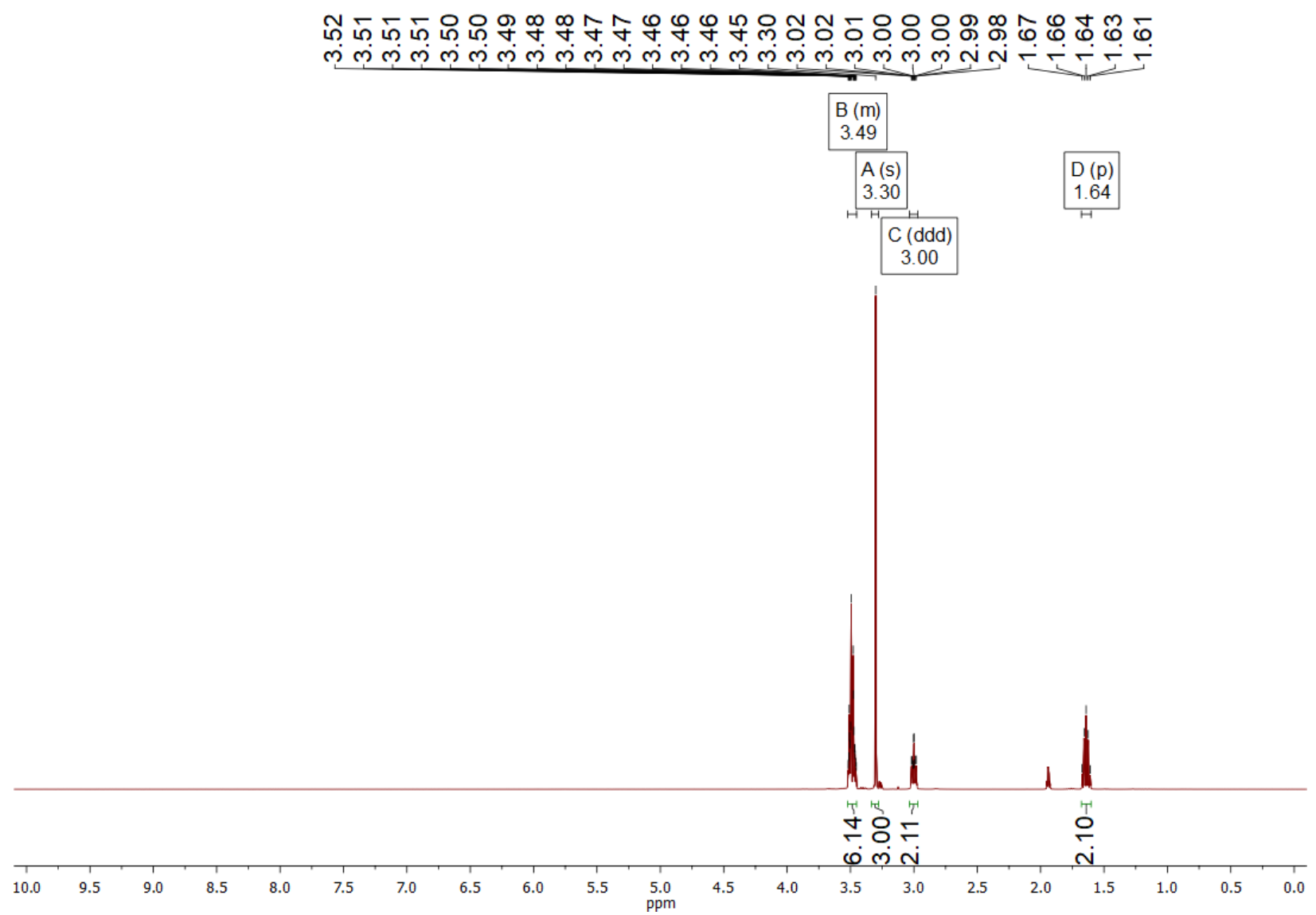

(a) ${ }^{1} \mathrm{H}$ NMR (400 MHz, $\mathrm{CD}_{3} \mathrm{CN}$ ) $\delta 3.52-3.45$ (m, 6H), 3.30 (s, 3H), 3.00 (ddd, J = 7.9, 5.2, $1.4 \mathrm{~Hz}, 2 \mathrm{H}$ ), 1.64 (p, $J=6.3 \mathrm{~Hz}, 2 \mathrm{H}$ ). Yield: $90 \%$ 
N

$A(s)$
-77.46

$-77.46$

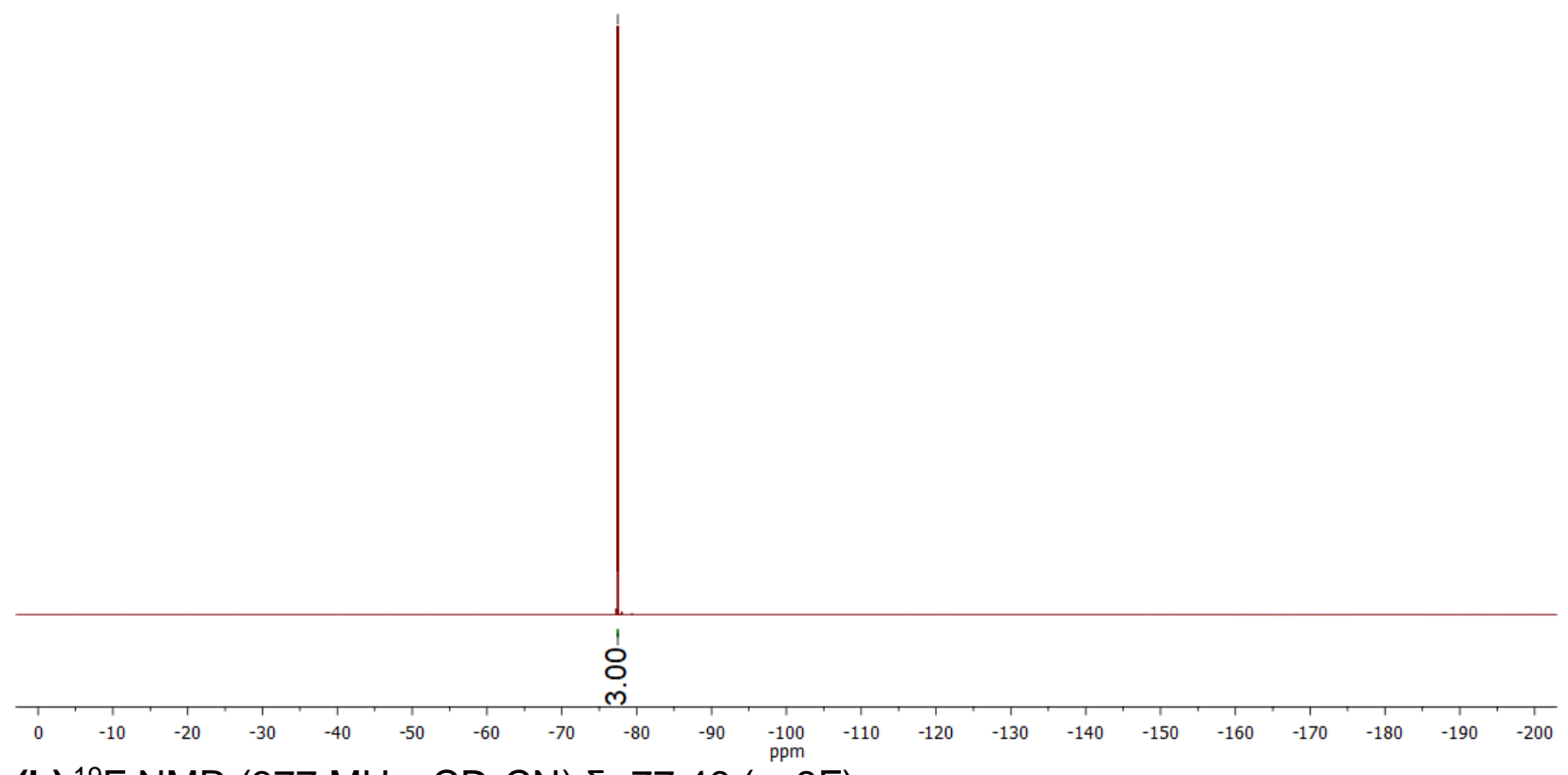

(b) $\left.{ }^{19} \mathrm{~F} \mathrm{NMR} \mathrm{(377} \mathrm{MHz,} \mathrm{CD}_{3} \mathrm{CN}\right) \delta-77.46$ (s, 3F). 
Figure S16. KMTPA

б लंखंल
ભ ભొ

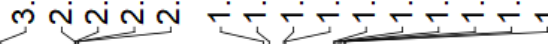

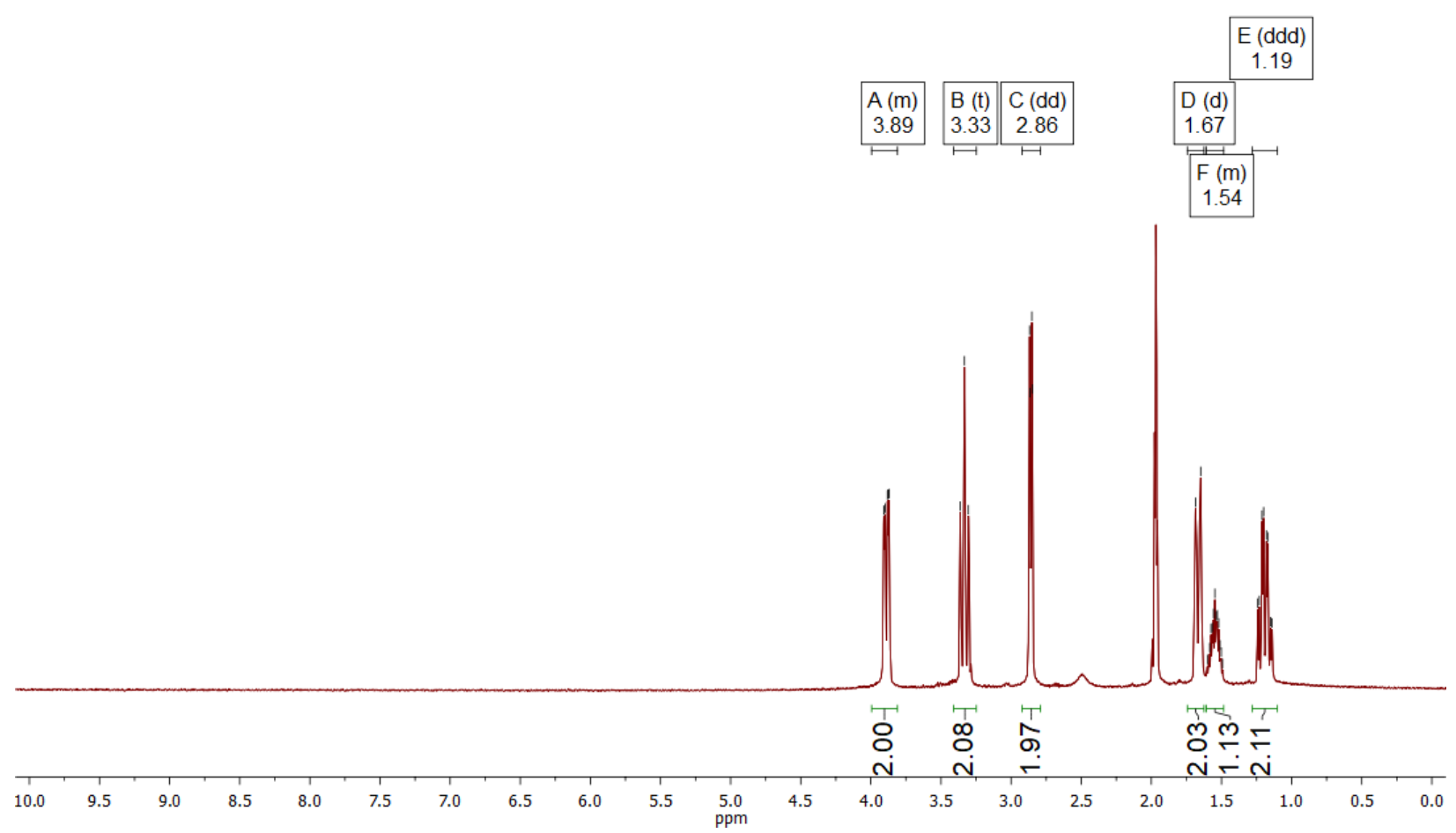

(a) ${ }^{1} \mathrm{H}$ NMR $\left(400 \mathrm{MHz}, \mathrm{CD}_{3} \mathrm{CN}\right) \delta 3.99-3.81(\mathrm{~m}, 2 \mathrm{H}), 3.33(\mathrm{t}, J=11.7 \mathrm{~Hz}, 2 \mathrm{H}), 2.86$ (dd, $J=6.7,1.2 \mathrm{~Hz}, 2 \mathrm{H}), 1.67(\mathrm{~d}, J=14.7 \mathrm{~Hz}, 2 \mathrm{H}), 1.61-1.48(\mathrm{~m}, 1 \mathrm{H}), 1.19$ (ddd, $J=$ 16.4, 12.4, 4.4 Hz, 2H). Yield: $94 \%$ 
กิ

A (s)

$-77.25$

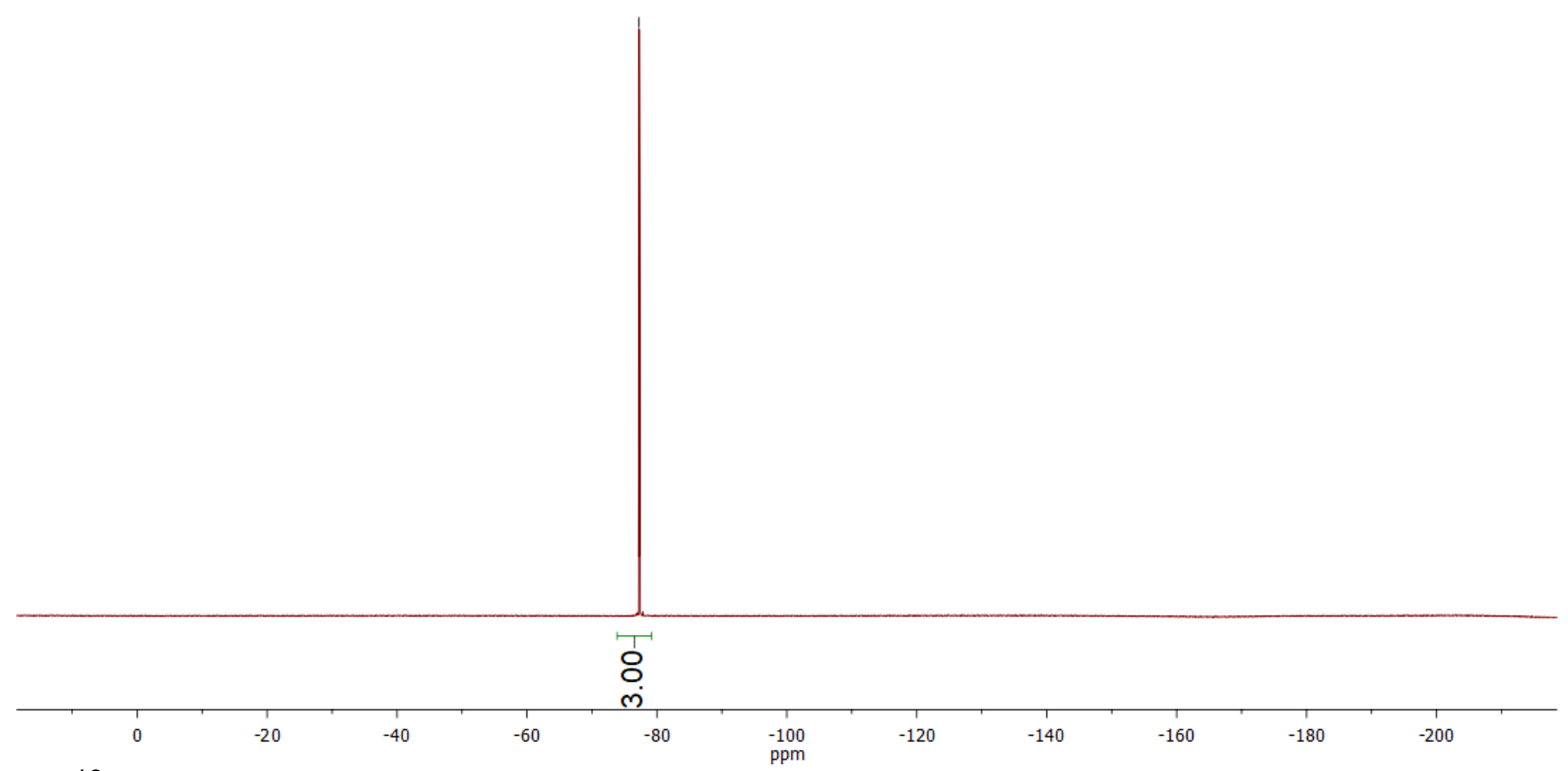

(b) ${ }^{19} \mathrm{~F}$ NMR (377 MHz, CD $\left.{ }_{3} \mathrm{CN}\right) \delta-77.25$ (s, 3F). 
Figure S17. KPTFSA

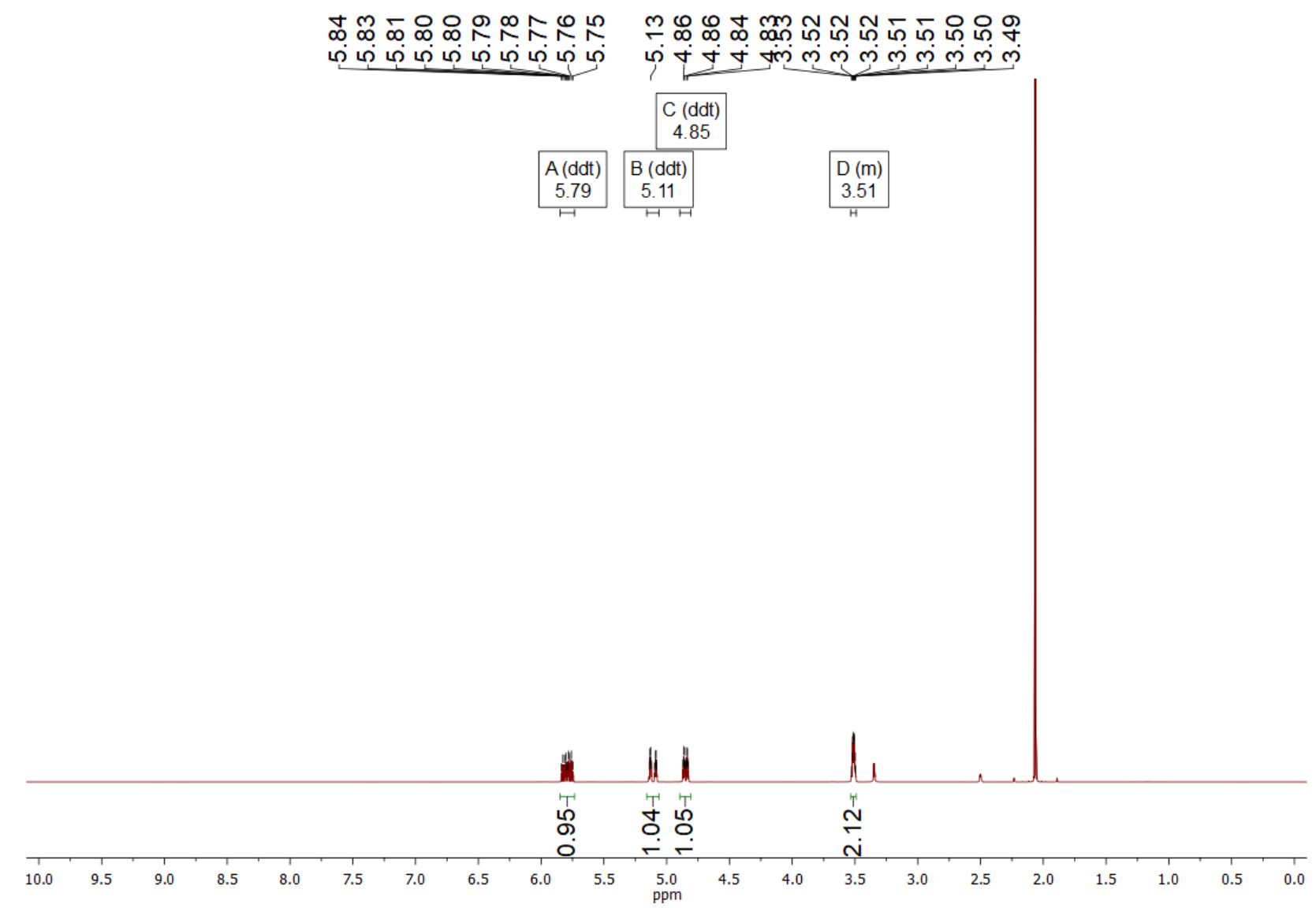

(a) ${ }^{1} \mathrm{H}$ NMR (400 MHz, DMSO) $\delta 5.79$ (ddt, $J=17.0,10.1,5.0 \mathrm{~Hz}, 1 \mathrm{H}$ ), 5.11 (ddt, $J=$ 17.0, 2.6, $2.0 \mathrm{~Hz}, 1 \mathrm{H}$ ), 4.85 (ddt, $J=10.1,2.6,1.8 \mathrm{~Hz}, 1 \mathrm{H}), 3.53-3.49(\mathrm{~m}, 2 \mathrm{H})$. Yield: $95 \%$ 


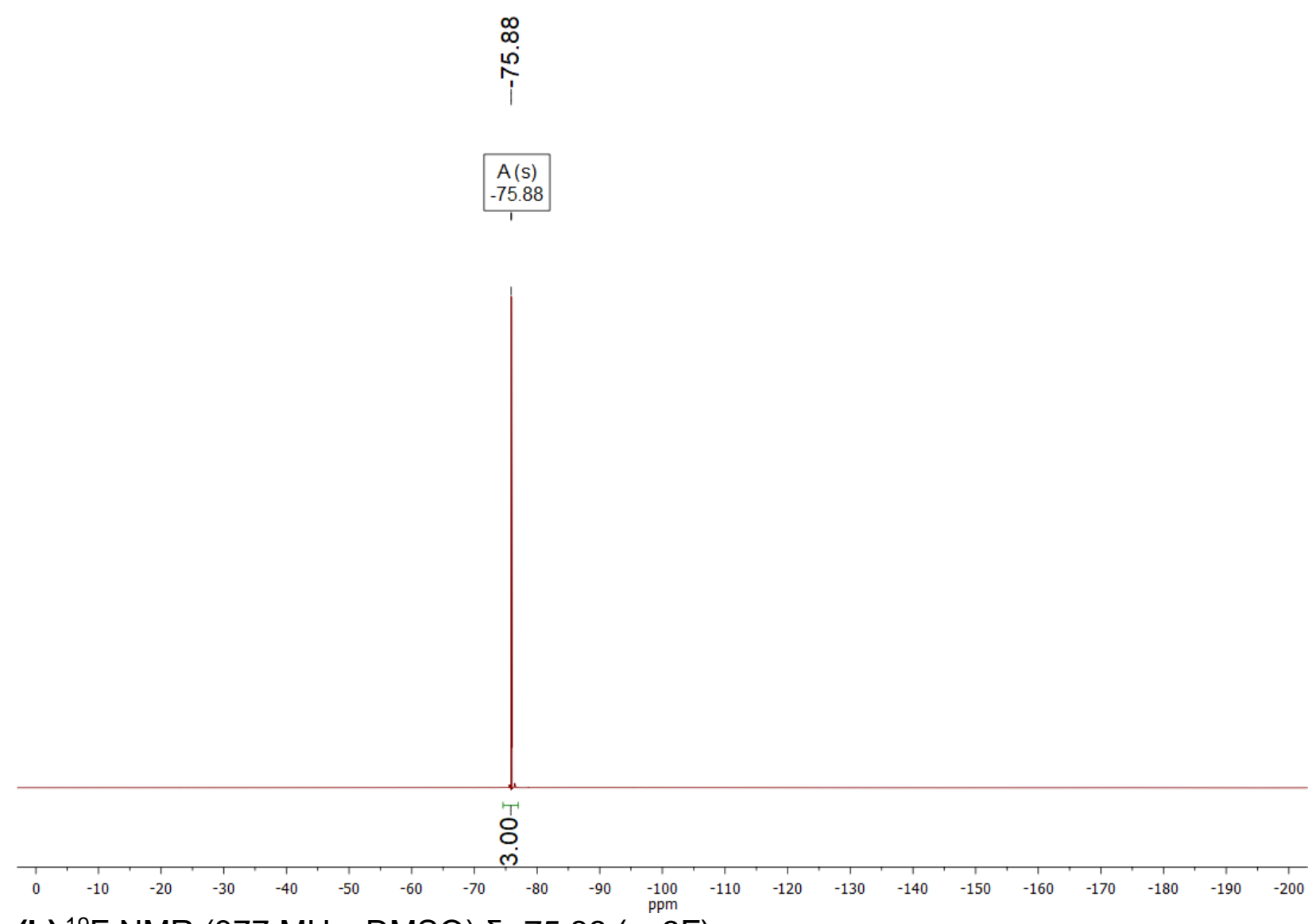

(b) ${ }^{19} \mathrm{~F}$ NMR (377 MHz, DMSO) $\delta-75.88$ (s, 3F). 
Figure S18. KSTFSA

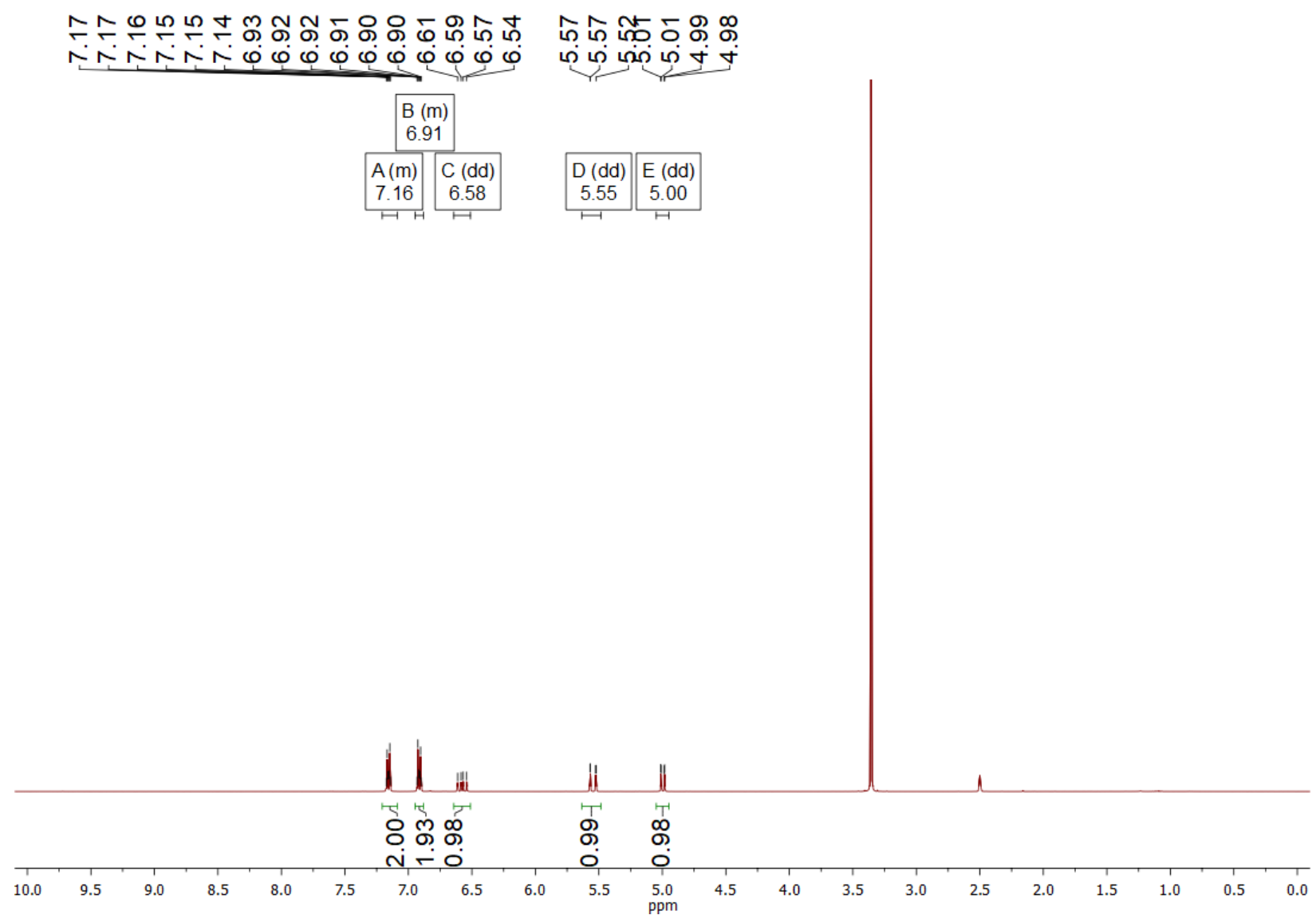

(a) ${ }^{1} \mathrm{H}$ NMR (400 MHz, DMSO) $\delta 7.21-7.09(\mathrm{~m}, 2 \mathrm{H}), 6.95-6.88(\mathrm{~m}, 2 \mathrm{H}), 6.58$ (dd, $J=$ 17.6, $10.9 \mathrm{~Hz}, 1 \mathrm{H}$ ), 5.55 (dd, $J=17.6,1.2 \mathrm{~Hz}, 1 \mathrm{H}), 5.00$ (dd, $J=10.9,1.2 \mathrm{~Hz}, 1 \mathrm{H}$ ).

Yield: $91 \%$ 


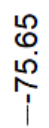

$A(s)$
-75.65

$-75.65$

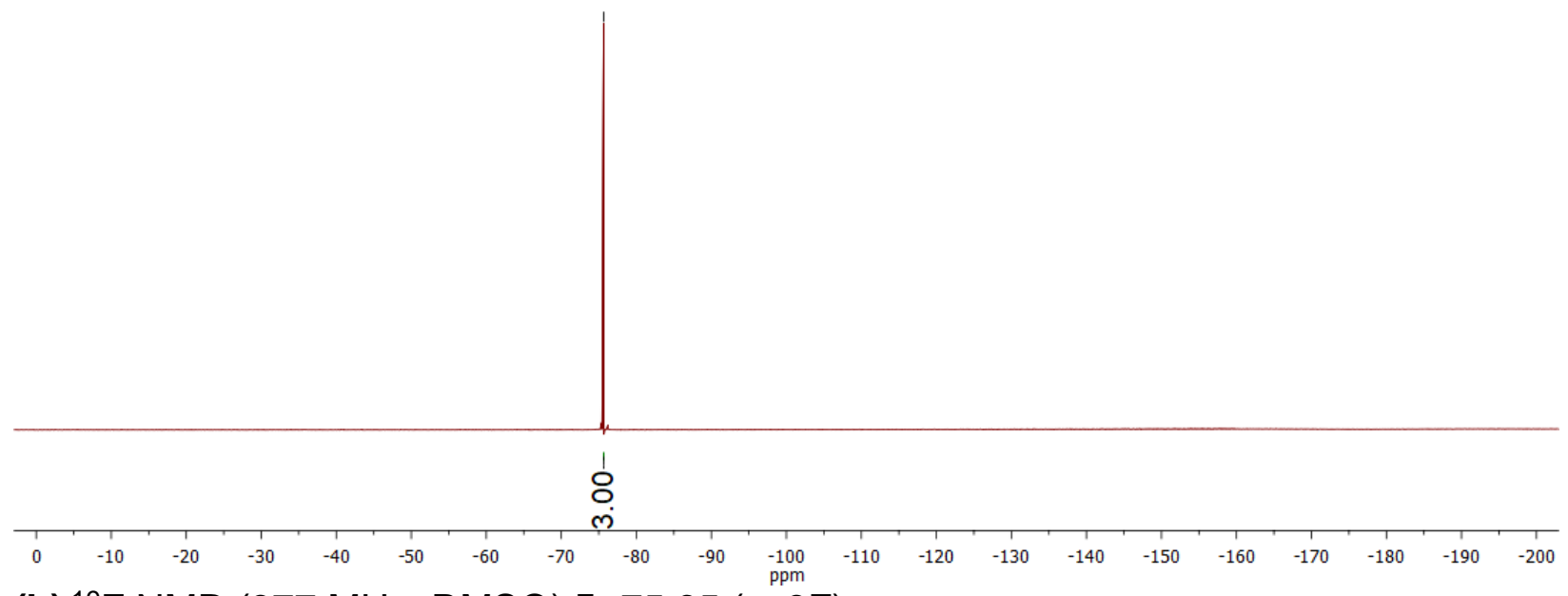

(b) ${ }^{19} \mathrm{~F}$ NMR (377 MHz, DMSO) $\delta-75.65$ (s, 3F). 
Figure S19. KCSTFSA
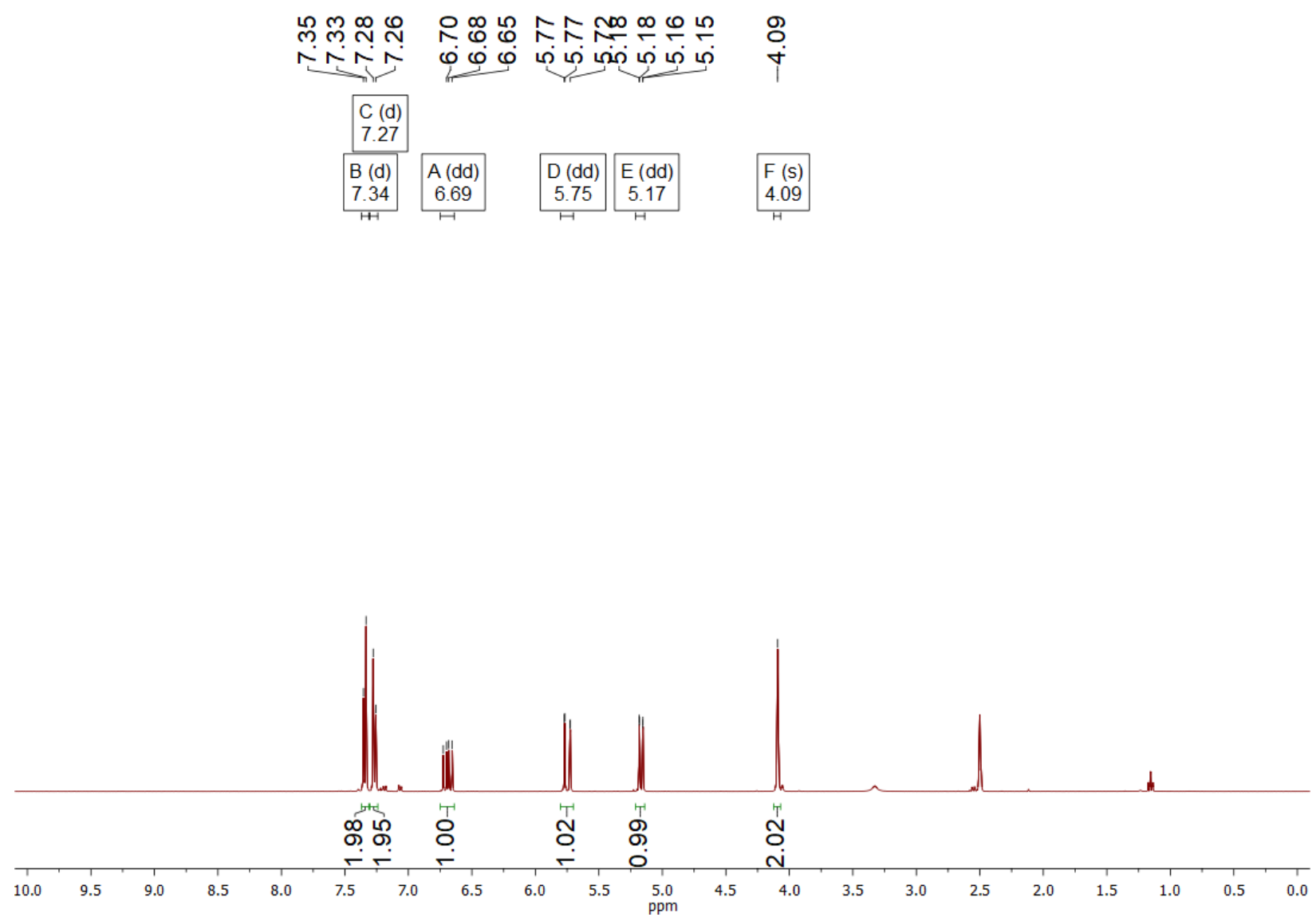

(a) ${ }^{1} \mathrm{H}$ NMR (400 MHz, DMSO) $\delta 7.34(\mathrm{~d}, J=8.1 \mathrm{~Hz}, 2 \mathrm{H}), 7.27(\mathrm{~d}, J=8.2 \mathrm{~Hz}, 2 \mathrm{H}), 6.69$ (dd, $J=17.7,10.9 \mathrm{~Hz}, 1 \mathrm{H}$ ), 5.75 (dd, $J=17.7,1.1 \mathrm{~Hz}, 1 \mathrm{H}$ ), 5.17 (dd, $J=10.9,1.1 \mathrm{~Hz}$, 1H), 4.09 (s, 2H). Yield: 92\% 


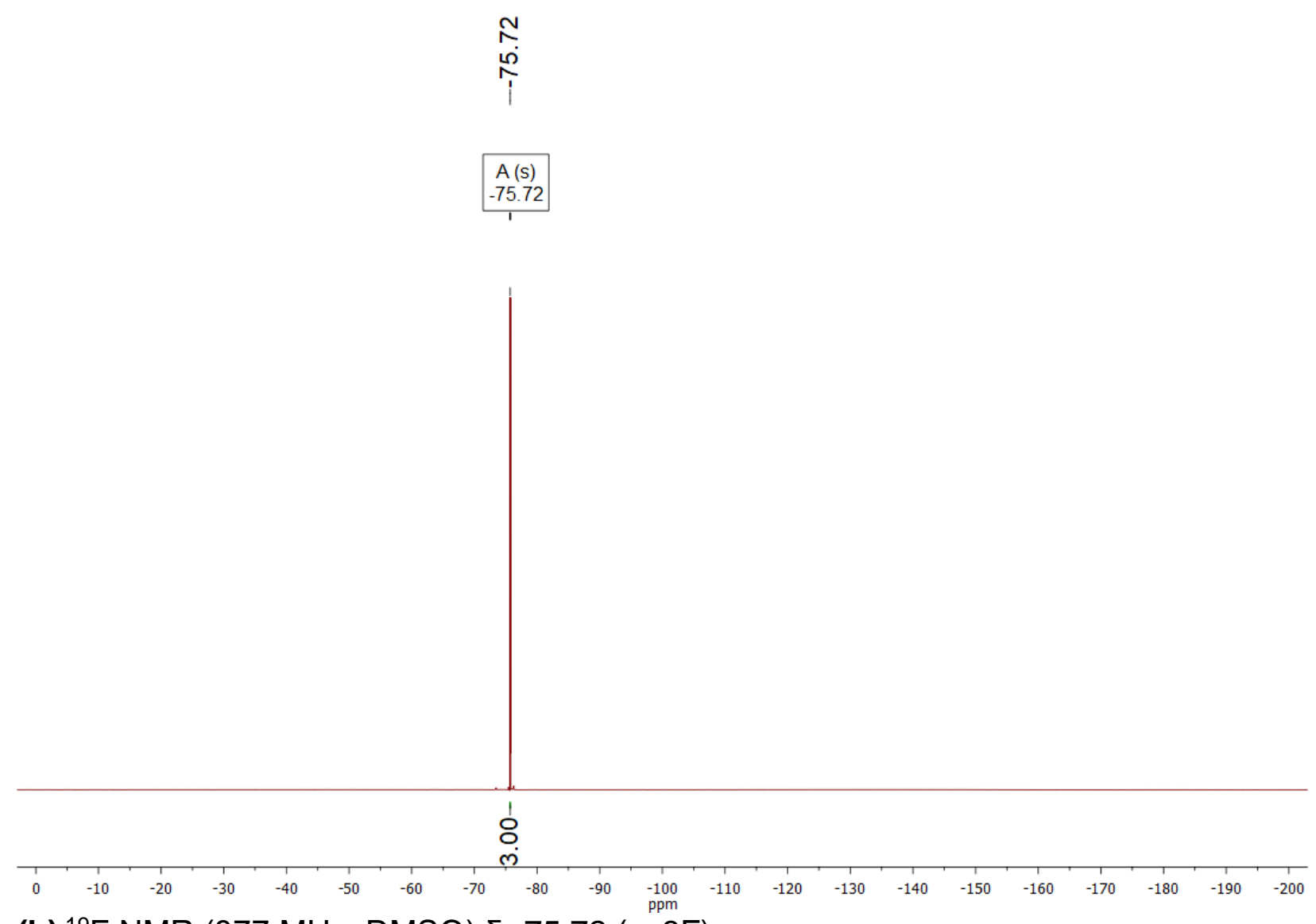

(b) ${ }^{19} \mathrm{~F}$ NMR (377 MHz, DMSO) $\delta-75.72$ (s, 3F). 
Figure S20. KFPSA

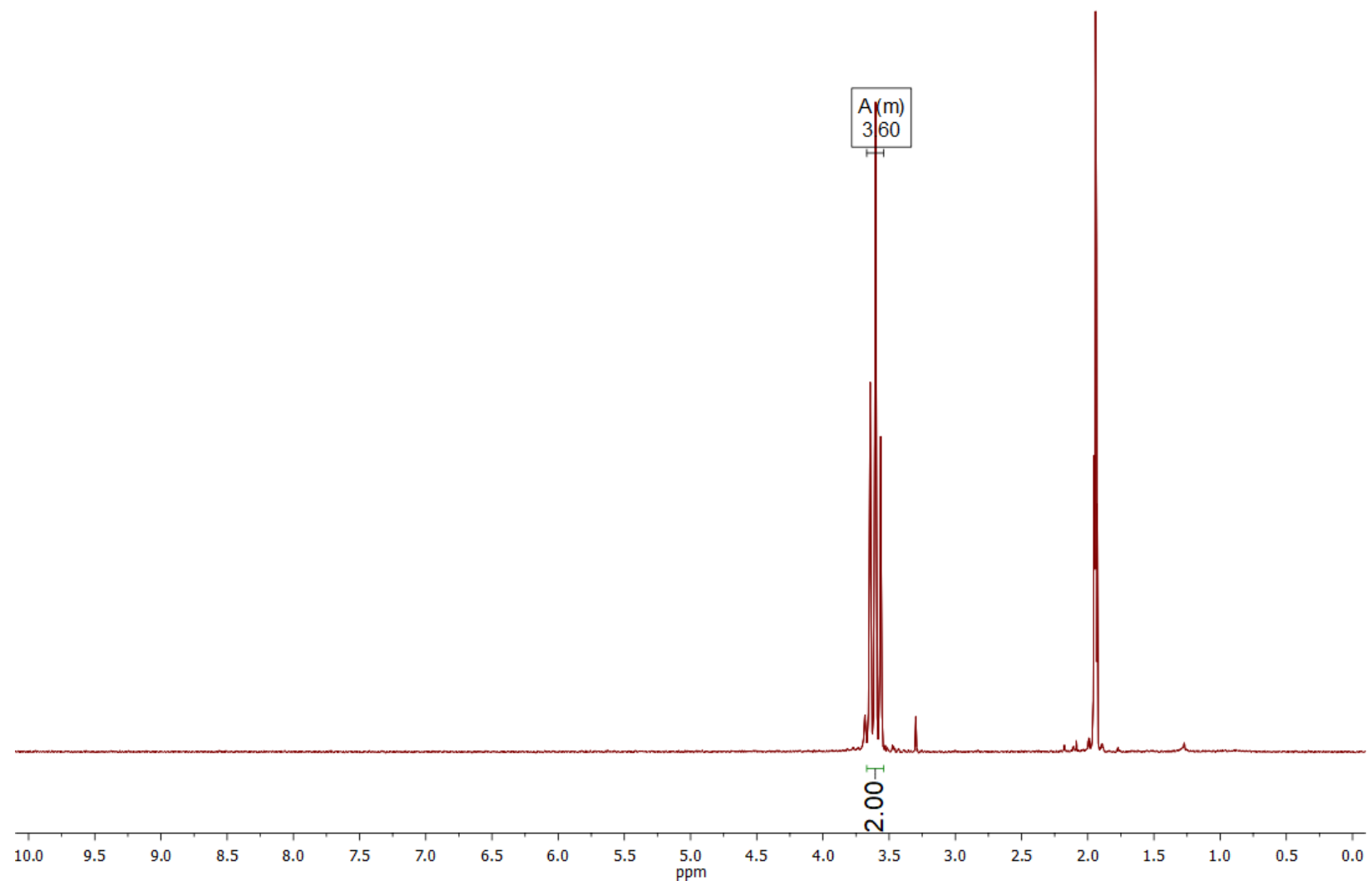

(a) ${ }^{1} \mathrm{H}$ NMR (400 MHz, $\left.\mathrm{CD}_{3} \mathrm{CN}\right) \delta 3.67-3.54(\mathrm{~m}, 2 \mathrm{H})$. Yield: $89 \%$ 

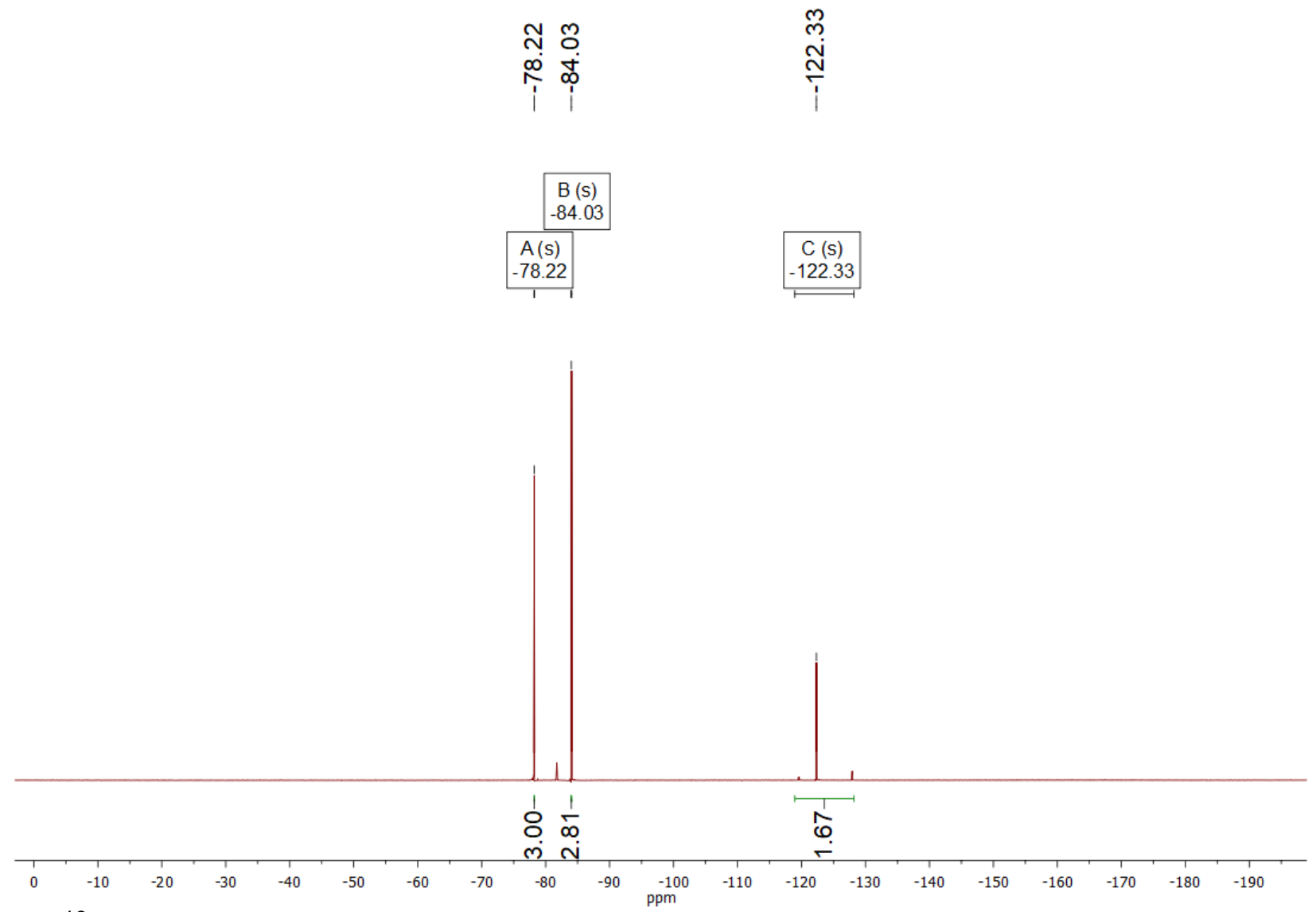

(b) ${ }^{19} \mathrm{~F}$ NMR (377 MHz, CD3CN) $\delta-78.22$ (s, 3F), -84.03 (s, 3F), -122.33 (s, 2F). 
Figure S21. KFBSA

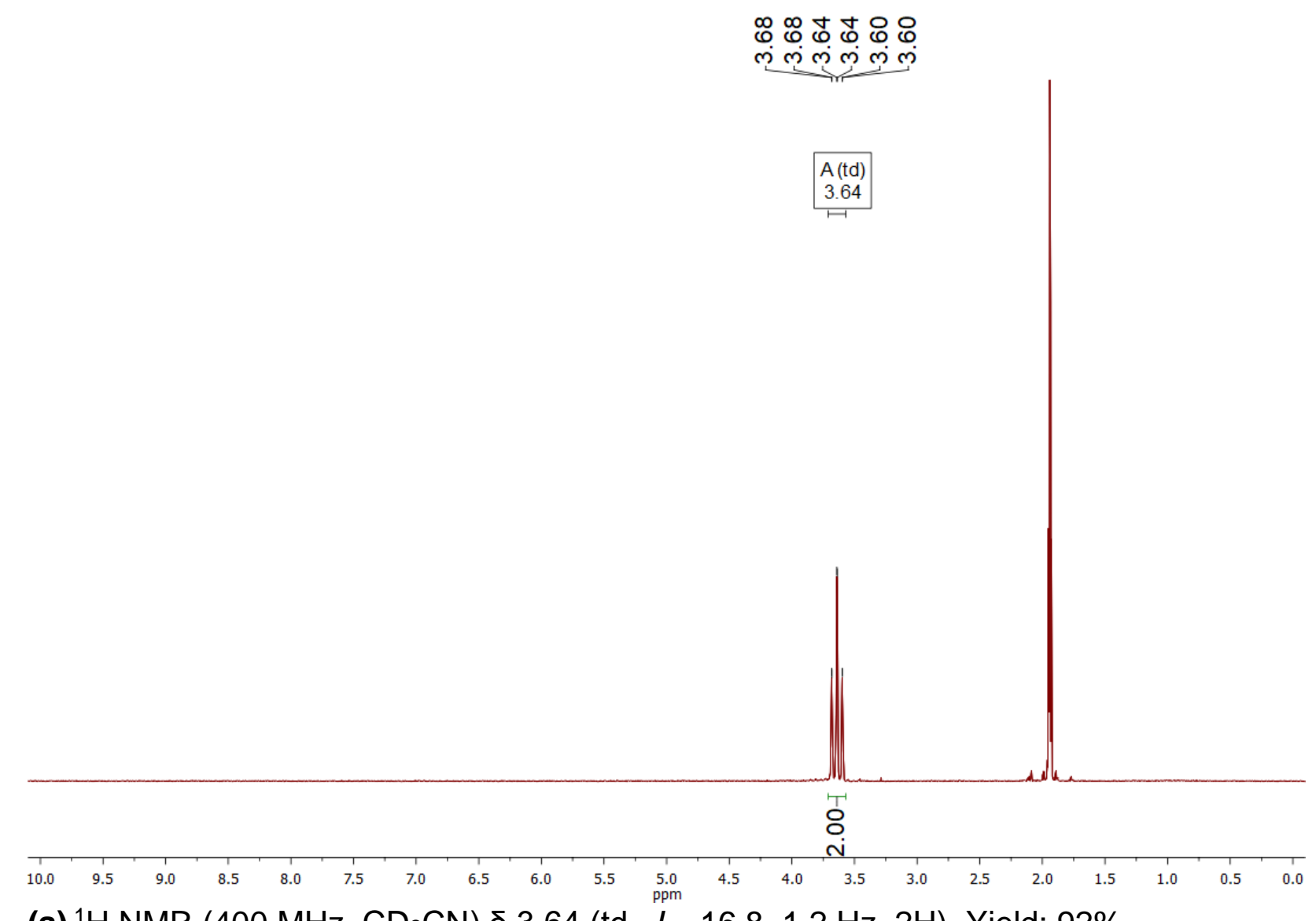

(a) ${ }^{1} \mathrm{H}$ NMR $\left(400 \mathrm{MHz}, \mathrm{CD}_{3} \mathrm{CN}\right) \delta 3.64$ (td, $\left.J=16.8,1.2 \mathrm{~Hz}, 2 \mathrm{H}\right)$. Yield: $92 \%$ 


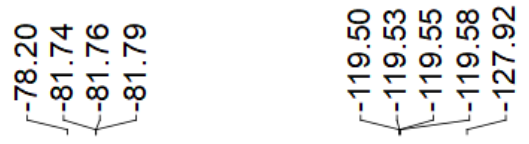

\begin{tabular}{|c|}
\hline $\begin{array}{c}D(s) \\
-78.20\end{array}$ \\
\hline $\begin{array}{c}A(t) \\
-81.76\end{array}$ \\
\hline
\end{tabular}
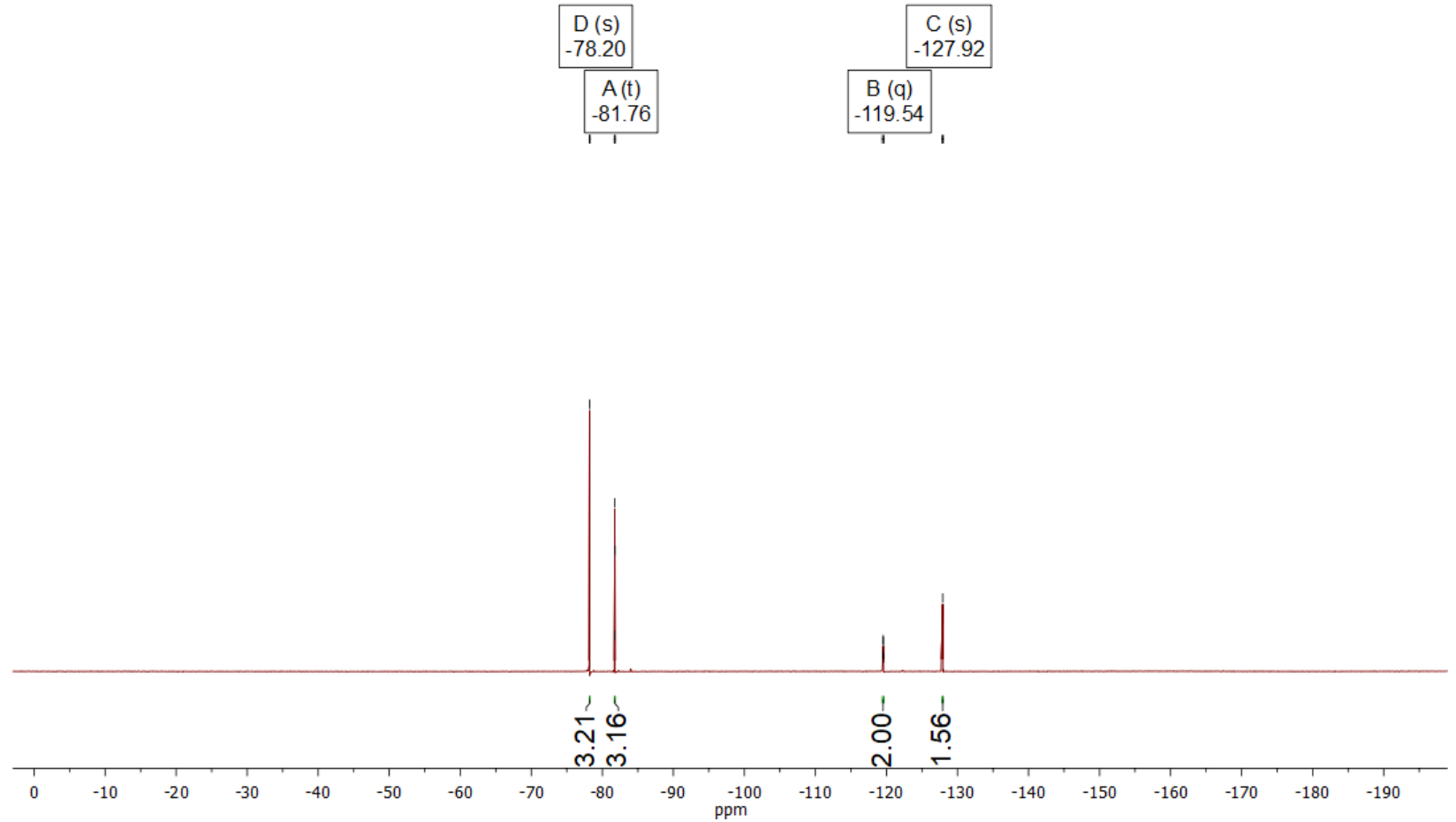

(b) ${ }^{19} \mathrm{~F}$ NMR (377 MHz, CD3CN) $\delta-78.20$ (s, 3F), -81.76 (t, J=9.4Hz, 3F), -119.54 (q, J $=9.6 \mathrm{~Hz}, 2 \mathrm{~F}),-127.92(\mathrm{~s}, 2 \mathrm{~F})$. 
Figure S22. KTMSA
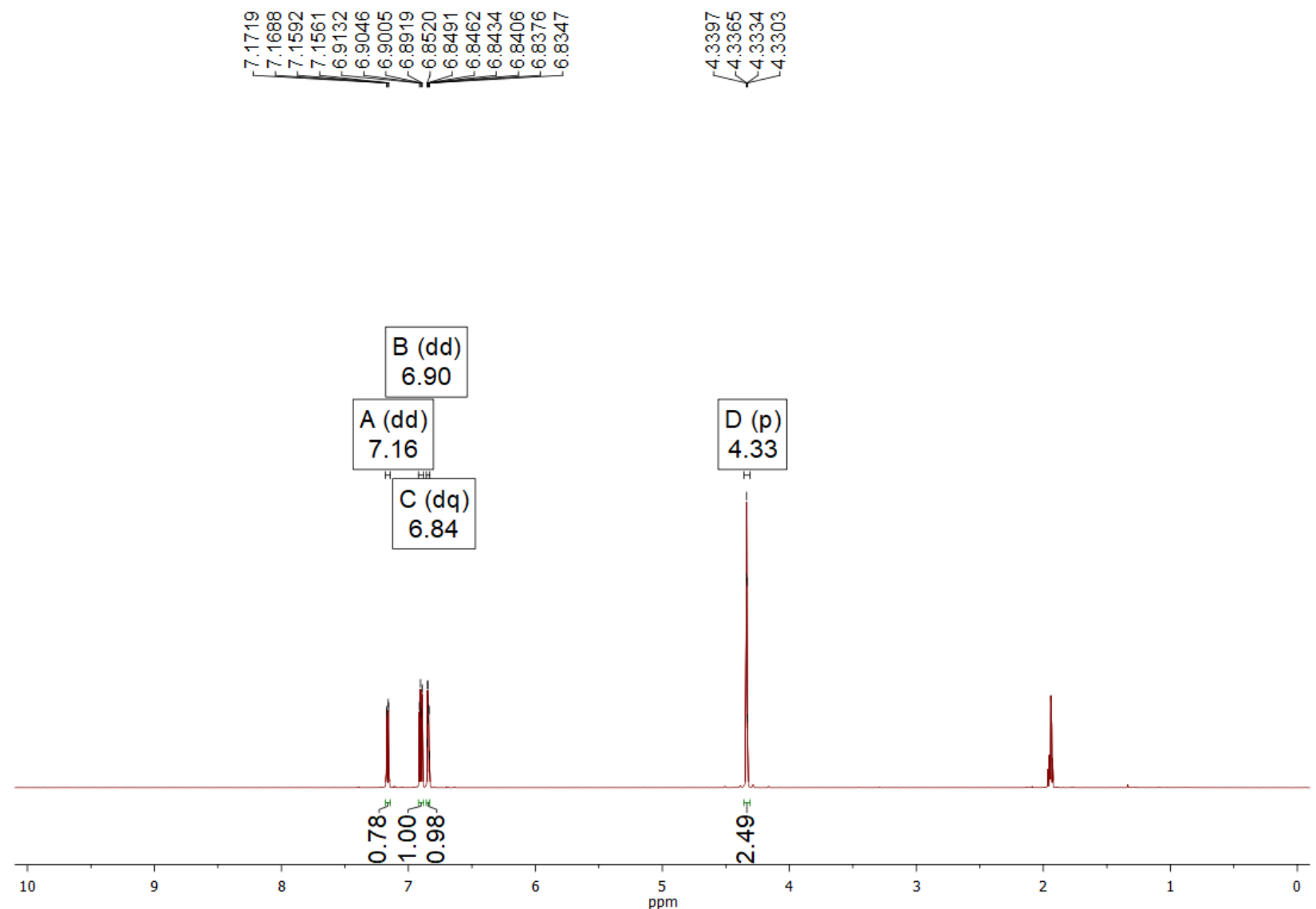

(a) ${ }^{1} \mathrm{H}$ NMR (400 MHz, CD3CN) $\delta 7.16(\mathrm{dd}, \mathrm{J}=5.1,1.2 \mathrm{~Hz}, 1 \mathrm{H}), 6.90(\mathrm{dd}, \mathrm{J}=5.1,3.4$ $\mathrm{Hz}, 1 \mathrm{H}), 6.84(\mathrm{dq}, \mathrm{J}=3.5,1.2 \mathrm{~Hz}, 1 \mathrm{H}), 4.33(\mathrm{p}, \mathrm{J}=1.2 \mathrm{~Hz}, 2 \mathrm{H})$. Yield: $87 \%$ 


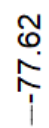

\begin{tabular}{|c|}
\hline A (s) \\
-77.62 \\
\hline
\end{tabular}

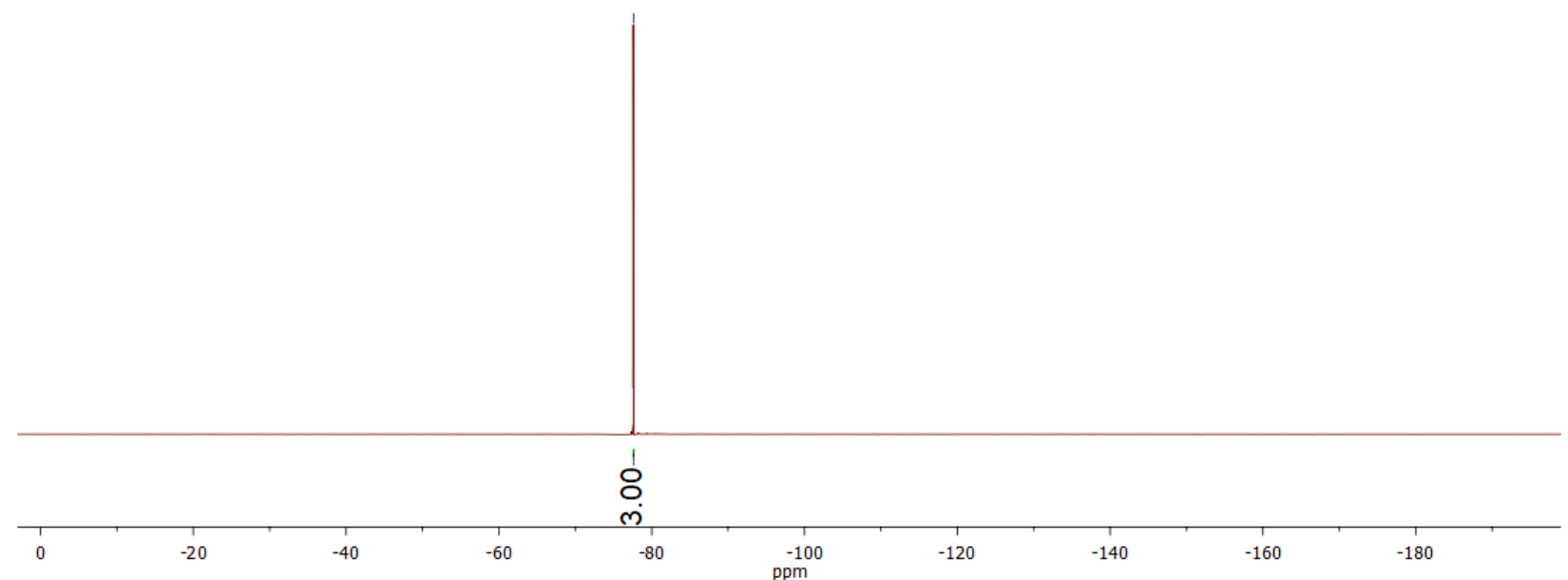

(b) ${ }^{19} \mathrm{~F}$ NMR (377 MHz, CD3CN) $\delta-77.62(\mathrm{~s}, 3 \mathrm{~F})$. 


\section{Supplementary Crystal Structure Analysis:}

Structure of KPMEA: The salt features a single unique $\mathrm{K}$ and PMEA site. The $\mathrm{K}$ cation has distorted octahedral coordination to three sulfonyl $\mathrm{O}$, two ether $\mathrm{O}$, and one $\mathrm{N}$. These coordinating atoms come from four separate anions. Two of these sulfonyl $\mathrm{O} 3$ participate to form planar K-O dimers (Figure S23a). These same sulfonyl O3 coordinate in a bidentate fashion to one of the $\mathrm{K}$ ions with the $\mathrm{N}$ of their own anion. A larger bridging interaction involving the third sulfonyl $\mathrm{O}$ and the two ether $\mathrm{O}$ also connects the nearest neighbor $\mathrm{K}$ sites. The sulfonyl $\mathrm{O}$ coordinates the first $\mathrm{K}$ while the two ether $\mathrm{O}$ chelate the other K. On a slightly larger scale, these K-O dimers are connected to each in infinite 1$\mathrm{D}$ chains. Specifically, each $\mathrm{K}-\mathrm{O}$ dimer is connected to another dimer through sulfonyl O4 (Figure S26).

The packing of the KPMEA follows the aforementioned chains (Figure S25a). Unlike the 2-D layers and 1-D tunnels form in the symmetric alkali metal TFSI series, there are 1-D chains of $\mathrm{K}-\mathrm{O}$ dimers along the a-axis segregated by the $\mathrm{CF}_{3}$ and ether side chains. These chains form roughly rectangular domains with an ionic center and hydrophobic exterior.

The coordination of the anion includes four separate $\mathrm{K}$ cations (Figure S24a). Every $\mathrm{O}$ and $\mathrm{N}$ from the anion is coordinated to at least one $\mathrm{K}$. Both ethers coordinate to the same K. Sulfonyl $\mathrm{O} 3$ directly bridges $2 \mathrm{~K}$, while the other sulfonyl $\mathrm{O} 4$ bonds to just 1 $\mathrm{K}$. The bridging $\mathrm{O} 3$ and the $\mathrm{N} 1$ coordinate in a bidentate fashion to the same $\mathrm{K}$ cation.

Structure of KDESA: The salt features a single unique site for both $\mathrm{K}$ and DESA. Despite this, the coordination environment of the $\mathrm{K}$ cation is complex, binding to a variety of a different atoms from DESA. Each $\mathrm{K}$ is seven-coordinate, including two sulfonyl $\mathrm{O}$, two ether $\mathrm{O}$, two $\mathrm{N}$ and one $\mathrm{F}$ (Figure $\mathrm{S} 23 \mathrm{~b}$ ). The coordinating atoms derive from four different DESA anions. Each nearest neighbor $\mathrm{K}$ pair forms a planar $\mathrm{K}-\mathrm{N}$ dimer from two $\mathrm{K}$ and two $\mathrm{N}$. The K-N dimers connect to each other through the sulfonyl moiety along the a-axis and the ether side chains along the b-axis. These structures propagate in 2dimensions within each layer (Figure S27). The $\mathrm{N}$ from the $\mathrm{K}-\mathrm{N}$ dimer together with a sulfonyl $\mathrm{O} 4$ coordinate in a bidentate fashion to $\mathrm{K}$. There is an additional tridentate chelation between one ether $\mathrm{O}$, one $\mathrm{N}$ and one $\mathrm{F}$. This tridentate interaction forms two puckered five-member rings which share the $\mathrm{K}-\mathrm{N}$ bond. These rings resemble each other greatly, despite the different atoms involved in the respective rings. Despite the resemblance, the K-F ring is much larger due to overall larger bond lengths including $\mathrm{K} 1$ F2 (2.9960(9) $\AA$ ) and N1-S1 (1.5265(11) A) compared to the respective bonds of the K-O ring, K1-O4 (2.7203(10) $\AA$ ), and N1-C1 (1.4691(17) $\AA$ ). The final DESA anion coordinates by a single ether $\mathrm{O}$ to the $\mathrm{K}$.

The overall packing is quite similar to that of the symmetric KTFSI analogue, and results in a segregation layer which includes all of the available triflouromethyls (Figure $25 \mathrm{~b}$ ). These layers may be thought of as consisting of ionic core layer surrounded by a hydrophobic interlayer. Unlike in the KTFSI crystal structure, there is substantial aliphatic carbon character in the segregation layer. Both methoxy carbons (C3 and C4) contribute to stabilizing the interlayer.

The coordination structure of DESA is quite complex (Figure S24b). Each anion coordinates four $\mathrm{K}$. This includes monodentate coordination from sulfonyl $\mathrm{O} 3$ and ether 
O1. There is a bidentate interaction involving sulfonyl $\mathrm{O} 4$ and N1. There is also a tridentate coordination structure involving F2, N1, and ether O2. Unusual for this series of salts, the only bridging atom is $\mathrm{N} 1$, neither sulfonyl $\mathrm{O}$ coordinates to multiple $\mathrm{K}$.

Structure of KMTPA: There are three unique K (K1, K1' and K1") and two unique MTPA (MTPA1 and MTPA1') sites found throughout the crystal structure. However, the K1' and K1" sites are only half occupied, leaving systematic absences throughout the crystal structure, as well as balancing the charge of the salt. All three $\mathrm{K}$ sites have coordination numbers of only six, leaving them relatively unsaturated. $\mathrm{K} 1$ coordinates with three $\mathrm{N}$ and three sulfonyl $\mathrm{O}$, forming a $\mathrm{K}-\mathrm{N}$ dimer between the nearest neighbor $\mathrm{K} 1$ sites (Figure S23c). This structure is analogous to the K-N dimer found within the KDESA crystal structure. A key difference, however, is that this $\mathrm{K}-\mathrm{N}$ dimer is not planar and has a dihedral angle of $30.99(11)^{\circ}\left(\Omega K 1-N 1^{\prime}-\mathrm{K} 1-\mathrm{N} 1{ }^{\prime}\right)$. In addition, each $\mathrm{K} 1$ forms a K-O dimer with a single K1' cation (Figure S28). The coordination structures of K1' and K1" are very similar, involving four sulfonyl $\mathrm{O}$ and two ether $\mathrm{O}$ to each site, with slightly distorted octahedral geometry (Figure S23d). Interestingly, all of the coordinations to K1' and K1" are monodentate. The only difference between these two $\mathrm{K}^{+}$sites is the length of their various $\mathrm{K}-\mathrm{O}$ bonds. $\mathrm{K} 1$ '-ether $\mathrm{O} 1$ (both 2.654(3) $\AA$ ) is shorter than $\mathrm{K} 1$ '"-ether O1' (2.692(3) $\AA$ ). The coordination length to the sulfonyl $\mathrm{O}$ is more complicated. The $\mathrm{K}$-sulfonyl $\mathrm{O}$ bond length trans to the ether $\mathrm{O}$ ligand are shorter in the case of K1'-O2' than $\mathrm{K} 1$ '"-O2 (2.718(3) $\AA$ vs $2.737(3) \AA$ ). The $\mathrm{K}$-sulfonyl $\mathrm{O}$ coordination trans to another sulfonyl $\mathrm{O}$ is longer for K1'-O3 than K1"'-O3' (2.740(3) A vs 2.624(3) Å). K1' and K1" form a puckered eightmember ring through two sulfonyl moieties from MTPA1 and MTPA1'. This ring is "capped" by a O2-K1-O2' three atom chain (Figure S28). O2 coordinates to K1", while O2' coordinates to K1', with a K1 site in between the aforementioned sulfonyl oxygens forming the "cap".

The packing of the KMTPA forms segregated 1D tunnels (Figure 25c). These tunnels are formed by the same fluorine segregation as the layers found in KDESA, and like those layers require the hydrophobic interaction of the aliphatic $C$ within the ether side chain in order to remain stable. In this case the C5, C6, C5', and C6' sites participate in the segregation stabilization. In additional there exists a single DCM site for every two salts compounds, which sits within the segregated tunnel. Each DCM is surrounded by 4 trifluoromethyls and 8 ether side chains. However, the refinement of this site reveals a chemical occupancy of 0.5 , suggesting that not every DCM site holds a molecule. Therefore, the ratio between KMPTA and DCM is held at 0.25 . Interestingly the DCM molecule sits on an inversion center within the unit cell, resulting in two possible positions at each DCM site. In between the segregated tunnels lies the "ionic region" with 1-D chains of $\mathrm{K}$ clusters. The ether side chain serves to connect the various ionic regions together while also forming the exterior of the hydrophobic tunnels. The ionic region lies to the "cardinal directions" of the tunnels, while the aliphatic carbons are positioned diagonally to the tunnels, in the orientation of Figure $5 \mathrm{c}$.

The coordination of the two anion sites are surprisingly similar considering the vast differences between the $\mathrm{K} 1$ and the other two $\mathrm{K}$ sites. The MTPA1 site coordinates to five $\mathrm{K}$ cations (Figure $\mathrm{S} 24 \mathrm{c}$ ). The ether $\mathrm{O} 1$ coordinates a single $\mathrm{K} 1$ '. In contrast, both sulfonyl $\mathrm{O} 2$ and $\mathrm{O} 3$ bridge two $\mathrm{K}$. In addition, $\mathrm{O} 2$, together with $\mathrm{N} 1$ forms a bidentate interaction to K1. The MTPA1' site also coordinates five K cations (Figure S24d). Both ether O1' and 
sulfonyl O3' both coordinate a single K1" cation. Sulfonyl O2' bridges two K sites, one of which (K1) is shared with N1'. Interestingly N1' also bridges two K sites, both K1.

Structure of KMPSA: The crystal structure of KMPSA features three unique K (K1, K1' and K1") and MPSA (MPSA1, MPSA1', MPSA1") sites. The coordination of the K cations includes interactions from many different atoms on multiple MPSA anions. K1 is coordinated by eight atoms from four different anions (Figure S23e). These includes four sulfonyl $\mathrm{O}$, one $\mathrm{N}$, one ether $\mathrm{O}$, and two $\mathrm{F}$. Of the four sulfonyl $\mathrm{O}$, two are shared with the nearest $\mathrm{K} 1$ neighbor forming a planar $\mathrm{K}-\mathrm{O}$ dimer. The two MPSA anions involved with the $\mathrm{K} 1-\mathrm{O}$ dimer bind in a tridentate fashion to one $\mathrm{K} 1$ (through two sulfonyl $\mathrm{O}$ and one $\mathrm{F}$ ) and form a puckered eight-member ring with the other $\mathrm{K} 1$ cation. This large ring involves the ether $\mathrm{O}$ of the referenced MPSA as well as the bridging sulfonyl O. Another MPSA coordinates to $\mathrm{K} 1$ through one of its sulfonyl $\mathrm{O}$ and its $\mathrm{N}$ forming a bidentate interaction. The fourth MPSA coordinates to K1 through F on the trifluoromethyl moiety.

$\mathrm{K} 1^{\prime}$ is also eight-coordinate, through six sulfonyl $\mathrm{O}$ and two $\mathrm{N}$, from five different MPSA anions (Figure S23f). Similar to K1, K1' forms planar K-O dimers through bridging sulfonyl $\mathrm{O}$. However, $\mathrm{K} 1$ ' forms two dimer structures through 4 separate sulfonyl $\mathrm{O}$. These dimers are orthogonal to each other. All 4 MPSA anions involved in these dimers coordinate in a bidentate fashion to $\mathrm{K} 1$ ' through the bridging sulfonyl $\mathrm{O}$ and the $\mathrm{N}$ of the MPSA. Finally, the fifth MPSA anion coordinates in a bidentate fashion through its two sulfonyl $\mathrm{O}$ to $\mathrm{K} 1$ '.

$\mathrm{K} 1$ " is seven-coordinate, involving four sulfonyl $\mathrm{O}$, two $\mathrm{N}$, two ether $\mathrm{O}$, and one $\mathrm{F}$ (Figure S23g). These atoms derive from five separate MPSA anions. Just like K1 and K1', $\mathrm{K} 1$ " forms planar $\mathrm{K}-\mathrm{O}$ dimers, in this case, only a single dimer with two sulfonyl $\mathrm{O}$. In addition, similar to $\mathrm{K} 1$, the ether $\mathrm{O}$ of the bridging MPSA anion forms a puckered eightmember ring through the bridging sulfonyl $\mathrm{O}$, the anion's ether $\mathrm{O}$ and $\mathrm{K} 1$ ". However, the coordination of K1" also features a more unusual bridging interaction. Two MPSA1 anions and two K1" form an elongated 10-member ring. The coordination between MPSA1 and $\mathrm{K} 1$ " is through the $\mathrm{N} 1$ and $\mathrm{F} 2$. In addition, the $\mathrm{K} 1-\mathrm{F} 3$ bond is relatively short, only $2.8825(9) \AA$, on the same order of length as the K-N bond involved in the 10-member ring, $2.8830(12) \AA$. The $5^{\text {th }}$ MPSA anion coordinates to K1" through 1 sulfonyl O.

Examining the environment between these unique $\mathrm{K}$ sites reveals more interesting coordination structures (Figure S29). The six nearest neighbor K1, K1' and K1" cations (two of each) share a complex bridging coordination sphere. The $\mathrm{K} 1$ ' "double dimer" sits in between two K1 and two K1" positions, with one of each K site sitting on either side of the double dimer. Seven of the eight coordinating atoms to K1' also coordinates to a different $\mathrm{K}$ site. This includes the 4 sulfonyl $\mathrm{O}$ involved in the $\mathrm{K} 1$ ' double dimers. This results in the formation of K-O dimers separately between $\mathrm{K} 1$ ' and $\mathrm{K} 1$ as well as $\mathrm{K} 1$ ' and $\mathrm{K} 1$ ". However, while the $\mathrm{K}-\mathrm{O}$ dimers between 2 symmetrically equivalent $\mathrm{K}$ are all planar, the K-O dimers between different $\mathrm{K}$ sites feature dihedral angles of $149.90(4)^{\circ}(\Omega \mathrm{K} 1-\mathrm{O} 3-$ $\mathrm{K} 1^{\prime}-\mathrm{O} 3$ ") and $128.73(4)^{\circ}\left(\Omega \mathrm{K} 1^{\prime}-\mathrm{O} 22^{\prime \prime}-\mathrm{K} 1{ }^{\prime \prime}-\mathrm{O} 22^{\prime \prime}\right)$. Two analogous structures involving K1', $\mathrm{K} 1$ ", one sulfonyl $\mathrm{O}$ and one $\mathrm{N}$ in a four-member ring are also observed. Both of these structures share the $\mathrm{N} 1$ site, however the sulfonyl oxygen varies. Both $\mathrm{O} 2$ ' and $\mathrm{O} 2$ " form a K1'-N1 -K1"- O2('and") four-member ring [ $\Omega \mathrm{K} 1$ '-N1-K1"-O2' = 43.42(3) ${ }^{\circ}, \Omega \mathrm{K} 1$ '-N1-K1"$\left.\mathrm{O} 2 "=42.76(4)^{\circ}\right]$. 
When the crystal structure is expanded to view the overall packing of the crystal it can be seen that these bridging interactions propagate in two dimensions infinitely, in between layers of partial fluorine segregation (Figure S25d). This is analogous to the ionic core with hydrophobic segregation interlayers model described in KDESA. In comparison to KDESA, the ether side chains contribute more to stabilizing the interlayers. The segregation layer involves only $1 / 3$ of the available trifluoromethyl moieties, likely due to extensive coordination between the $\mathrm{K}$ and $\mathrm{F}$ atoms. Hydrophobic interactions between all three $\mathrm{C} 2, \mathrm{C} 3$, and $\mathrm{C} 4$ sites ensure a stable segregation layer.

The three unique MPSA anions (Figure S24e-g) also differ in their coordination. $2 / 3$ of the trifluoromethyl sulfonamide moieties are positioned deep within each layer, forming a core of highly ionic character, surrounding by a hydrophobic interlayer consisting of $1 / 3$ of the trifluoromethyls and all three nonequivalent ether side chains. Only ethers $\mathrm{O} 1$ and $\mathrm{O} 1$ ' coordinate to $\mathrm{K}$ sites, meaning $1 / 3$ of the ether $\mathrm{O}$ are uncoordinated. In addition, all 6 sulfonyl $\mathrm{O}$ sites are bridging, but 2/6 (O2' and $\mathrm{O} 3$ ) actually coordinate to $3 \mathrm{~K}$. In contrast only $\mathrm{N} 1$ is bridging, while $\mathrm{N} 1$ ' and $\mathrm{N} 1$ " coordinate to a single $\mathrm{K}$ each. Finally, the F of the MPSA anion have especially interesting coordination. The F1", F2" and F3" sites are all situated towards the hydrophobic interlayer, while the other two trifluoromethyls sit within the "ionic core" of each layer. The close proximity of these 2 trifluoromethyl sites to $\mathrm{K}$ cations results in CF-K coordination, specifically of F2, F3, and F2'.

Structure of KIPSA: There is only one unique site for each $\mathrm{K}$ cation and IPSA anion. Interestingly, each $\mathrm{K}$ is coordinated by only five atoms, resulting in a $\mathrm{K}$ cation which is seemingly unsaturated (Figure $\mathrm{S} 23 \mathrm{~h}$ ). These atoms include three sulfonyl $\mathrm{O}$, one $\mathrm{N}$ and one ether $\mathrm{O}$, from four different IPSA anions. Two $\mathrm{K}$ and two sulfonyl $\mathrm{O}$, from two different IPSA anions, form a planar K-O dimer. This is very similar to those found in KMPSA and $\mathrm{KPMEA}$. Due to the lack of coordinating atoms, there is only one chelation, a bidentate interaction through a sulfonyl $\mathrm{O}$ and a $\mathrm{N}$. The other 2 ISPA anions coordinate through a single atom, a sulfonyl and ether $\mathrm{O}$.

The packing of the KIPSA crystal follows the same segregated layers motif as KDESA and KMPSA (Figure S25e). The K-O dimers propagate in two dimensions in each ionic core region. They are connected to each other both the ether side chain as well as the sulfonyl O2 (Figure S30). Due to the larger size of the isopropoxy group compared to the methoxy in KDESA and KMPSA there are more side chain carbons involved in the stabilization of the hydrophobic interlayer.

The coordination environment of the IPSA anion is relatively simple (Figure S24h). All ether side chains are orientated towards the interlayer, yet all ether $\mathrm{O}$ are coordinated to a $\mathrm{K}$ cation as well. Sulfonyl $\mathrm{O} 3$ bridges two $\mathrm{K}$, while $\mathrm{O} 2$ only coordinates to one $\mathrm{K}$. Similarly, N1 only coordinates to a single $\mathrm{K}$ as well, however in a bidentate fashion with sulfonyl O3. The trifluoromethyl moieties are positioned squarely towards the interlayer and features no coordination to $\mathrm{K}$ at all, in contrast to DESA and MPSA. 


\section{Supplementary Crystal Data}

\begin{tabular}{|c|c|c|c|c|c|}
\hline Compound & KPMEA & KDESA & KMPSA & KIPSA & $\mathrm{KMTPA}^{*} 0.25 \mathrm{DCM}$ \\
\hline Formula & $\underset{2]}{\mathrm{K}\left[\mathrm{CF}_{3} \mathrm{SO}_{2} \mathrm{NC}_{6} \mathrm{H}_{13} \mathrm{O}\right.}$ & $\underset{2]}{\mathrm{K}\left[\mathrm{CF}_{3} \mathrm{SO}_{2} \mathrm{NC}_{4} \mathrm{H}_{10} \mathrm{O}\right.}$ & $\underset{]}{\mathrm{K}\left[\mathrm{CF}_{3} \mathrm{SO}_{2} \mathrm{NC}_{4} \mathrm{H}_{9} \mathrm{O}\right.}$ & $\begin{array}{c}\mathrm{K}\left[\mathrm{CF}_{3} \mathrm{SO}_{2} \mathrm{NC}_{6} \mathrm{H}_{13} \mathrm{O}\right. \\
]\end{array}$ & $\begin{array}{c}\mathrm{K}\left[\mathrm{CF}_{3} \mathrm{SO}_{2} \mathrm{NC}_{6} \mathrm{H}_{11} \mathrm{O}\right. \\
]^{*} 0.25 \mathrm{CH}_{2} \mathrm{Cl}_{2}\end{array}$ \\
\hline $\mathrm{M}_{\mathrm{w}}\left(\mathrm{g} \mathrm{mol}^{-1}\right)$ & 303.34 & 275.28 & 259.28 & 287.34 & 306.56 \\
\hline $\begin{array}{c}\text { Crystal Size } \\
\left(\mathrm{mm}^{3}\right)\end{array}$ & $\begin{array}{c}0.322 \times 0.215 \times \\
0.086 \\
\end{array}$ & $\begin{array}{c}0.257 \times 0.231 \times \\
0.095 \\
\end{array}$ & $\begin{array}{c}0.215 \times 0.137 \times \\
0.104 \\
\end{array}$ & $\begin{array}{c}0.596 \times 0.126 \times \\
0.103 \\
\end{array}$ & $\begin{array}{c}0.231 \times 0.065 \mathrm{x} \\
0.043 \\
\end{array}$ \\
\hline $\begin{array}{c}\text { Crystal } \\
\text { color, habit }\end{array}$ & Colorless plate & Colorless plate & Colorless block & Colorless needle & Colorless needle \\
\hline $\begin{array}{l}\text { Crystal } \\
\text { system }\end{array}$ & Triclinic & Triclinic & Triclinic & Monoclinic & Orthorhombic \\
\hline $\begin{array}{c}\text { Space } \\
\text { group (\#) }\end{array}$ & $\mathrm{P}-1(2)$ & $\mathrm{P}-1(2)$ & $\mathrm{P}-1(2)$ & $\mathrm{P} 2{ }_{1} / \mathrm{c}(14)$ & Fddd (70) \\
\hline $\mathbf{a}(\AA)$ & $6.4411(6)$ & $7.3440(5)$ & $10.2695(6)$ & $10.392(2)$ & $18.2533(14)$ \\
\hline b $(\AA)$ & $8.8961(10)$ & $7.7957(5)$ & $10.8187(6)$ & $11.488(2)$ & $32.815(3)$ \\
\hline$c(\AA)$ & $11.4897(12)$ & $9.1286(6)$ & 14.2434(9) & $10.990(2)$ & $32.965(3)$ \\
\hline$\alpha\left({ }^{\circ}\right)$ & $87.753(4)$ & $96.330(2)$ & $87.874(2)$ & 90 & 90 \\
\hline$\beta\left({ }^{\circ}\right)$ & 73.755(3) & $90.086(2)$ & $74.624(2)$ & $107.422(7)$ & 90 \\
\hline$Y\left({ }^{\circ}\right)$ & $81.989(3)$ & $95.585(2)$ & $86.247(2)$ & 90 & 90 \\
\hline$V\left(\AA^{3}\right)$ & $625.91(11)$ & $516.94(6)$ & $1522.24(16)$ & $1251.9(5)$ & $19745(3)$ \\
\hline Z & 2 & 2 & 6 & 4 & 64 \\
\hline $\begin{array}{c}\text { Temperatur } \\
\text { e (K) }\end{array}$ & $100(2)$ & $100(2)$ & $100(2)$ & $100(2)$ & $100(2)$ \\
\hline$\theta$ range $\left(^{\circ}\right)$ & 3.692 to 52.77 & 2.787 to 28.315 & 2.799 to 28.296 & 2.63 to 25.11 & 5.674 to 50.756 \\
\hline$\mu\left(\mathrm{mm}^{-1}\right)$ & 0.631 & 0.754 & 0.755 & 0.621 & 0.74 \\
\hline $\begin{array}{c}\text { Reflections } \\
\text { collected }\end{array}$ & 17555 & 15733 & 51901 & 2300 & 61277 \\
\hline $\begin{array}{l}\text { Independent } \\
\text { reflections }\end{array}$ & 2561 & 2560 & 7559 & 2300 & 4542 \\
\hline $\begin{array}{l}R_{1}, 1>2 \sigma(\mathrm{I}) \\
\text { (All data) }\end{array}$ & $0.0258(0.0281)$ & $0.0221(0.0276)$ & $0.0218(0.0277)$ & $0.0814(0.1583)$ & $0.0392(0.0639)$ \\
\hline $\begin{array}{c}w R_{2}, I>2 \sigma(\mathrm{I}) \\
\text { (All data) }\end{array}$ & $0.0608(0.0615)$ & $0.0508(0.0548)$ & $0.0508(0.0542)$ & $0.1689(0.1983)$ & $0.0940(0.1061)$ \\
\hline
\end{tabular}

Table S2. Crystallographic and diffraction information on KMPSA, KIPSA, KDESA, KMTPA, and KPMEA 


\begin{tabular}{|c|c|c|c|c|c|c|c|c|c|}
\hline \multicolumn{10}{|c|}{ Selected Bond Lengths $(\AA)$} \\
\hline \multicolumn{2}{|c|}{ KPMEA } & \multicolumn{2}{|l|}{ KDESA } & \multicolumn{2}{|l|}{ KMTPA } & \multicolumn{2}{|l|}{ KMPSA } & \multicolumn{2}{|l|}{ KIPSA } \\
\hline $\mathrm{K} 1-\mathrm{O} 1$ & $2.7317(13)$ & $\mathrm{K} 1-\mathrm{O} 1$ & $2.7326(10)$ & $\mathrm{K} 1-\mathrm{O} 2$ & $2.780(2)$ & $\mathrm{K} 1-\mathrm{O} 1$ & $2.7544(10)$ & $\mathrm{K} 1-\mathrm{O} 1$ & $2.668(5)$ \\
\hline $\mathrm{K} 1-\mathrm{O} 2$ & $2.6968(15)$ & $\mathrm{K} 1-\mathrm{O} 2$ & $2.8659(9)$ & K1-O2' & $2.809(2)$ & $\mathrm{K} 1-\mathrm{O} 2$ & $2.6627(9)$ & $\mathrm{K} 1-\mathrm{O} 2$ & $2.609(5)$ \\
\hline $\mathrm{K} 1-\mathrm{O} 3$ & $2.6898(14)$ & $\mathrm{K} 1-\mathrm{O} 3$ & $2.6896(9)$ & $\mathrm{K} 1-\mathrm{O} 3$ & $2.780(2)$ & $\mathrm{K} 1-\mathrm{O} 2$ & $2.9093(10)$ & $\mathrm{K} 1-\mathrm{O} 3$ & $2.829(5)$ \\
\hline $\mathrm{K} 1-\mathrm{O} 3$ & $2.7632(15)$ & $\mathrm{K} 1-\mathrm{O} 4$ & $2.7204(10)$ & $\mathrm{K} 1-\mathrm{N} 1$ & $2.833(3)$ & K1-O3 & $3.1730(10)$ & $\mathrm{K} 1-\mathrm{O} 3$ & $2.645(6)$ \\
\hline $\mathrm{K} 1-\mathrm{O} 4$ & $2.6940(15)$ & $\mathrm{K} 1-\mathrm{N} 1$ & $2.9635(11)$ & $\mathrm{K} 1-\mathrm{N} 1{ }^{\prime}$ & $2.842(3)$ & K1-O3" & $2.7951(10)$ & K1-N1 & $2.822(6)$ \\
\hline \multirow[t]{18}{*}{$\mathrm{K} 1-\mathrm{N} 1$} & $2.9202(17)$ & $\mathrm{K} 1-\mathrm{N} 1$ & $2.8811(11)$ & $\mathrm{K} 1-\mathrm{N} 1{ }^{\prime}$ & $3.057(3)$ & K1-N1" & $2.9108(12)$ & & \\
\hline & & K1-F2 & $2.9960(9)$ & $\mathrm{K} 11^{\prime}-\mathrm{O} 1$ & $2.654(2)$ & K1-F2' & $3.1266(11)$ & & \\
\hline & & & & $\mathrm{K} 11^{\prime}-\mathrm{O} 1$ & $2.654(2)$ & $\mathrm{K} 1-\mathrm{F} 3$ & $3.0786(9)$ & & \\
\hline & & & & K1'-O2' & $2.718(2)$ & K1'-O2' & $2.7471(9)$ & & \\
\hline & & & & K1'-O2' & $2.718(2)$ & K1'-O2' & $2.9972(10)$ & & \\
\hline & & & & K1'-O3 & $2.740(2)$ & K1'-O2" & $2.8277(10)$ & & \\
\hline & & & & K1'-O3 & $2.740(2)$ & K1'-O3 & $2.6924(9)$ & & \\
\hline & & & & K1"-O1' & $2.692(2)$ & K1'-O3 & $2.9405(10)$ & & \\
\hline & & & & K1"-O1' & $2.692(3)$ & K1'-O3" & $2.8301(10)$ & & \\
\hline & & & & K1"-O2 & $2.736(2)$ & K1'-N1 & $3.0082(11)$ & & \\
\hline & & & & K1"-O2 & $2.736(2)$ & K1'-N1' & $2.7844(11)$ & & \\
\hline & & & & K1"-O3' & $2.624(2)$ & K1"-O1' & $2.7562(10)$ & & \\
\hline & & & & K1"-O3' & $2.624(2)$ & K1"-O2' & $2.8721(10)$ & & \\
\hline & & & & & & K1"-O2" & $2.7097(10)$ & & \\
\hline & & & & & & K1"-O3' & $2.6975(9)$ & & \\
\hline & & & & & & K1"-O3' & $3.0006(10)$ & & \\
\hline & & & & & & K1"-N1 & $2.8830(11)$ & & \\
\hline & & & & & & K1"-F2 & $2.8826(8)$ & & \\
\hline $\mathrm{S} 1-\mathrm{O} 3$ & $1.4579(14)$ & S1-O1 & $1.4461(9)$ & $\mathrm{S} 1-\mathrm{O} 2$ & $1.447(2)$ & $\mathrm{S} 1-\mathrm{O} 2$ & $1.4526(9)$ & $\mathrm{S} 1-\mathrm{O} 2$ & $1.447(6)$ \\
\hline $\mathrm{S} 1-\mathrm{O} 4$ & $1.4519(15)$ & $\mathrm{S} 1-\mathrm{O} 2$ & $1.4448(10)$ & $\mathrm{S} 1-\mathrm{O} 3$ & $1.451(2)$ & $\mathrm{S} 1-\mathrm{O} 3$ & $1.4452(9)$ & $\mathrm{S} 1-\mathrm{O} 3$ & $1.436(6)$ \\
\hline \multirow[t]{7}{*}{ S1-N1 } & $1.5107(16)$ & S1-N1 & $1.5265(11)$ & S1-N1 & $1.508(3)$ & S1-N1 & $1.5197(11)$ & S1-N1 & $1.519(7)$ \\
\hline & & & & S1'-O2' & $1.448(2)$ & S1'-O2' & $1.4517(9)$ & & \\
\hline & & & & S1'-O3' & $1.439(2)$ & S1'-O3' & $1.4555(9)$ & & \\
\hline & & & & S1'-N1' & $1.518(3)$ & S1'-N1' & $1.5132(11)$ & & \\
\hline & & & & & & S1"-O2" & $1.4599(9)$ & & \\
\hline & & & & & & S1"-O3" & $1.4520(10)$ & & \\
\hline & & & & & & S1"-N1" & $1.5127(12)$ & & \\
\hline O1-C3 & $1.432(2)$ & O1-C2 & $1.4202(15)$ & O1-C4 & $1.437(4)$ & O1-C3 & $1.4277(16)$ & O1-C3 & $1.421(9)$ \\
\hline O1-C4 & $1.419(2)$ & O1-C3 & $1.4309(16)$ & O1-C5 & $1.426(4)$ & O1-C4 & $1.4222(17)$ & O1-C4 & $1.435(9)$ \\
\hline $\mathrm{O} 2-\mathrm{C} 5$ & $1.418(3)$ & $\mathrm{O} 2-\mathrm{C} 2$ & $1.4106(15)$ & $\mathrm{N} 1-\mathrm{C} 1$ & $1.482(4)$ & O1'-C3' & $1.4323(17)$ & $\mathrm{N} 1-\mathrm{C} 1$ & $1.448(11)$ \\
\hline O2-C6 & $1.422(3)$ & O2-C4 & $1.4301(16)$ & O1'-C4' & $1.429(4)$ & O1'-C4' & $1.4207(18)$ & & \\
\hline \multirow[t]{5}{*}{ N1-C1 } & $1.488(2)$ & $\mathrm{N} 1-\mathrm{C} 1$ & $1.4692(16)$ & O1'-C5' & $1.411(4)$ & O1"-C3" & $1.414(2)$ & & \\
\hline & & & & $\mathrm{N} 1{ }^{\prime}-\mathrm{C} 1{ }^{\prime}$ & $1.479(4)$ & O1"-C4" & $1.420(2)$ & & \\
\hline & & & & & & N1-C1 & $1.4759(16)$ & & \\
\hline & & & & & & N1"-C1" & $1.4790(18)$ & & \\
\hline & & & & & & N1'-C1' & $1.4743(17)$ & & \\
\hline
\end{tabular}

Table S3. Selected bond lengths from KPMEA, KDESA, KMTPA, KMPSA, and KISPA 


\begin{tabular}{|c|c|c|c|c|c|c|c|c|c|}
\hline \multicolumn{10}{|c|}{ Selected Bond Angles } \\
\hline \multicolumn{2}{|l|}{ KPMEA } & \multicolumn{2}{|l|}{ KDESA } & \multicolumn{2}{|l|}{ KMTPA } & \multicolumn{2}{|l|}{ KMPSA } & \multicolumn{2}{|l|}{ KIPSA } \\
\hline $\begin{array}{l}\text { O1 K1 } \\
\text { N1 }\end{array}$ & $102.30(4)$ & $\mathrm{N} 1 \mathrm{~K} 1 \mathrm{~F} 2$ & $105.17(3)$ & N1 K1 N1' & $119.61(8)$ & F2' K1 O3 & $64.61(3)$ & N1 K1 O3 & $50.76(17)$ \\
\hline $\mathrm{O} 1 \mathrm{~K} 1$ & & & & & & & & & \\
\hline $\mathrm{O} 3$ & $117.17(4)$ & $\mathrm{N} 1 \mathrm{~K} 1 \mathrm{~F} 2$ & $59.98(3)$ & $\mathrm{N} 1 \mathrm{~K} 1 \mathrm{~N} 1{ }^{\prime}$ & $131.70(8)$ & F3 K1 F2' & $112.02(2)$ & $\mathrm{O} 1 \mathrm{~K} 1 \mathrm{~N} 1$ & $116.46(19)$ \\
\hline $\begin{array}{l}\text { O1 K1 } \\
\text { S1 }\end{array}$ & $115.37(3)$ & $\begin{array}{l}\text { N1 K1 } \\
\text { N1 }\end{array}$ & $98.15(3)$ & $\mathrm{N} 1^{\prime} \mathrm{K} 1 \mathrm{~N} 1^{\prime}$ & $81.17(9)$ & F3 K1 O3 & $55.56(2)$ & $\begin{array}{l}\text { O1 K1 } \\
\text { O3 }\end{array}$ & $111.62(16)$ \\
\hline $\begin{array}{l}\mathrm{O} 2 \mathrm{~K} 1 \\
\mathrm{~N} 1\end{array}$ & $128.02(5)$ & $\begin{array}{l}\text { O1 K1 } \\
\text { F2 }\end{array}$ & $91.29(3)$ & O2' K1 N1' & $100.28(7)$ & N1" K1 F2' & $99.19(3)$ & $\mathrm{O} 2 \mathrm{~K} 1 \mathrm{~K} 1$ & $132.08(15)$ \\
\hline $\begin{array}{l}\mathrm{O} 2 \mathrm{~K} 1 \\
\mathrm{O} 1\end{array}$ & $62.68(4)$ & $\begin{array}{l}\text { O1 K1 } \\
\text { N1 }\end{array}$ & $151.45(3)$ & O2' K1 N1 & $127.08(7)$ & N1" K1 F3 & $122.80(3)$ & $\mathrm{O} 2 \mathrm{~K} 1 \mathrm{~N} 1$ & $102.9(2)$ \\
\hline $\begin{array}{l}\mathrm{O} 2 \mathrm{~K} 1 \\
\mathrm{O} 1\end{array}$ & $62.68(4)$ & $\begin{array}{l}\text { O1 K1 } \\
\text { N1 }\end{array}$ & $110.32(3)$ & $\mathrm{O} 2 \mathrm{~K} 1 \mathrm{~N} 1{ }^{\prime}$ & $144.03(8)$ & $\mathrm{N} 1 " \mathrm{~K} 1 \mathrm{O} 3$ & $104.01(3)$ & $\begin{array}{l}\mathrm{O} 2 \mathrm{~K} 1 \\
\mathrm{O} 1\end{array}$ & $109.00(17)$ \\
\hline $\begin{array}{l}\mathrm{O} 2 \mathrm{~K} 1 \\
\mathrm{O} 3\end{array}$ & $178.67(5)$ & $\begin{array}{l}\mathrm{O} 1 \mathrm{~K} 1 \\
\mathrm{O} 2\end{array}$ & $94.32(3)$ & O2' K1 N1' & $50.68(7)$ & O1 K1 F2' & $142.39(3)$ & $\begin{array}{l}\mathrm{O} 2 \mathrm{~K} 1 \\
\mathrm{O} 3\end{array}$ & $105.33(18)$ \\
\hline $\begin{array}{l}\text { O3 K1 } \\
\text { N1 }\end{array}$ & $123.29(5)$ & $\begin{array}{l}\mathrm{O} 2 \mathrm{~K} 1 \\
\mathrm{~F} 2\end{array}$ & $116.29(3)$ & $\mathrm{O} 2 \mathrm{~K} 1 \mathrm{~N} 1$ & $51.15(7)$ & $\mathrm{O} 1 \mathrm{~K} 1 \mathrm{~F} 3$ & $99.69(3)$ & $\begin{array}{l}\text { O2 K1 } \\
\text { O3 }\end{array}$ & $138.53(18)$ \\
\hline $\begin{array}{l}\text { O3 K1 } \\
\text { N1 }\end{array}$ & $50.65(4)$ & $\begin{array}{l}\mathrm{O} 2 \mathrm{~K} 1 \\
\mathrm{~K} 1\end{array}$ & $74.22(2)$ & $\mathrm{O} 2 \mathrm{~K} 1 \mathrm{~N} 1{ }^{\prime}$ & $85.61(7)$ & O1 K1 N1" & $78.81(3)$ & $\mathrm{O} 3 \mathrm{~K} 1 \mathrm{~N} 1$ & $127.65(17)$ \\
\hline $\begin{array}{l}\text { O3 K1 } \\
\text { O1 }\end{array}$ & $77.52(4)$ & $\begin{array}{l}\mathrm{O} 2 \mathrm{~K} 1 \\
\mathrm{~N} 1\end{array}$ & $98.82(3)$ & O2 K1 O2' & $165.28(7)$ & $\mathrm{O} 1 \mathrm{~K} 1 \mathrm{O} 2$ & $133.02(3)$ & $\begin{array}{l}\mathrm{O} 3 \mathrm{~K} 1 \\
\mathrm{O} 1\end{array}$ & $94.50(17)$ \\
\hline $\begin{array}{l}\mathrm{O} 3 \mathrm{~K} 1 \\
\mathrm{O} 2\end{array}$ & $102.67(5)$ & $\begin{array}{l}\mathrm{O} 2 \mathrm{~K} 1 \\
\mathrm{~N} 1\end{array}$ & $58.72(3)$ & O2 K1 O3 & $92.10(7)$ & $\mathrm{O} 1 \mathrm{~K} 1 \mathrm{O} 3$ & $152.75(3)$ & $\begin{array}{l}\text { O3 K1 } \\
\text { O3 }\end{array}$ & $79.62(17)$ \\
\hline $\begin{array}{l}\text { O3 K1 } \\
\text { O3 }\end{array}$ & $78.51(5)$ & $\begin{array}{l}\text { O3 K1 } \\
\text { F2 }\end{array}$ & $90.52(3)$ & O3 K1 N1' & $100.05(7)$ & O1 K1 O3" & $98.94(3)$ & & \\
\hline $\begin{array}{l}\text { O3 K1 } \\
\text { O3 }\end{array}$ & $78.51(5)$ & $\begin{array}{l}\text { O3 K1 } \\
\text { N1 }\end{array}$ & $147.82(3)$ & $\mathrm{O} 3 \mathrm{~K} 1 \mathrm{~N} 1$ & $101.71(7)$ & O2 K1 F2' & $59.01(3)$ & & \\
\hline $\begin{array}{l}\text { O3 K1 } \\
\text { O4 }\end{array}$ & $112.40(5)$ & $\begin{array}{l}\text { O3 K1 } \\
\text { N1 }\end{array}$ & $76.13(3)$ & O3 K1 N1' & $123.04(7)$ & O2 K1 F2' & $62.18(3)$ & & \\
\hline $\begin{array}{l}\mathrm{O} 4 \mathrm{~K} 1 \\
\mathrm{~N} 1\end{array}$ & $99.40(5)$ & $\begin{array}{l}\text { O3 K1 } \\
\text { O1 }\end{array}$ & $80.65(3)$ & O3 K1 O2' & $73.66(6)$ & O2 K1 F3 & $57.69(2)$ & & \\
\hline $\begin{array}{l}\mathrm{O} 4 \mathrm{~K} 1 \\
\mathrm{O} 1\end{array}$ & $144.85(5)$ & $\begin{array}{l}\mathrm{O} 3 \mathrm{~K} 1 \\
\mathrm{O} 2\end{array}$ & $152.94(3)$ & $\mathrm{O} 1 \mathrm{~K} 1^{\prime} \mathrm{O} 1$ & $92.64(11)$ & $\mathrm{O} 2 \mathrm{~K} 1 \mathrm{~F} 3$ & $121.05(3)$ & & \\
\hline $\begin{array}{l}\mathrm{O} 4 \mathrm{~K} 1 \\
\mathrm{O} 2\end{array}$ & $82.17(5)$ & $\begin{array}{l}\text { O3 K1 } \\
\text { O4 }\end{array}$ & $84.47(3$ & $\mathrm{O} 1 \mathrm{~K} 1^{\prime} \mathrm{O} 2^{\prime}$ & $177.32(7)$ & O2 K1 N1" & $115.75(3)$ & & \\
\hline $\begin{array}{l}\text { O4 K1 } \\
\text { O3 }\end{array}$ & $97.97(5)$ & $\begin{array}{l}\mathrm{O} 4 \mathrm{~K} 1 \\
\mathrm{~F} 2\end{array}$ & $155.84(3)$ & O1 K1' O2' & $177.32(7)$ & O2 K1 N1" & $148.00(3)$ & & \\
\hline & & $\begin{array}{l}\text { O4 K1 } \\
\text { N1 }\end{array}$ & $116.74(3)$ & O1 K1' O2' & $87.77(7)$ & O2 K1 O1 & $84.62(3)$ & & \\
\hline & & $\begin{array}{l}\mathrm{O} 4 \mathrm{~K} 1 \\
\mathrm{~N} 1\end{array}$ & $50.69(3)$ & O1 K1' O2' & $87.77(7)$ & $\mathrm{O} 2 \mathrm{~K} 1 \mathrm{O} 2$ & $76.75(3)$ & & \\
\hline & & $\begin{array}{l}\text { O4 K1 } \\
\text { O1 }\end{array}$ & $111.06(3)$ & $\mathrm{O} 1 \mathrm{~K} 1{ }^{\prime} \mathrm{O} 3$ & $101.58(7)$ & $\mathrm{O} 2 \mathrm{~K} 1 \mathrm{O} 3$ & $116.73(3)$ & & \\
\hline & & $\begin{array}{l}\text { O4 K1 } \\
\text { O2 }\end{array}$ & $72.48(3)$ & O1 K1' O3 & $101.58(7)$ & $\mathrm{O} 2 \mathrm{~K} 1 \mathrm{O} 3$ & $47.12(2)$ & & \\
\hline & & & & $\mathrm{O} 1 \mathrm{~K} 1{ }^{\prime} \mathrm{O} 3$ & $102.43(7)$ & O2 K1 O3" & $164.15(3)$ & & \\
\hline & & & & $\mathrm{O} 1 \mathrm{~K} 11^{\prime} \mathrm{O} 3$ & $102.44(7)$ & O3" K1 F2' & $108.69(3)$ & & \\
\hline & & & & O2' K1' O2' & $91.93(10)$ & O3" K1 F3 & $73.79(3)$ & & \\
\hline & & & & O2' K1' O3 & $75.74(7)$ & O3" K1 N1" & $50.73(3)$ & & \\
\hline & & & & O2' K1' O3 & $75.75(7)$ & O3" K1 O2 & $110.59(3)$ & & \\
\hline & & & & O2' K1' O3 & $80.06(7)$ & O3" K1 O3 & $65.41(3)$ & & \\
\hline & & & & O2' K1' O3 & $80.07(7)$ & O3" K1' O3 & $164.43(3)$ & & \\
\hline
\end{tabular}




\begin{tabular}{|c|c|c|c|}
\hline \multirow{2}{*}{$\begin{array}{l}\text { O3 K1' O3 } \\
\text { O1' K1" } \\
\text { O1' }\end{array}$} & $144.94(10)$ & N1' K1' N1 & $105.20(3)$ \\
\hline & $71.98(11)$ & N1' K1' O2' & 49.77(3) \\
\hline O1' K1" O2 & $104.02(7)$ & N1' K1' O2" & $126.20(3)$ \\
\hline O1' K1" O2 & $104.02(7)$ & N1' K1' O3 & $93.64(3)$ \\
\hline O1' K1" O2 & $163.51(7)$ & N1' K1' O3" & $101.89(3)$ \\
\hline O1' K1" O2 & $163.51(7)$ & $\mathrm{O} 2^{\prime} \mathrm{K} 1{ }^{\prime} \mathrm{N} 1$ & $106.53(3)$ \\
\hline \multirow{2}{*}{$\begin{array}{l}\text { O2 K1" O2 } \\
\text { O3' K1" } \\
\text { O1' }\end{array}$} & $84.16(10)$ & O2' K1' N1 & $77.50(3)$ \\
\hline & $81.60(8)$ & $\mathrm{O} 2^{\prime} \mathrm{K} 1^{\prime} \mathrm{N} 1^{\prime}$ & $156.39(3)$ \\
\hline \multicolumn{4}{|l|}{ O3' K1" } \\
\hline \multicolumn{4}{|l|}{ O3' K1" } \\
\hline \multicolumn{3}{|l|}{ O3' K1" } & $70.24(3)$ \\
\hline O3' K1" O2 & $83.09(7)$ & O2' K1' O3" & $94.59(3)$ \\
\hline O3' K1" O2 & $83.09(7)$ & O2" K1' N1 & $75.32(3)$ \\
\hline O3' K1" O2 & $98.13(7)$ & O2" K1' O2' & $175.75(3)$ \\
\hline \multirow{26}{*}{$\begin{array}{l}\text { O3' K1" O2 } \\
\text { O3' K1" } \\
\text { O3' }\end{array}$} & $98.14(7)$ & O2" K1' O3 & $119.22(3)$ \\
\hline & $178.36(12)$ & O2" K1' O3" & $51.34(3)$ \\
\hline & & O3 K1' N1 & $144.87(3)$ \\
\hline & & O3 K1' N1 & $48.63(3)$ \\
\hline & & O3 K1' N1' & $98.44(3)$ \\
\hline & & O3 K1' O2' & $70.66(3)$ \\
\hline & & O3 K1' O2' & $70.07(3)$ \\
\hline & & O3 K1' O2' & $63.98(3)$ \\
\hline & & O3 K1' O2" & $110.72(3)$ \\
\hline & & O3 K1' O3 & $105.00(2)$ \\
\hline & & O3 K1' O3" & $71.81(3)$ \\
\hline & & O3" K1' N1 & $126.30(3)$ \\
\hline & & O3" K1' O2' & $126.25(3)$ \\
\hline & & F2 K1" C1 & $145.04(3)$ \\
\hline & & F2 K1" N1 & $154.27(3)$ \\
\hline & & F2 K1" O3' & $62.74(3)$ \\
\hline & & N1 K1" C1 & $24.85(3)$ \\
\hline & & N1 K1" O3' & $107.36(3)$ \\
\hline & & O1' K1" C1 & $86.76(3)$ \\
\hline & & O1' K1" F2 & $76.77(3)$ \\
\hline & & O1' K1" N1 & $111.04(3)$ \\
\hline & & O1' K1" O2' & $153.80(3)$ \\
\hline & & O1' K1" O3' & $139.33(3)$ \\
\hline & & O2' K1" C1 & $101.88(3)$ \\
\hline & & O2' K1" F2 & $106.46(3)$ \\
\hline & & O2' K1" N1 & $77.65(3)$ \\
\hline
\end{tabular}




\begin{tabular}{ll} 
O2' K1" O3' & $49.04(2)$ \\
\hline O2" K1" C1 & $79.36(3)$ \\
\hline O2" K1" F2 & $126.49(3)$ \\
O2" K1" N1 & $79.23(3)$ \\
\hline O2" K1" O1' & $80.24(3)$ \\
O2" K1" O2' & $77.21(3)$ \\
\hline O2" K1" O3' & $120.32(3)$ \\
O3' K1" C1 & $76.08(3)$ \\
O3' K1" C1 & $129.02(3)$ \\
O3' K1" F2 & $71.67(3)$ \\
O3' K1" N1 & $84.57(3)$ \\
\hline O3' K1" O1' & $83.73(3)$ \\
O3' K1" O2' & $122.26(3)$ \\
O3' K1" O2" & $151.28(3)$ \\
O3' K1" O3' & $87.06(3)$
\end{tabular}

Table S4. Selected bond angles from KPMEA, KDESA, KMTPA, KMPSA, and KIPSA 


\section{Supplementary Crystal Pictures}

\section{K-Ion Coordination}

a)
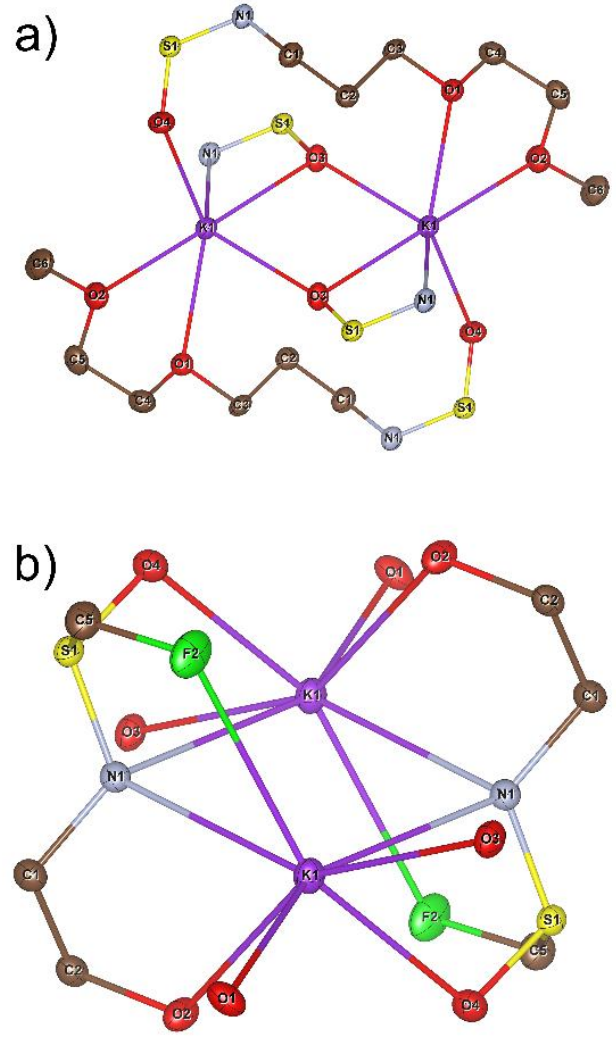

b)

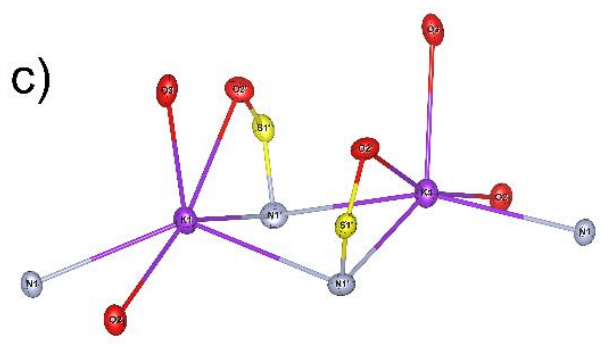

d)

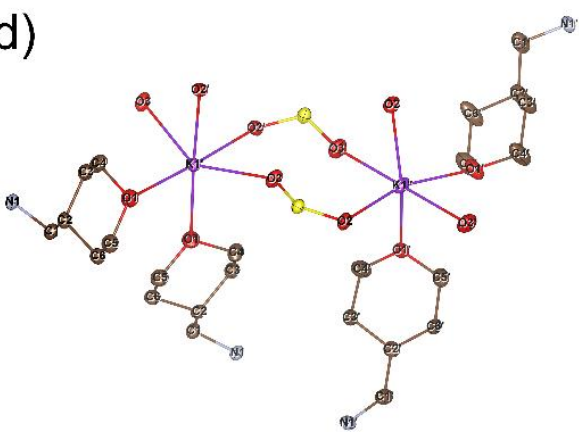

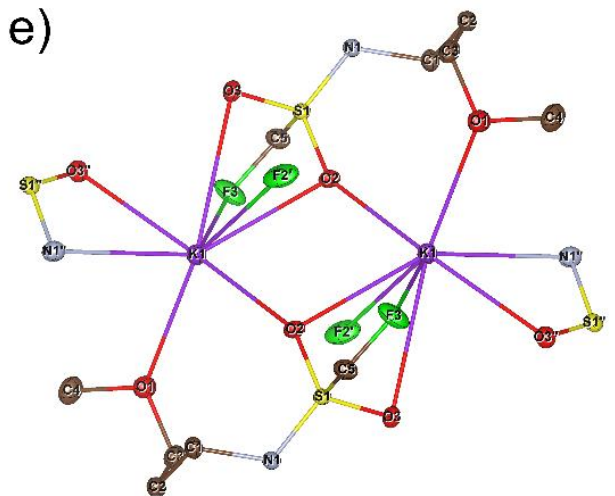
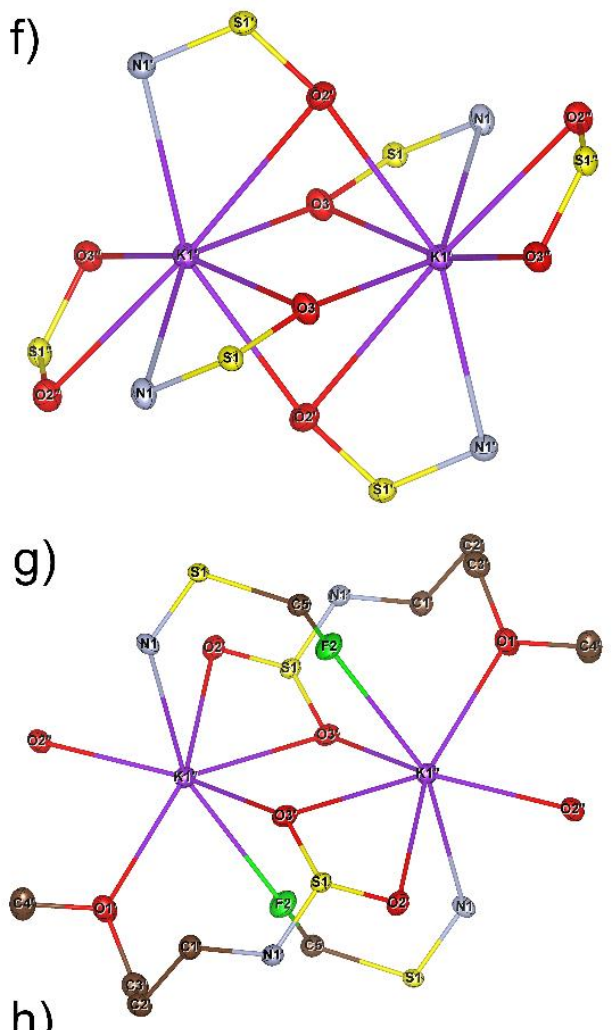

h)

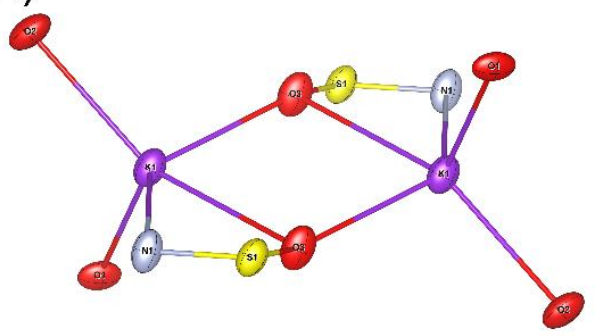

Figure S23. K coordination structures for each A-TFSA salt, atoms uninvolved in coordination structures omitted, thermal ellipsoids at 50\%, all crystal structure figures drawn in VESTA ${ }^{1}$ (a) Nearest neighbor K1 sites in KPMEA (b) Nearest neighbor K1 in KDESA c) Nearest neighbor K1 sites in KMTPA (d) Nearest neighbor K1' and K1" sites in KMTPA (e) Nearest neighbor K1 sites in KMPSA (f) Nearest neighbor K1' sites in KMPSA (g) Nearest neighbor K1" sites in KMPSA (h) Nearest neighbor K1 sites in KIPSA Color key: Purple $=\mathrm{K}$, Red $=\mathrm{O}$, Blue $=\mathrm{N}$, Brown $=\mathrm{C}$, Light green $=\mathrm{F}$, Yellow $=\mathrm{S}$ 


\section{Anion Coordination}
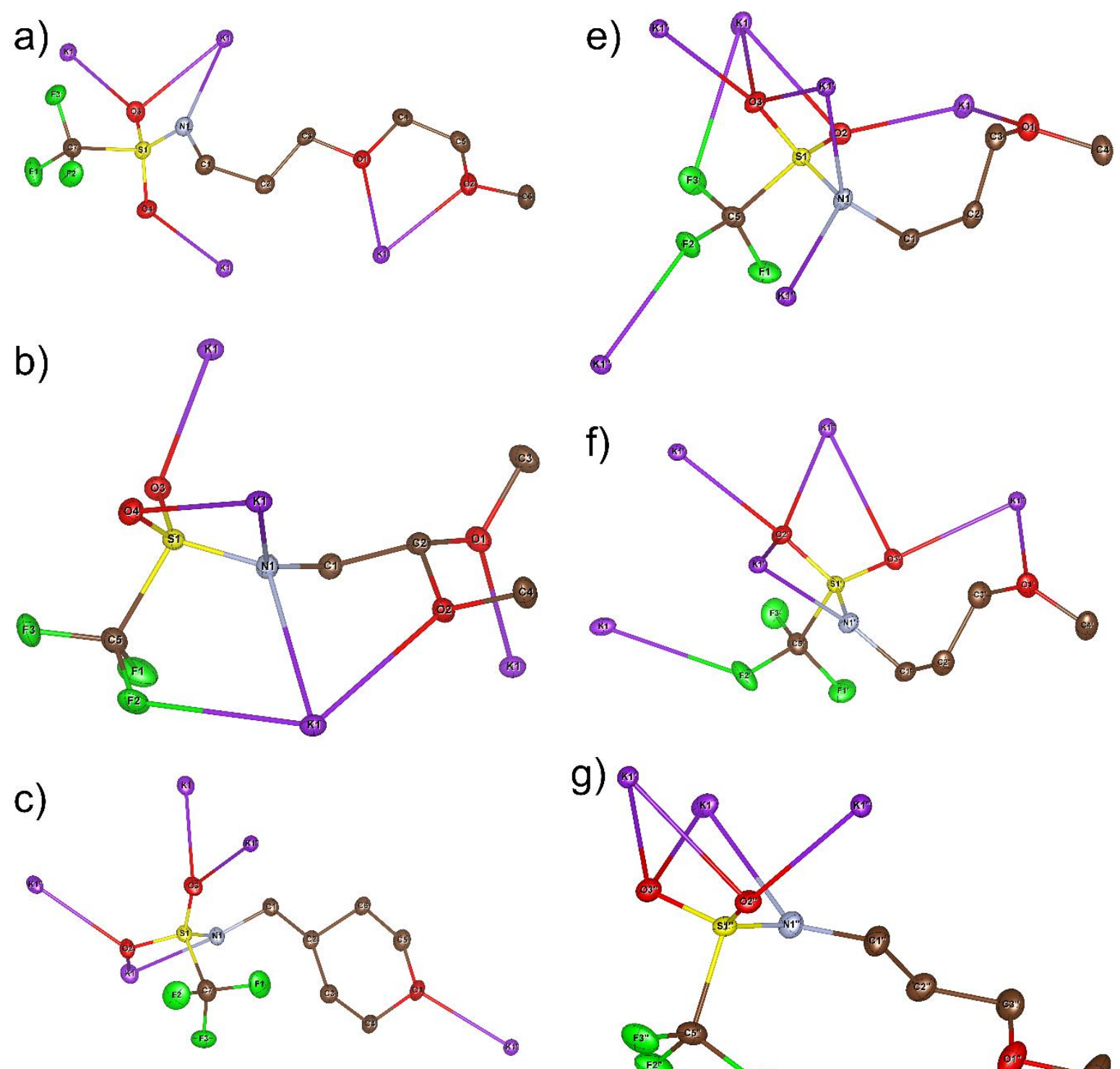

g)
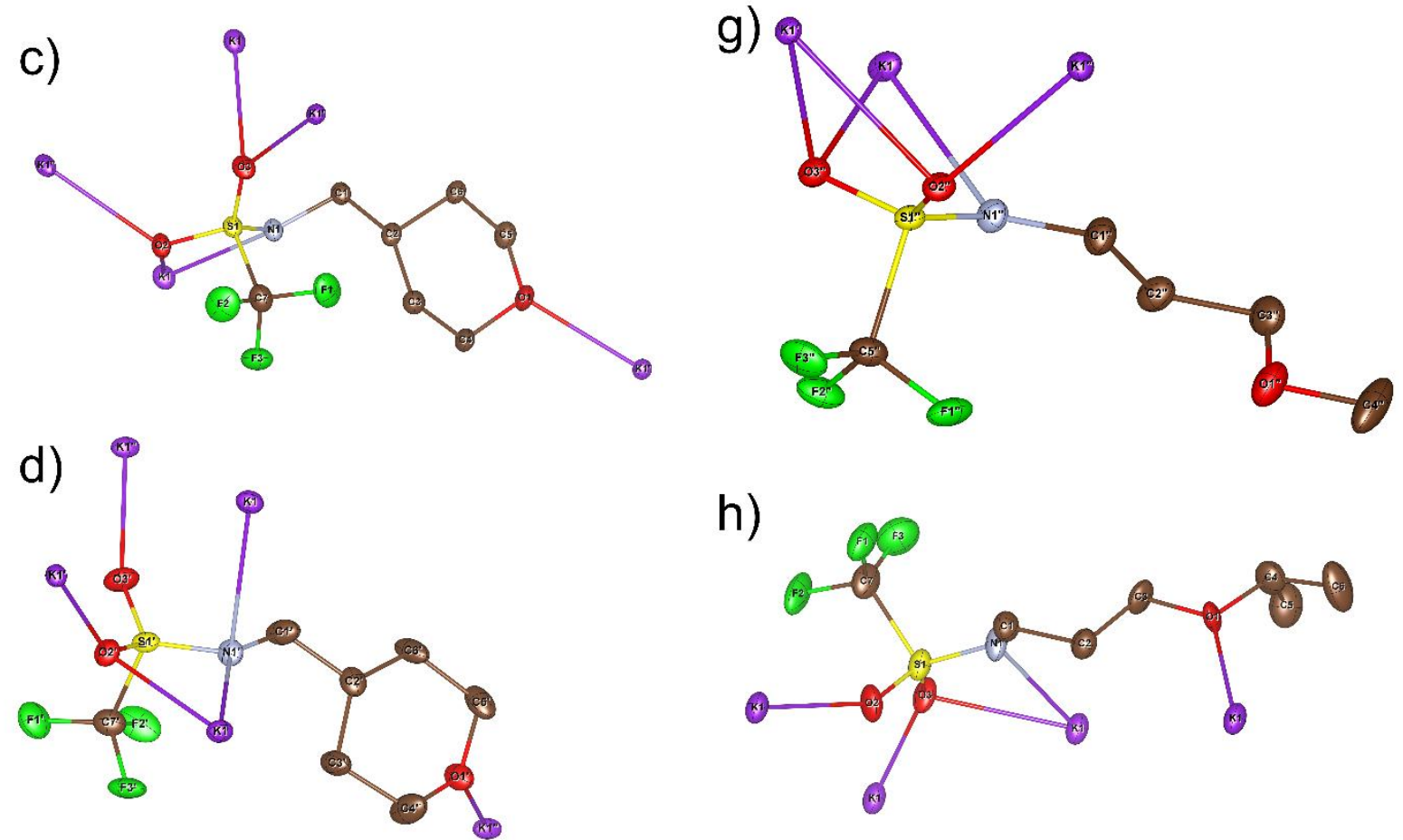

h)

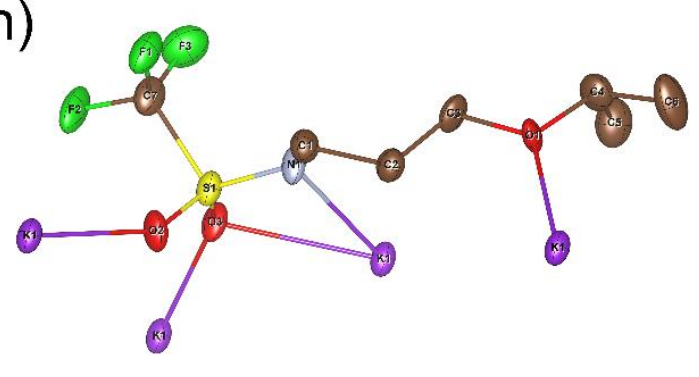

Figure S24. Anion coordination for each anion site in every A-TFSA crystal structure, thermal ellipsoids at $50 \%$ (a) Anion PMEA1 coordinating to four $\mathrm{K}$ sites (b) Anion DESA1 coordinating to four $\mathrm{K}$ sites (c) Anion MTPA1 coordinating to five K sites (d) Anion MTPA1' coordinating to five K sites (e) Anion MPSA1 coordinating to six K sites (f) Anion MPSA1' coordinating to three K sites (g) Anion MPSA1" coordinating to five $\mathrm{K}$ sites $(\mathbf{h})$ Anion IPSA1 coordinating to four $\mathrm{K}$ sites 


\section{Crystal Packing}

a)
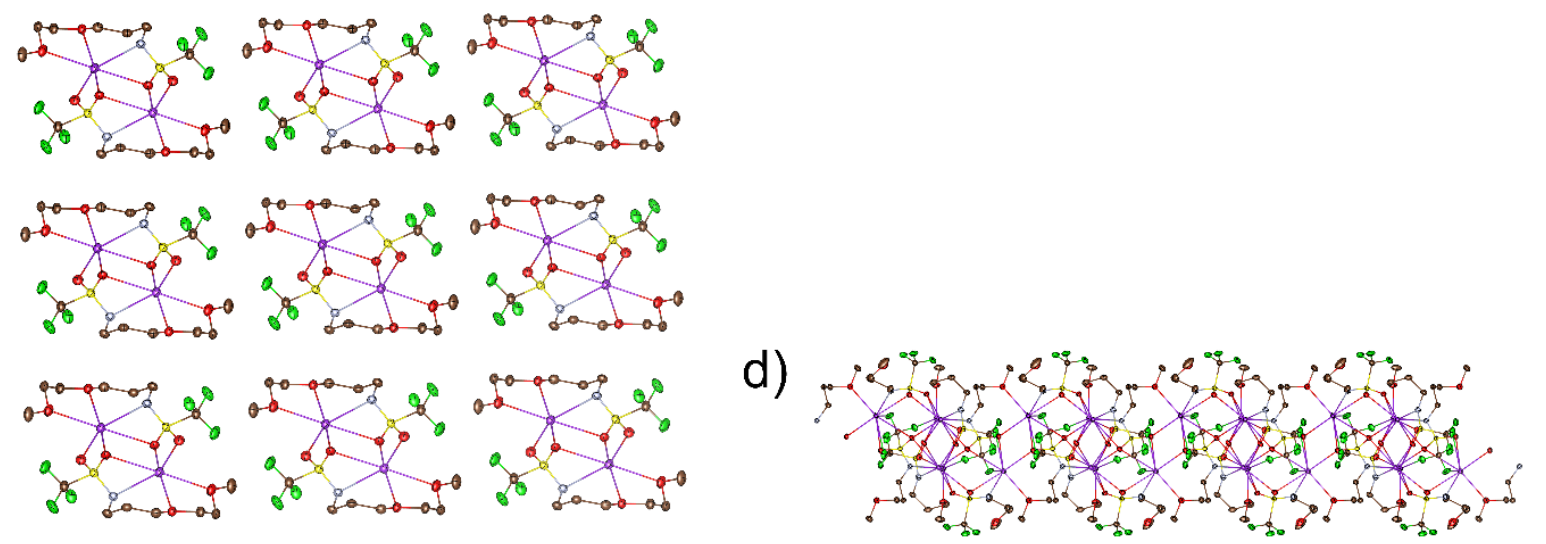

b)
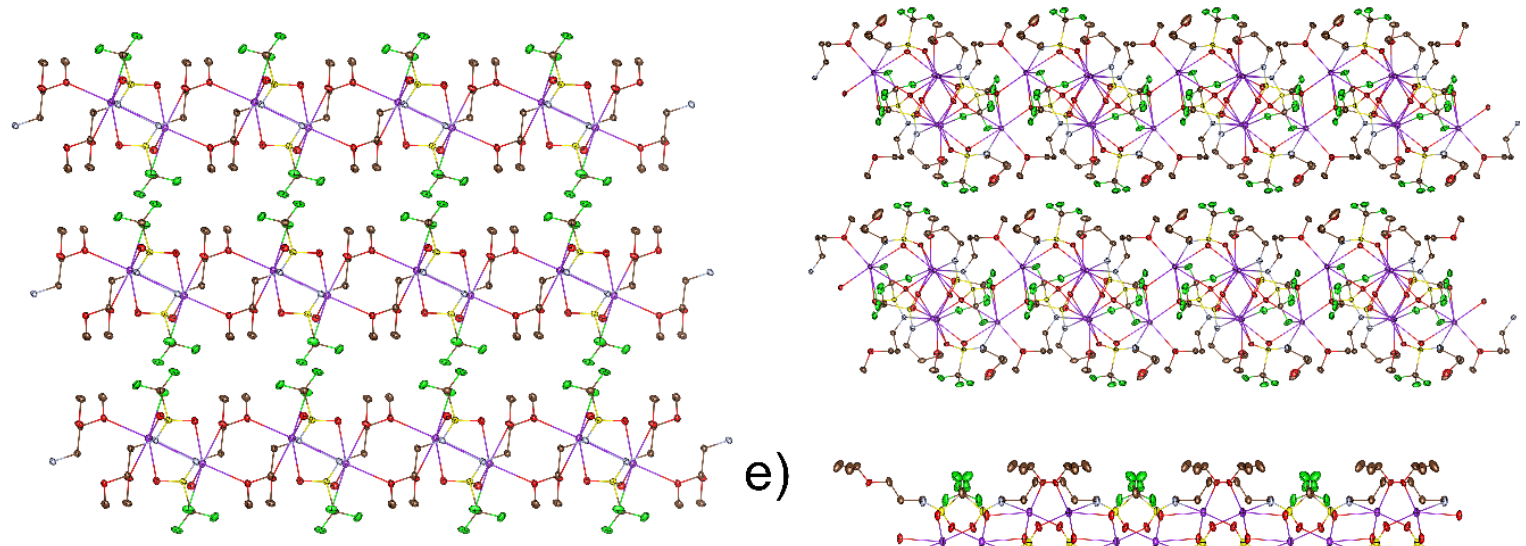

e)

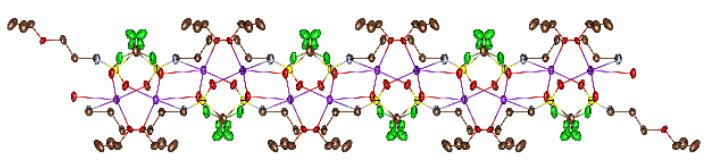

c)

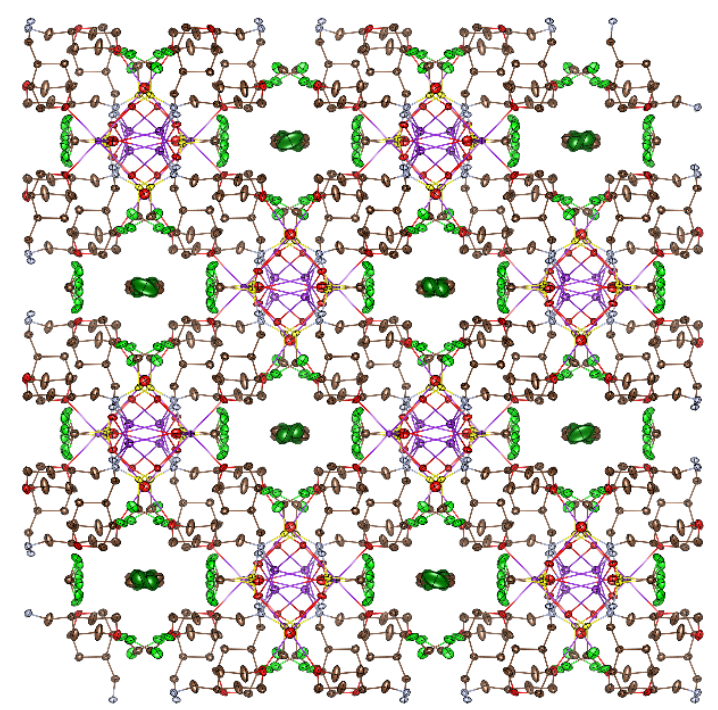

on

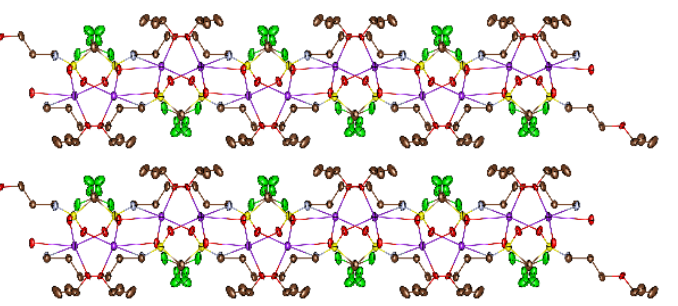

Figure S25. Packing diagrams of each A-TFSA salt showing the long-range ordering, thermal ellipsoids at $50 \%$ (a) Nearest neighbor K1 dimers, atoms uninvolved in coordination structures omitted for clarity, thermal ellipsoids at $50 \%$ b) Nearest neighbor K1' and K1" sites, atoms uninvolved in coordination structures omitted for clarity, thermal ellipsoids at $50 \%$ c) Crystal packing of KMTPA, note the DCM molecules within the segregated tunnels, each site displays both possible positions for each DCM site, thermal ellipsoids at $50 \%$ Color Key: Dark green $=\mathrm{Cl}$ 


\section{KPMEA}

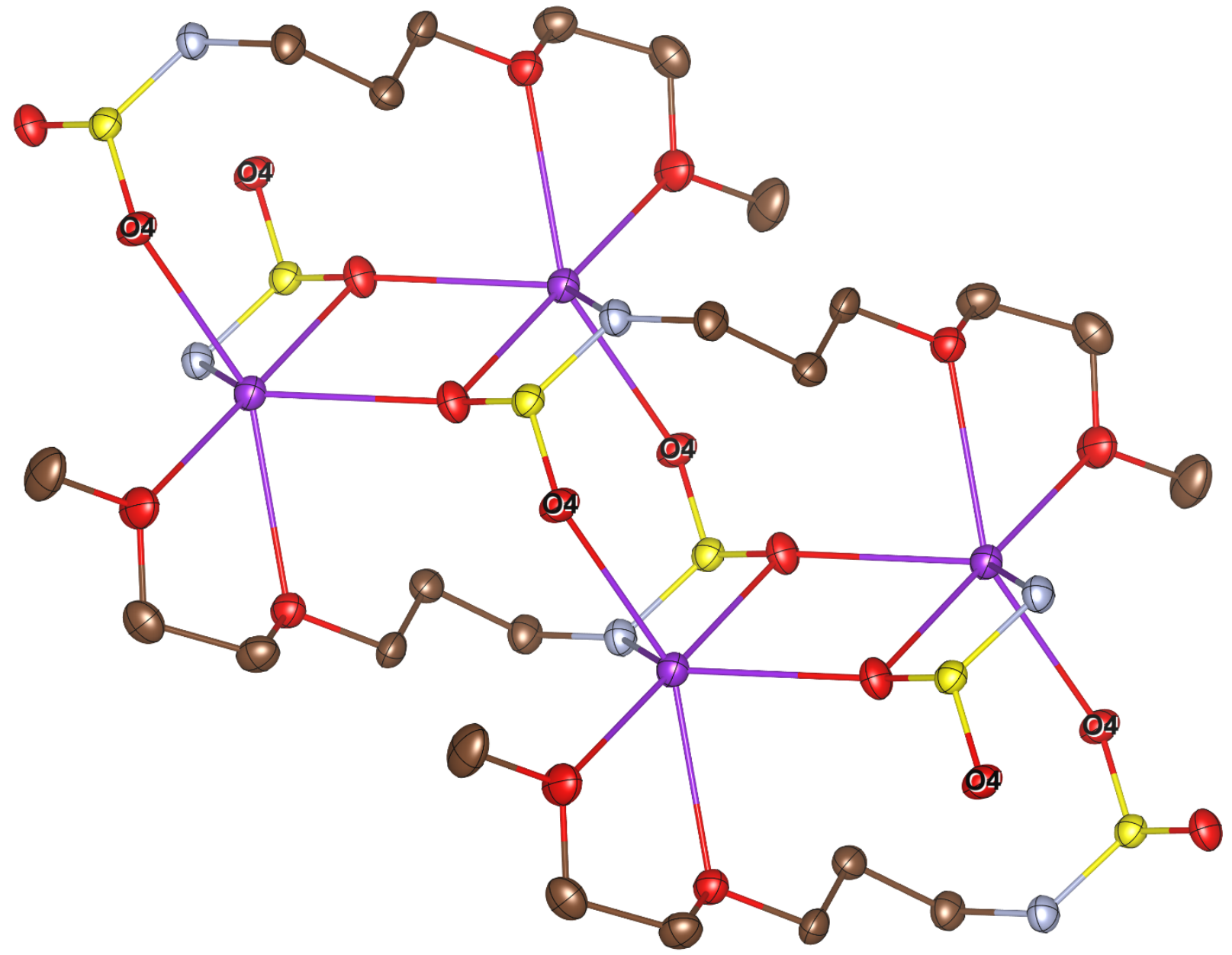

Figure S26. Nearest neighbor K-O dimers in KPMEA structure, labeled $\mathrm{O} 4$ connect each $\mathrm{K}-\mathrm{O}$ dimer through infinite $1-D$ chains along a-axis, hydrogen atoms omitted for clarity, thermal ellipsoids at $50 \%$ 


\section{KDESA}

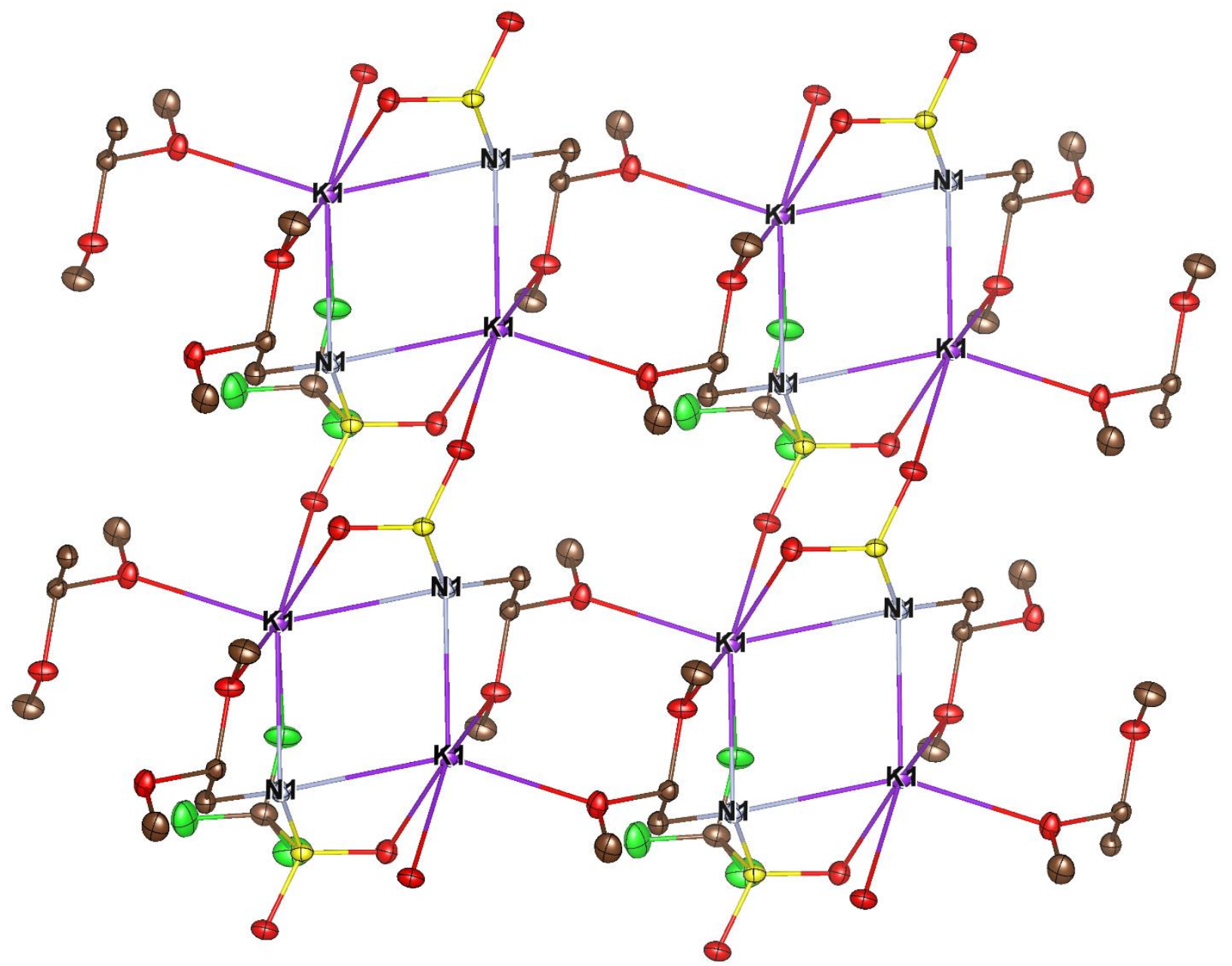

Figure S27. Four nearest neighbor K-N dimers in KDESA structure (labeled), showing connection through ether side chains and sulfonyl moieties between nearest neighbor $\mathrm{K}$ dimers, $1 / 2$ of trifluoromethyl groups omitted for clarity, thermal ellipsoids at $50 \%$ 


\section{KMTPA}

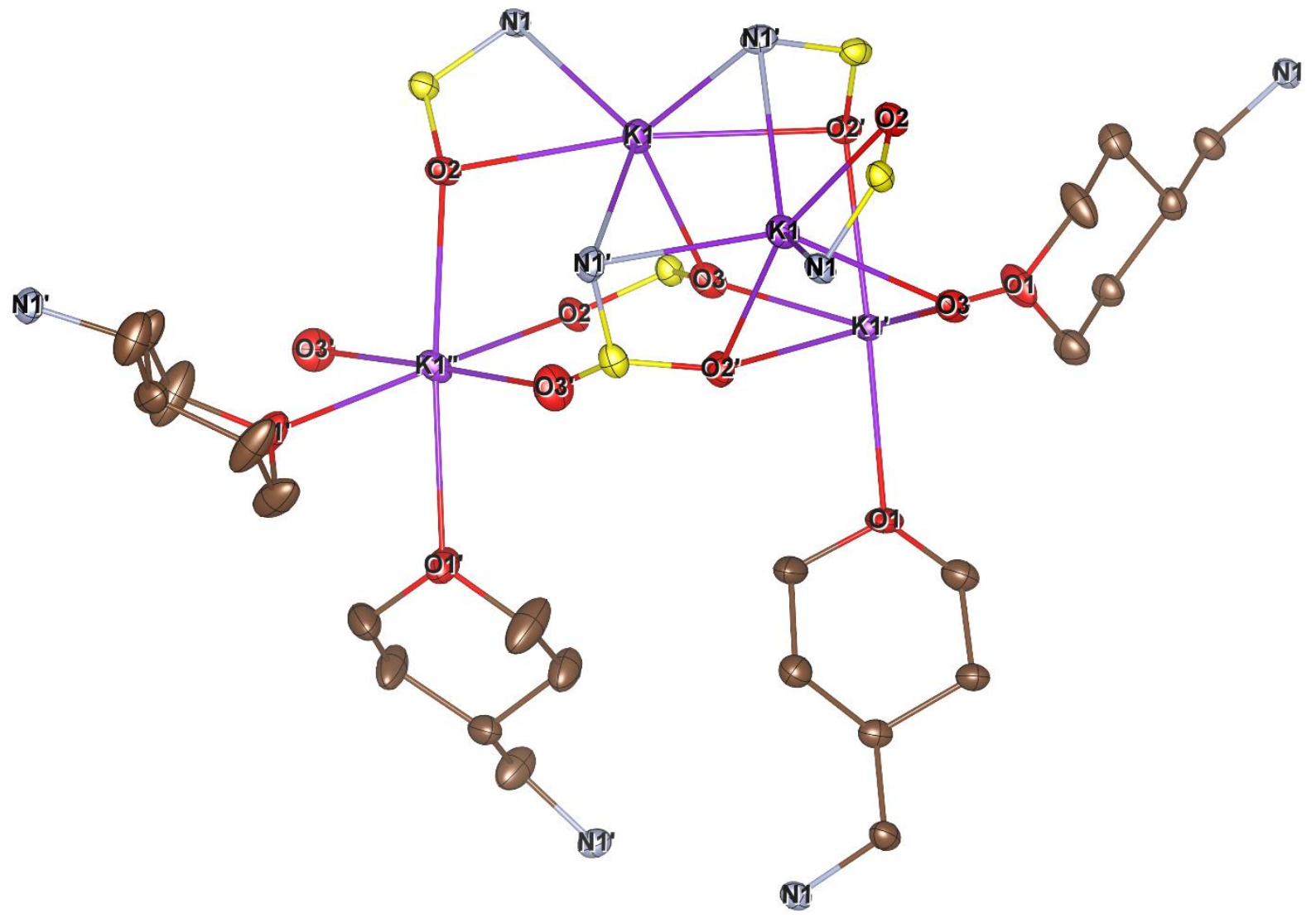

Figure S28. Nearest neighbor K cluster in KMTPA structure, featuring 2 K1, $1 \mathrm{~K} 1$ ' and $1 \mathrm{~K} 1$ " sites, trifluoromethyls and hydrogens omitted for clarity, thermal ellipsoids at $50 \%$, 


\section{KMPSA}

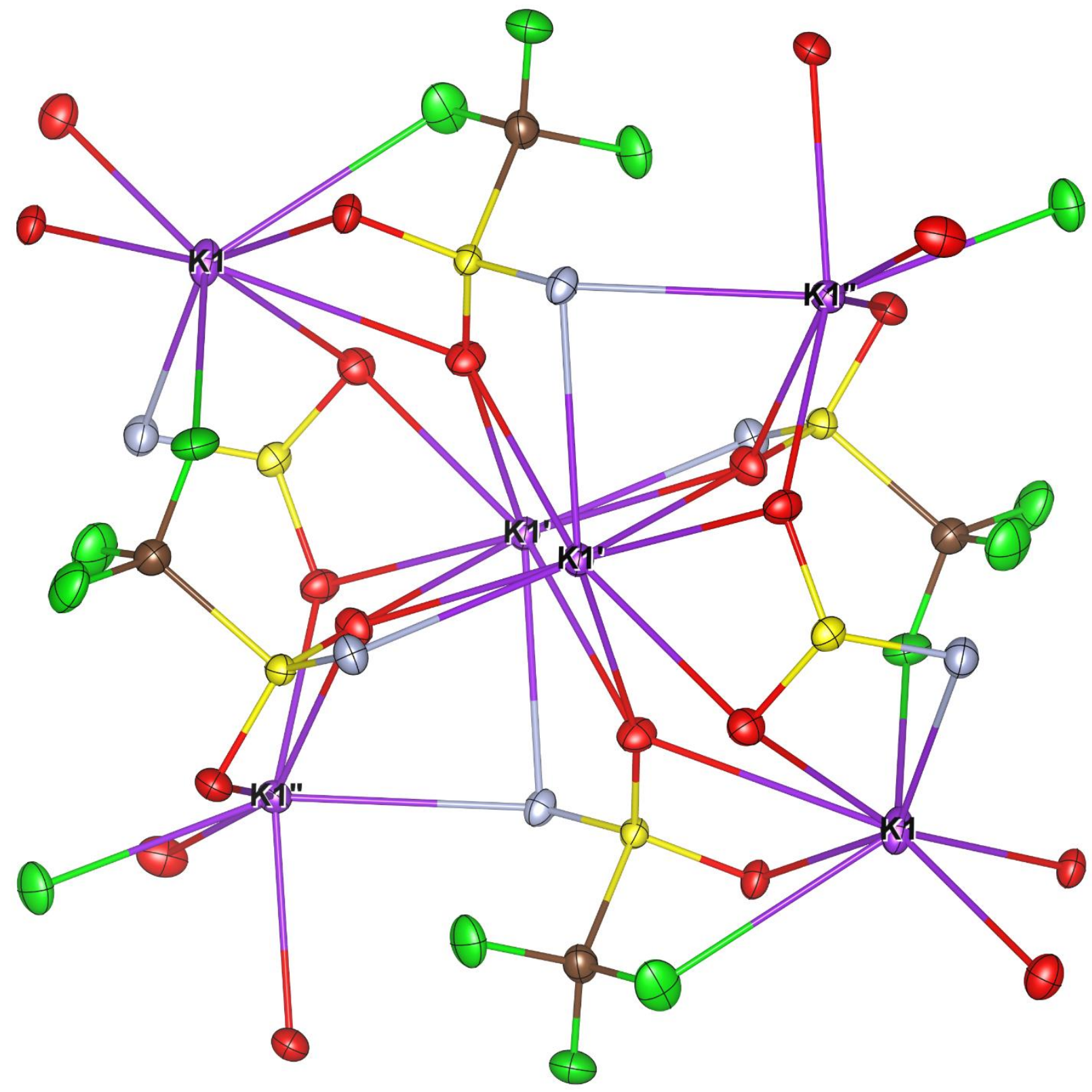

Figure S29. Nearest neighbors K cluster in KMPSA structure, showing K-O dimers between K1 and K1', $\mathrm{K} 1$ ' and $\mathrm{K} 1$ ', and $\mathrm{K}-\mathrm{O}-\mathrm{K}-\mathrm{N}$ bridging interaction between $\mathrm{K} 1$ ' and $\mathrm{K} 1$ ', hydrogen atoms omitted for clarity, thermal ellipsoids at $50 \%$ 


\section{KIPSA}

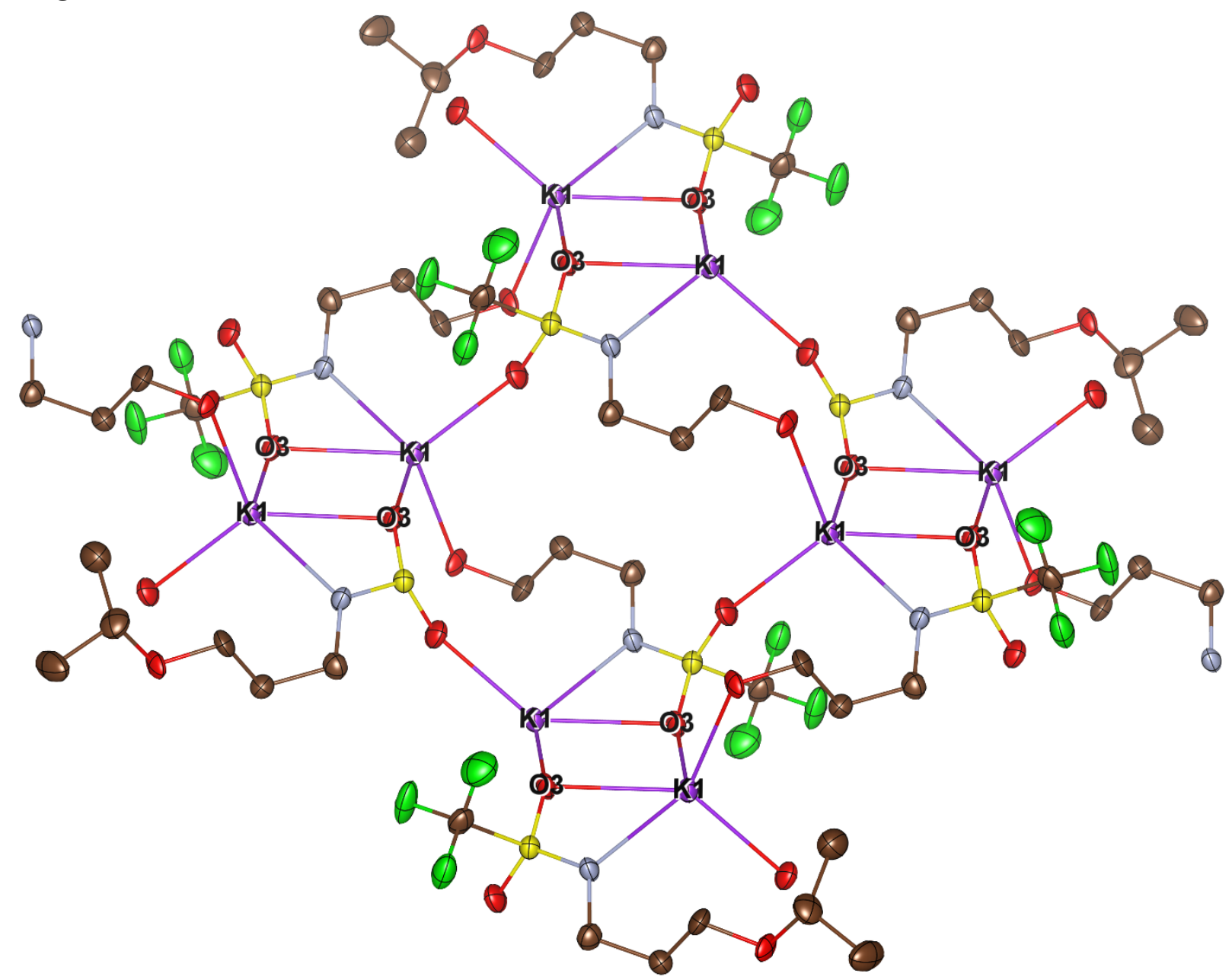

Figure S30. Four nearest K-O dimers in KIPSA structure, showing ether side connection between dimers, forming infinite 2-D plain, some isopropoxy and trifluoromethyl and all hydrogen atoms omitted for clarity, thermal ellipsoids at $50 \%$. 
65

KTFSI

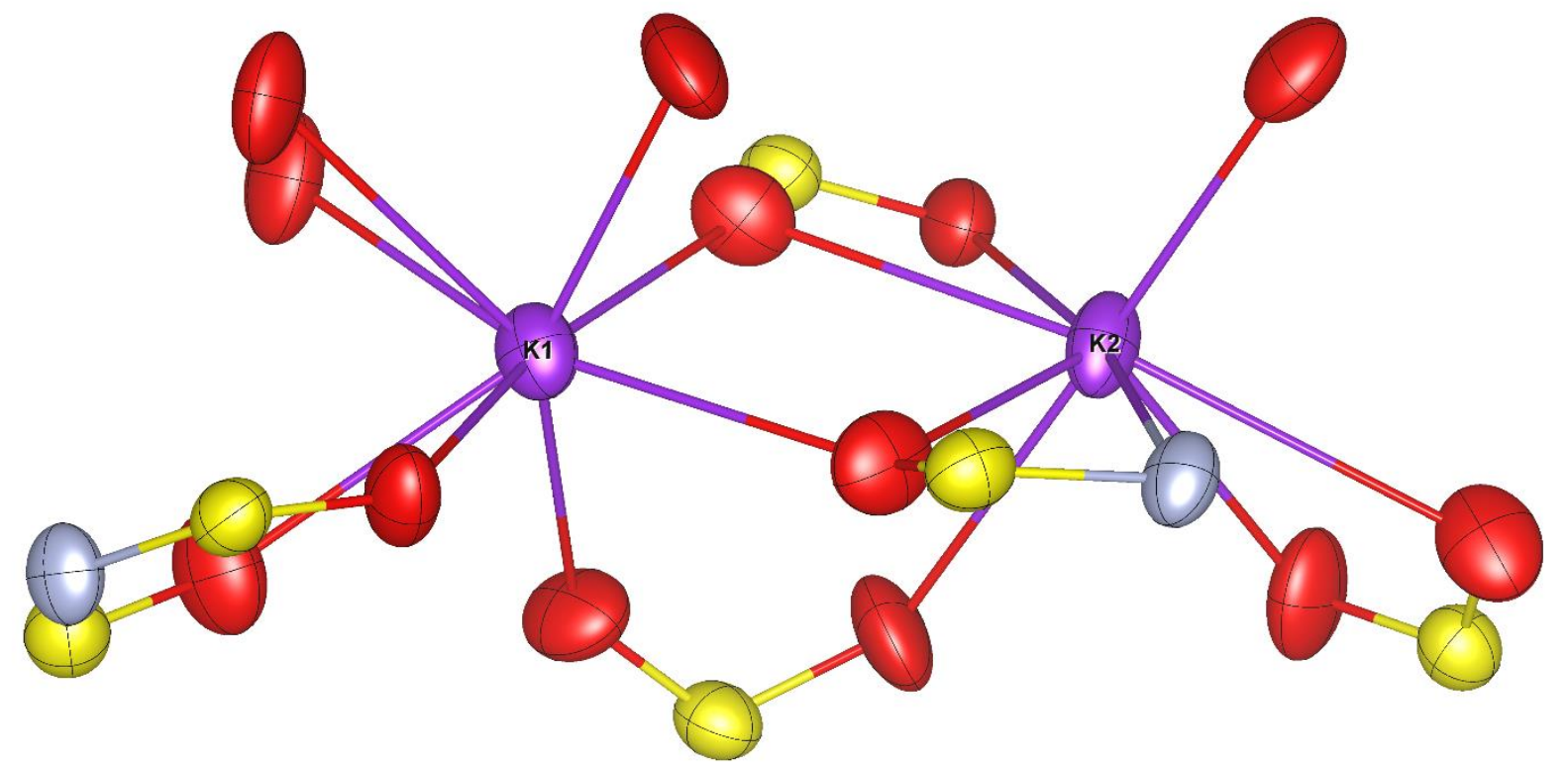

Figure S31. Coordination structure of KTFSI, showing eight coordination number and nitrogen coordination of $1 / 2$ of the $\mathrm{K}$ sites, atoms uninvolved in coordination structures omitted for clarity, thermal ellipsoids at $50 \%{ }^{2}$ 


\section{Linear Sweep Voltammetry}

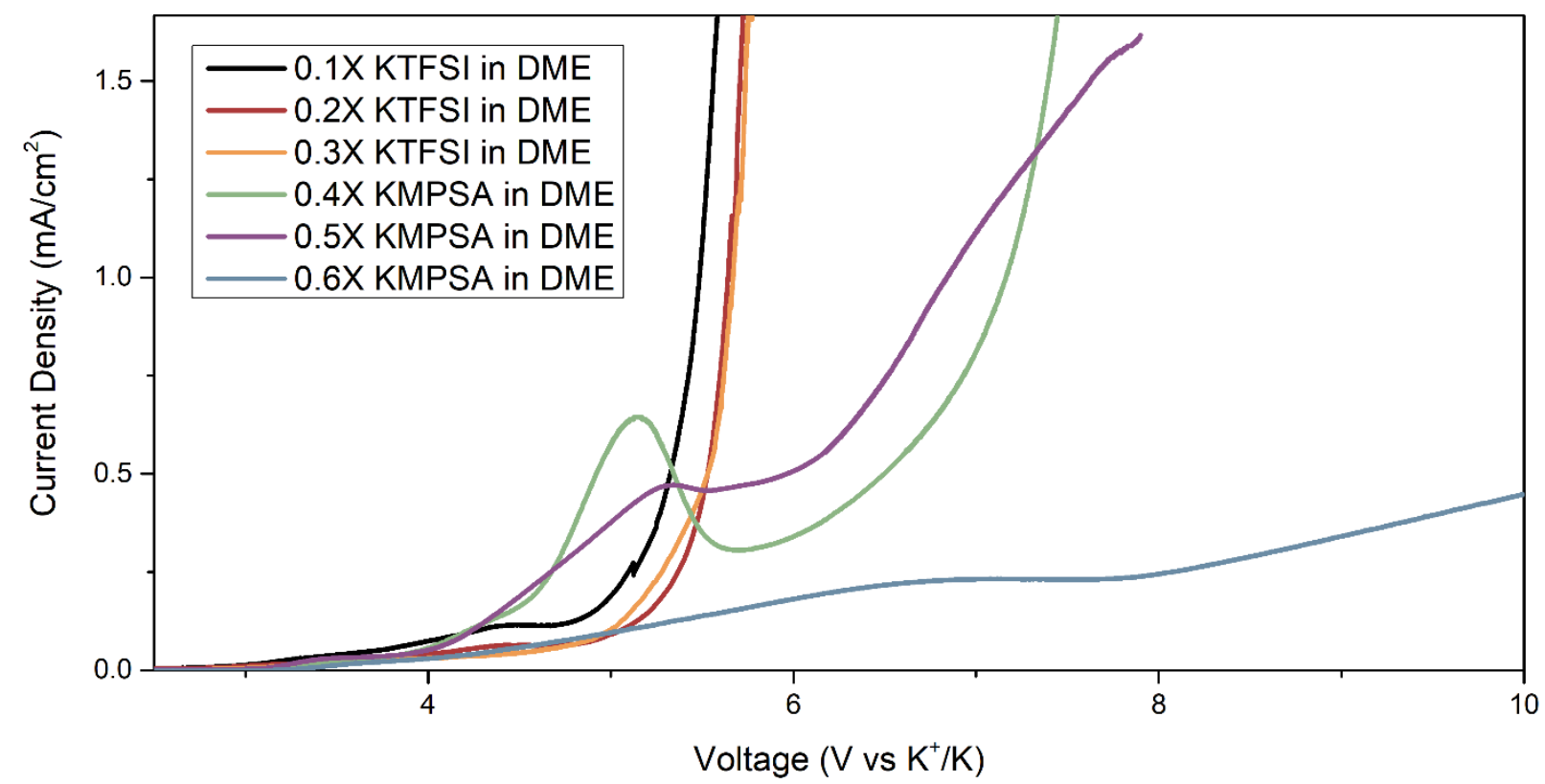

Figure S32. Oxidative window comparison between KTFSI and KMPSA in DME electrolyte. The LSV of each electrolyte was performed using an aluminum foil working electrode with an area of $1.8 \mathrm{~cm}^{2}$ and a scan rate of $10 \mathrm{mV} \mathrm{s}^{-1}$. 


\section{$\mathrm{K} \mid \mathrm{K}$ and $\mathrm{K} \mid \mathrm{Cu}$ Coin Cells Cells}
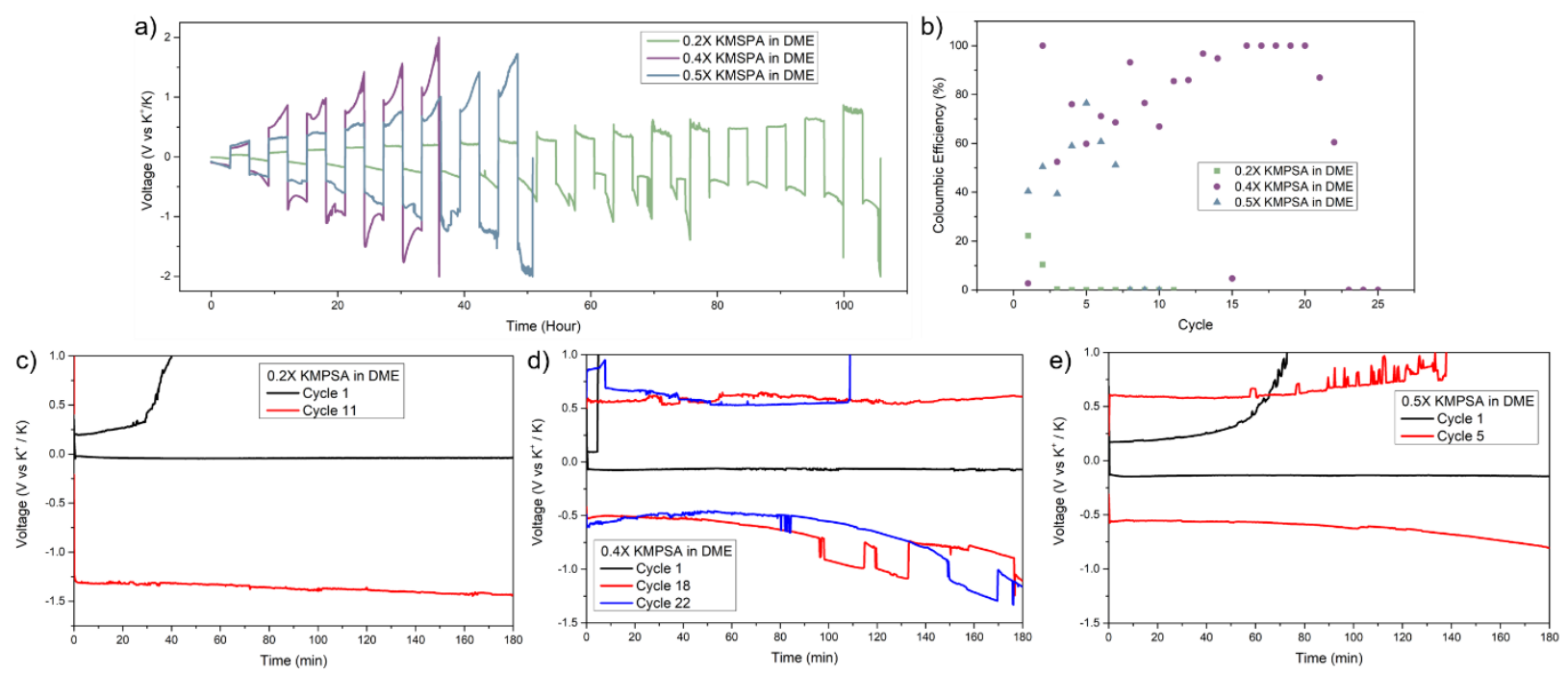

Figure S33. $\mathrm{K} \mid \mathrm{K}$ and $\mathrm{K} \mid \mathrm{Cu}$ cells cycled using $0.2,0.4$, and 0.5 mole fraction KMPSA in DME electrolytes cycled at $67 \mu \mathrm{A} \mathrm{cm}^{-2}$. (a) $\mathrm{K} \mid \mathrm{K}$ symmetric cell cycling voltage indicating relative overpotential of each electrolyte. K chips of a capacity of $24 \mathrm{mAh}$ or $15.6 \mathrm{mAh} \mathrm{g}^{-1}$ were used ( 35mg total $\mathrm{K}$ metal). (b) Comparison of coulombic efficiency for each electrolyte in $\mathrm{K} \mid \mathrm{Cu}$ cells, showing the stability trend of $0.2,0.5$, 0.4 mole fraction (from least to most stable). (c) Voltage profiles of significant cycles for $0.2 \mathrm{X} \mathrm{KMPSA} / \mathrm{DME}$ electrolyte. (d) Voltage profiles of significant cycles for 0.4 X KMPSA/DME electrolyte. (e) Voltage profiles of significant cycles for 0.5 X KMPSA/DME electrolyte. 


\section{$\mathrm{K}-\mathrm{O}_{2}$ Cell using $1 \mathrm{M} \mathrm{KTFSI}$ in DME}
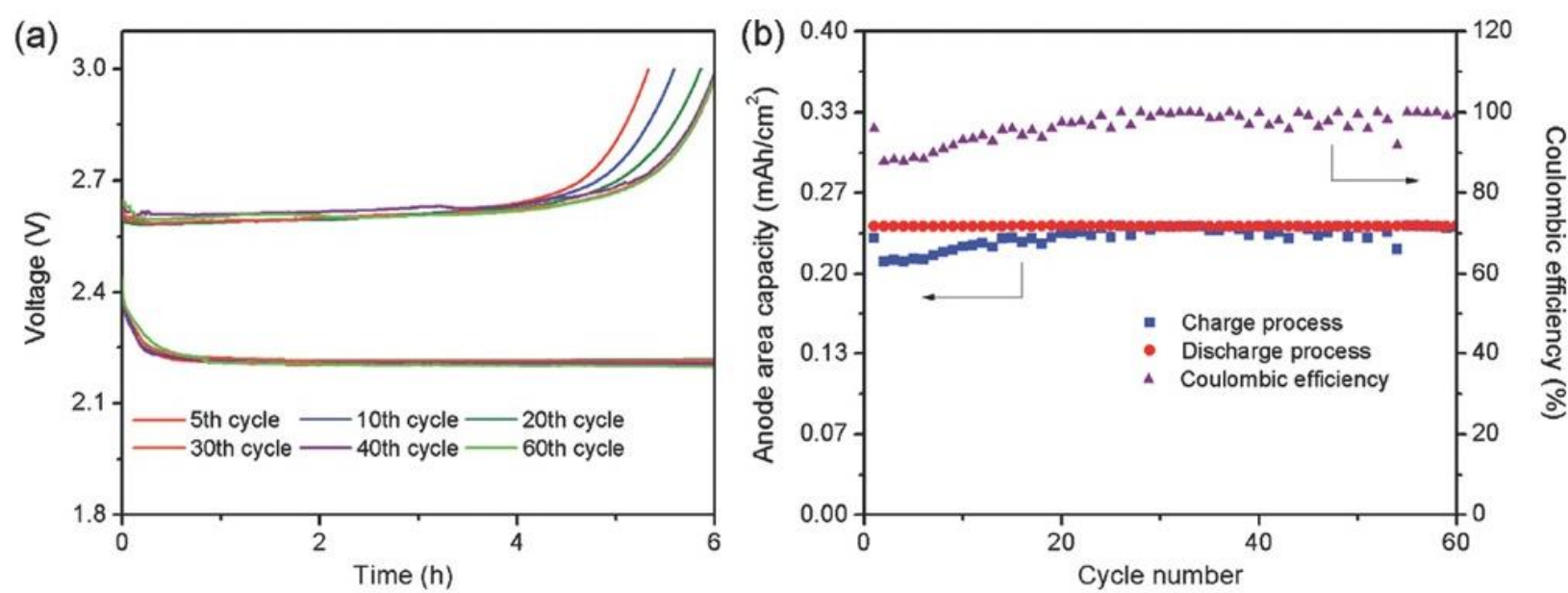

Figure S34. (a)Voltage profiles using $1 \mathrm{M} \mathrm{KTFSI} \mathrm{in} \mathrm{DME} \mathrm{electrolyte} \mathrm{(b)area} \mathrm{capacities} \mathrm{and} \mathrm{coulombic}$ efficiencies of 60 cycles in the $\mathrm{K}-\mathrm{O}_{2}$ battery with $1 \mathrm{~m} \mathrm{KTFSI}$ in DME electrolyte (2 atm $\mathrm{O}_{2}$, current: $30 \mu \mathrm{A}, \mathrm{K}$ anode area: $\left.0.75 \mathrm{~cm}^{2}\right) .{ }^{3}$ Reprinted with permission from John Wiley and Sons. 


\section{Variable Current $\mathrm{K}-\mathrm{O}_{2}$ Cell}

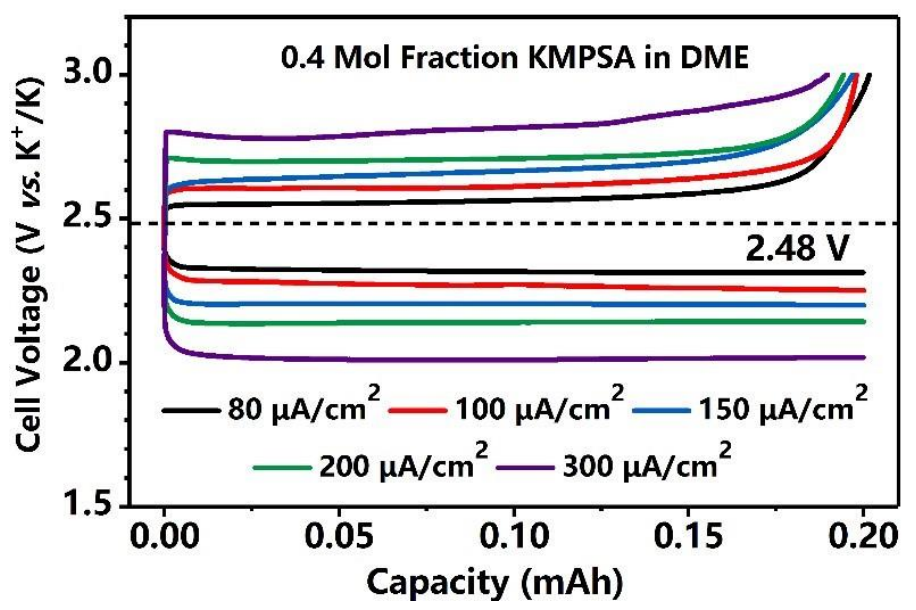

Figure S35. Rate performance of $\mathrm{K}-\mathrm{O}_{2}$ batteries with KMPSA-DME electrolyte. The mole fraction of KMPSA in DME is 0.4 . The capacity is curtailed at $0.2 \mathrm{mAh}$. 


\section{Electrochemical Impedance Spectroscopy}
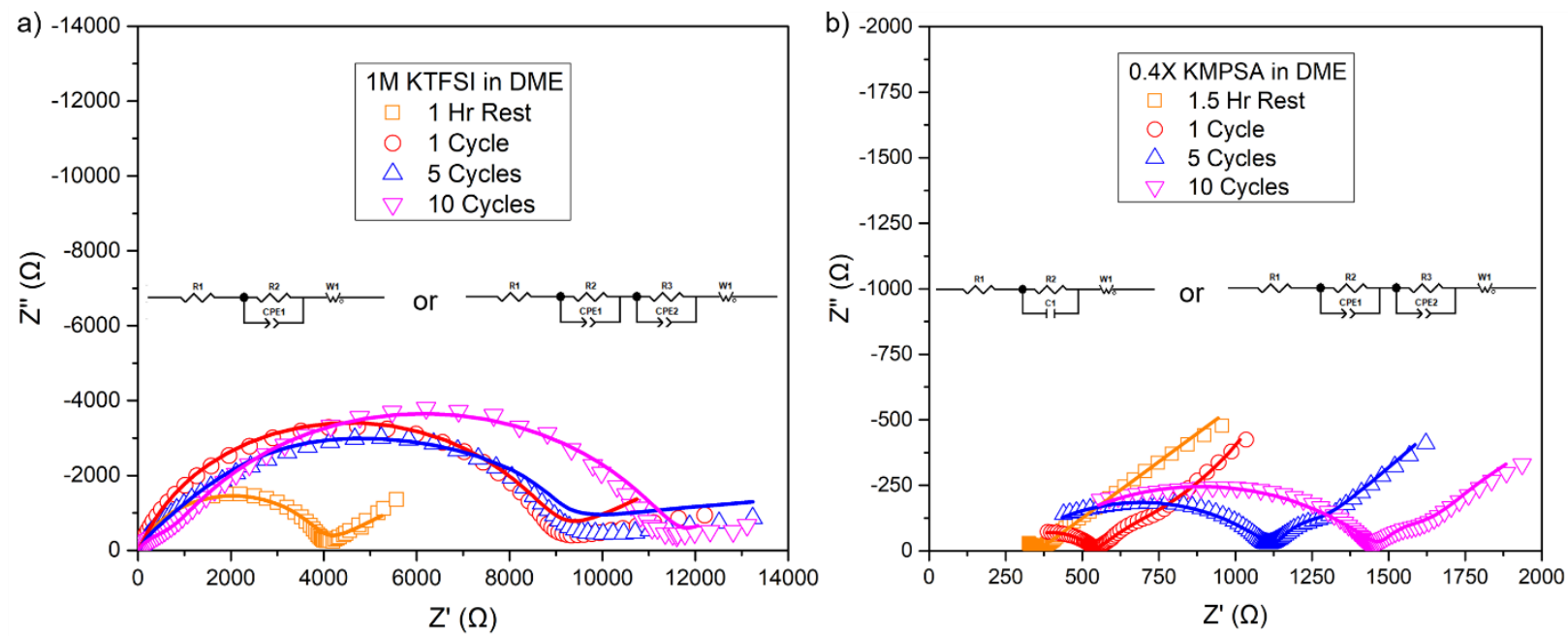

Figure S36. EIS of (a) $1 \mathrm{M} \mathrm{KTFSI/DME} \mathrm{and} \mathrm{(b)} 0.4 \times \mathrm{KMPSA} / \mathrm{DME} \mathrm{K}-\mathrm{O}_{2}$ cells. Both cells were cycled at 67 $\mu \mathrm{A} \mathrm{cm}{ }^{-2}$. The markers represent the raw data obtained, while the lines represent fitted results based on an equivalent circuit. The equivalent circuits are shown in the inserts. For $1 \mathrm{M} \mathrm{KTFSI/DME} \mathrm{the} \mathrm{orange,} \mathrm{red,} \mathrm{and}$ blue lines were fitted with the first circuit, while the pink line was fitted with the second circuit. For $0.4 \mathrm{X}$ KMPSA/DME the orange line was fitted with the first circuit while red, blue and pink were fitted with the second circuit. 


\section{Photographs of K Anodes from K-O2 and K|K Cells}

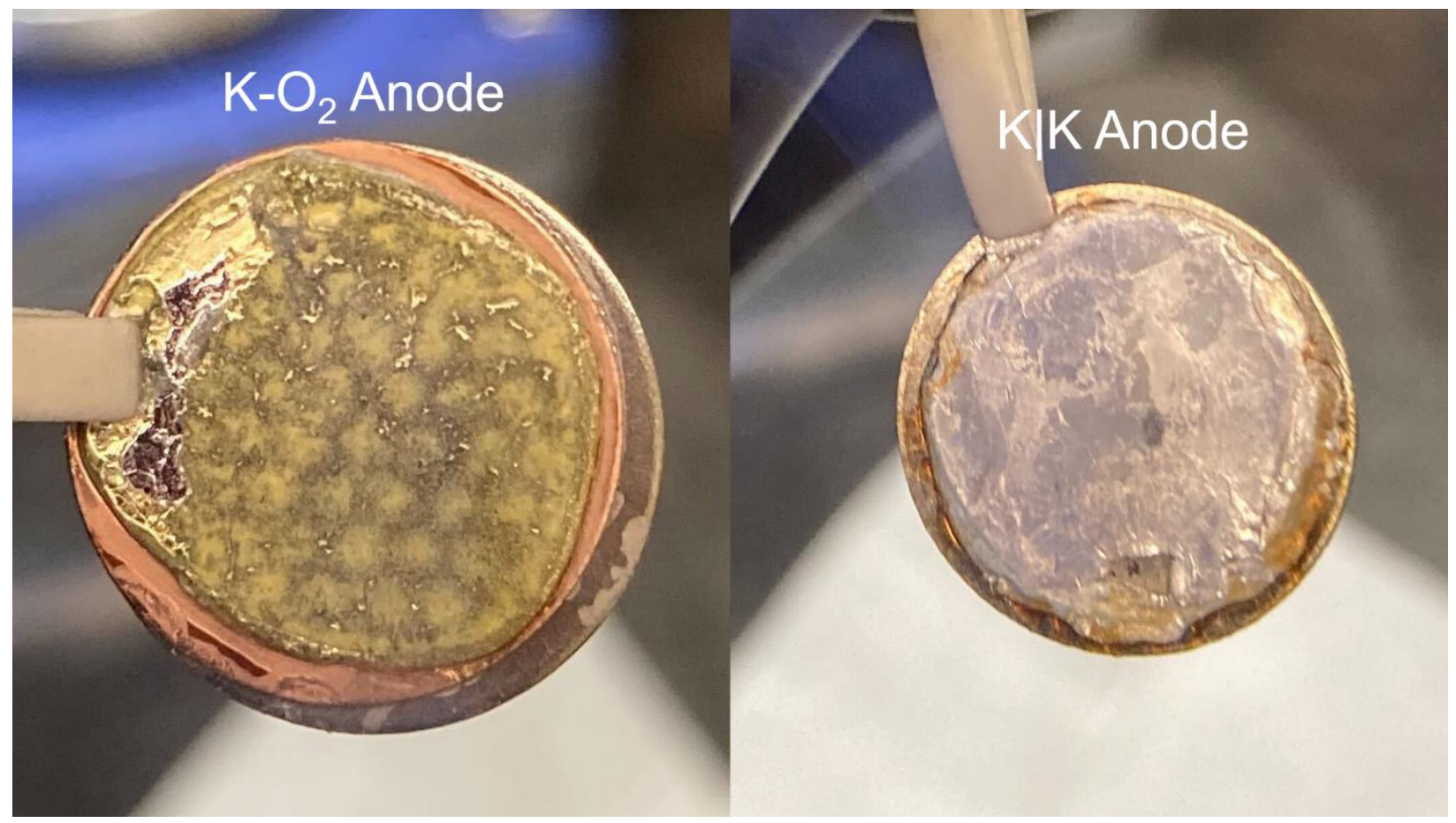

Figure S37. Photographs taken of the $\mathrm{K}$ anode from a $\mathrm{K}-\mathrm{O}_{2}$ and $\mathrm{K} \mid \mathrm{K}$ cell, respectively. Both electrodes were cycling in 0.4X KMPSA in DME electrolyte until failure. Note the large amount of yellow $\mathrm{KO}_{2}$ on the surface of the $\mathrm{K}_{-} \mathrm{O}_{2}$ anode, and the lack thereof in the symmetric cell anode. The circular pattern seen on the $\mathrm{K}-\mathrm{O}_{2}$ anode is due to the mesh spacer used to allow for $\mathrm{O}_{2}$ diffusion into the cathode which imprinted itself on the soft $\mathrm{K}$ metal. 


\section{X-Ray Photoelectron Spectroscopy}

$K 2 p$ and $C$ 1s

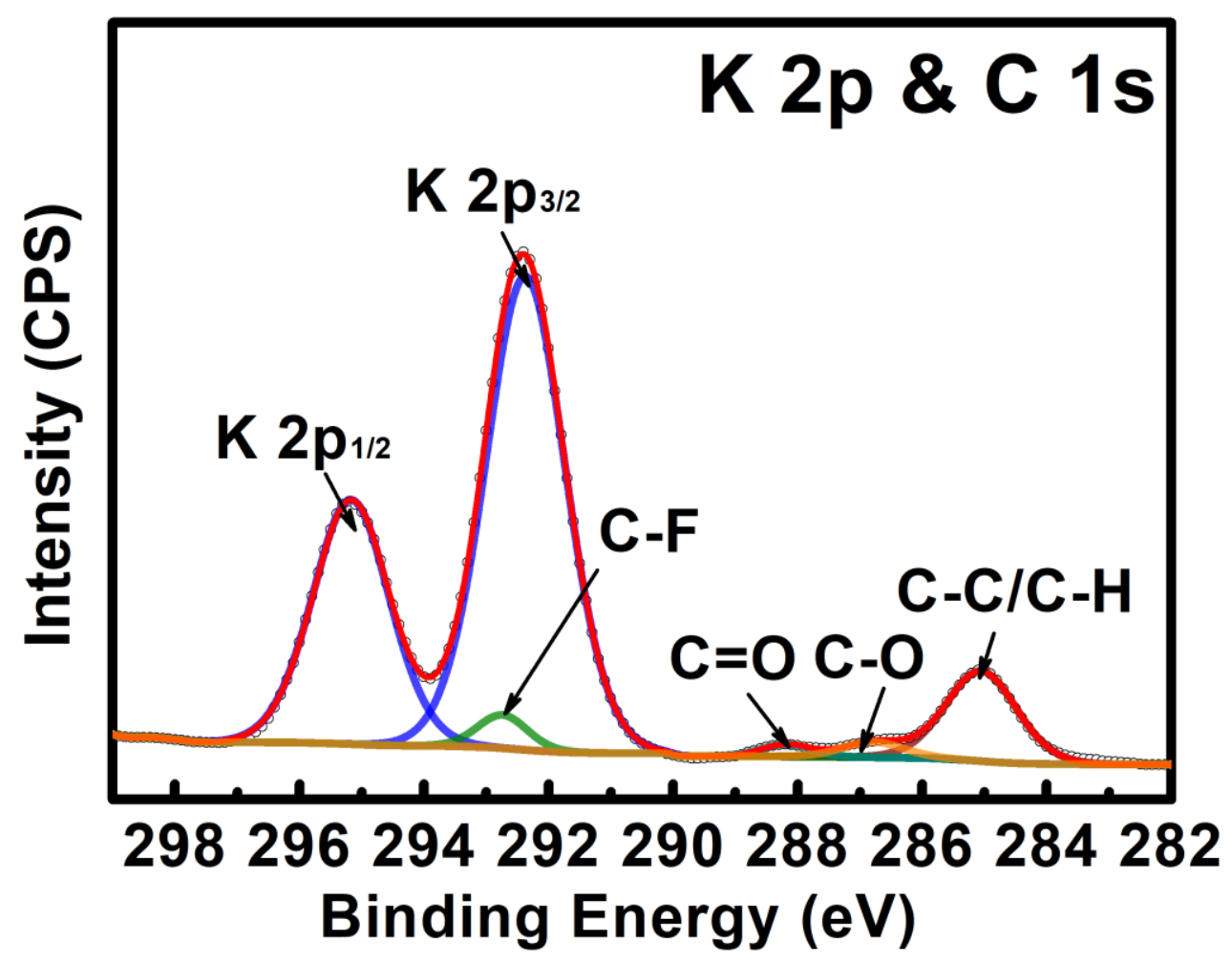

Figure S38. The $\mathrm{K} 2 \mathrm{p}$ and $\mathrm{C}$ 1s XPS spectrum of the $\mathrm{K}$ metal anode from a $\mathrm{K}-\mathrm{O}_{2}$ cell cycled in $1 \mathrm{M} \mathrm{KMPSA}$ in DME after 14 cycles. 
F1s

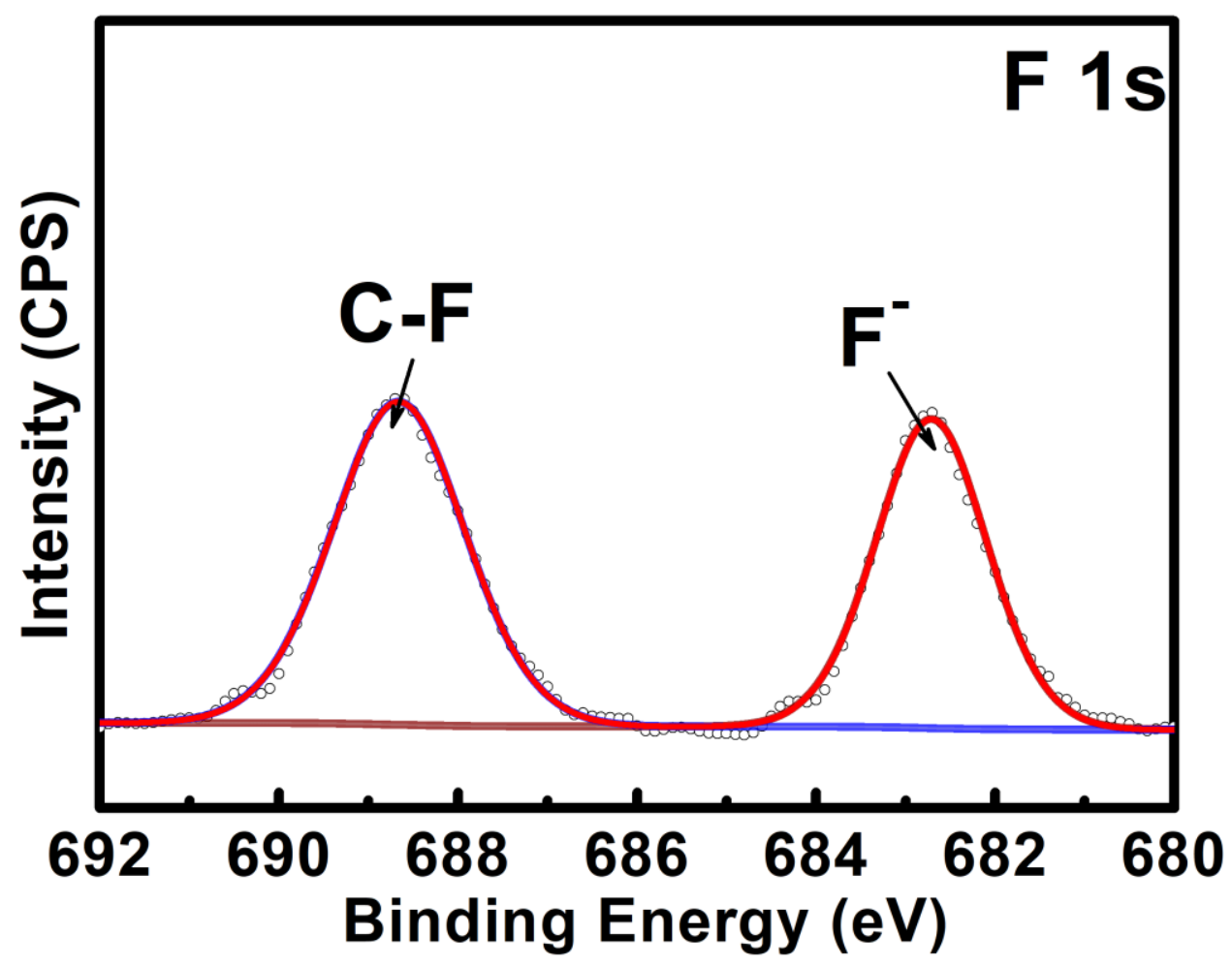

Figure S39. The F 1s XPS spectrum of the $\mathrm{K}$ metal anode cycled in 1M KMPSA in DME after 14 cycles. 
$01 s$

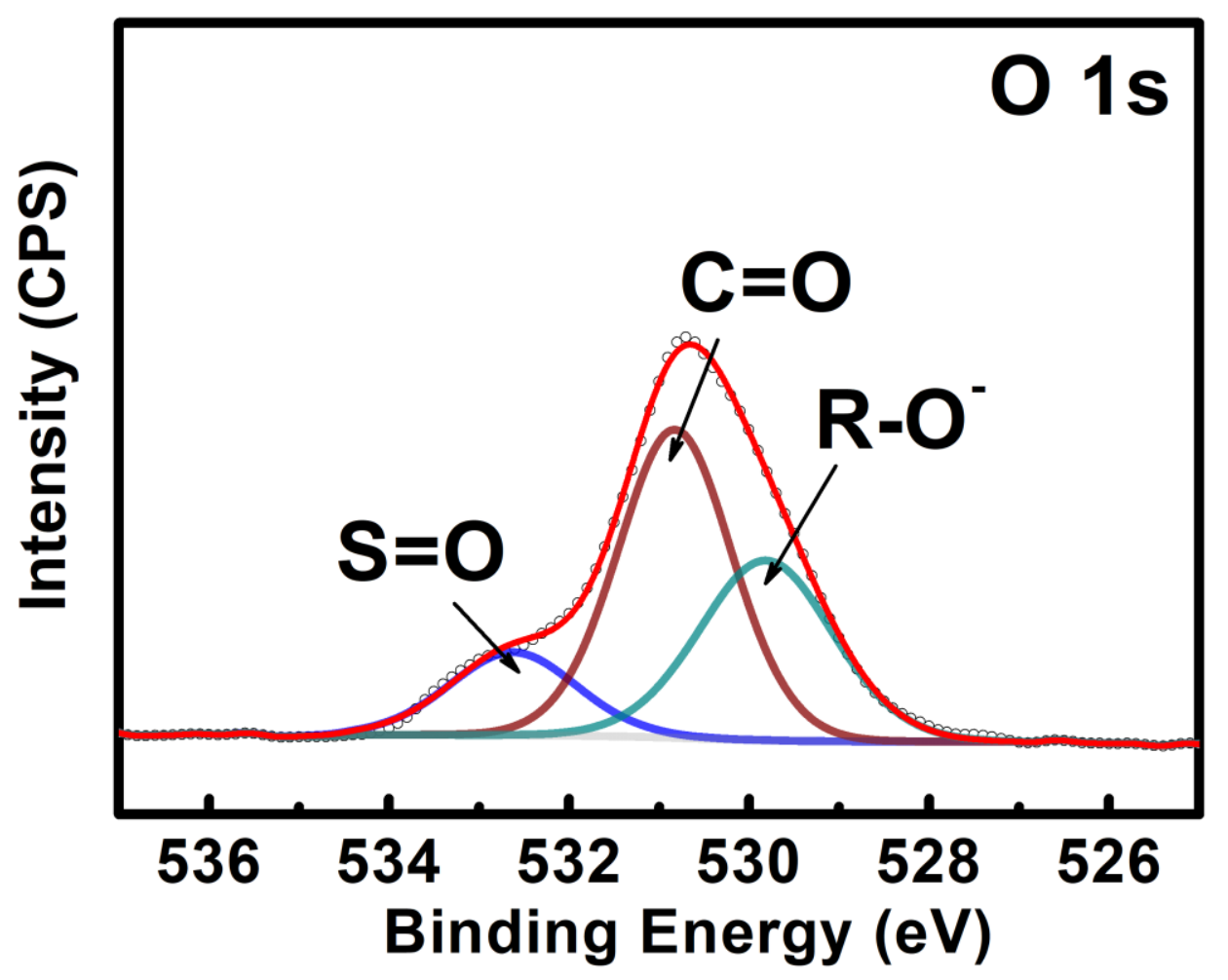

Figure S40. The O 1s XPS spectrum of the $\mathrm{K}$ metal anode cycled in 1M KMPSA in DME after 14 cycles. 
S2p

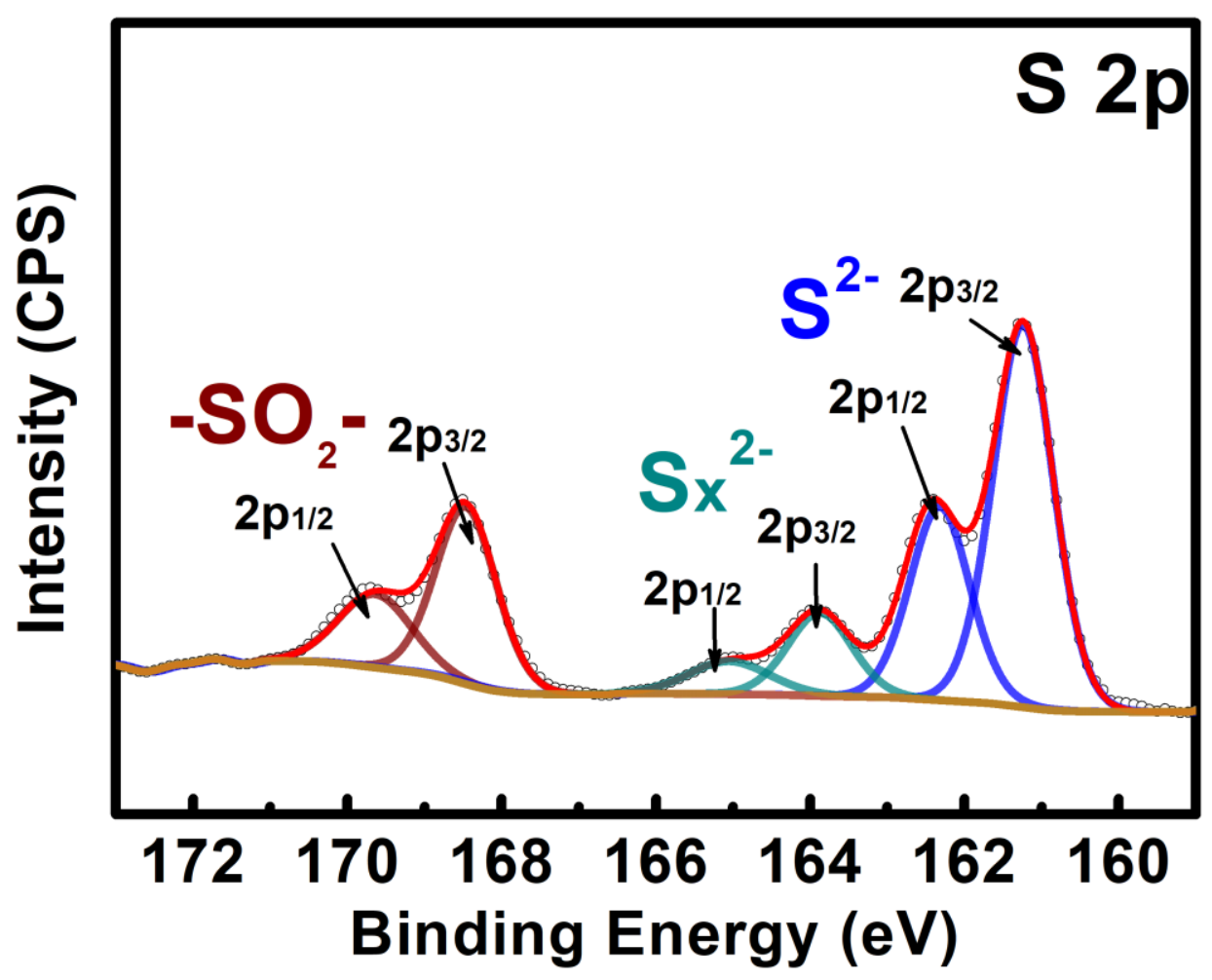

Figure S41. The S $2 p$ spectrum of the K metal anode cycled in 1M KMPSA in DME after 14 cycles. 
$1 M$ KTFSI in DME K Metal XPS
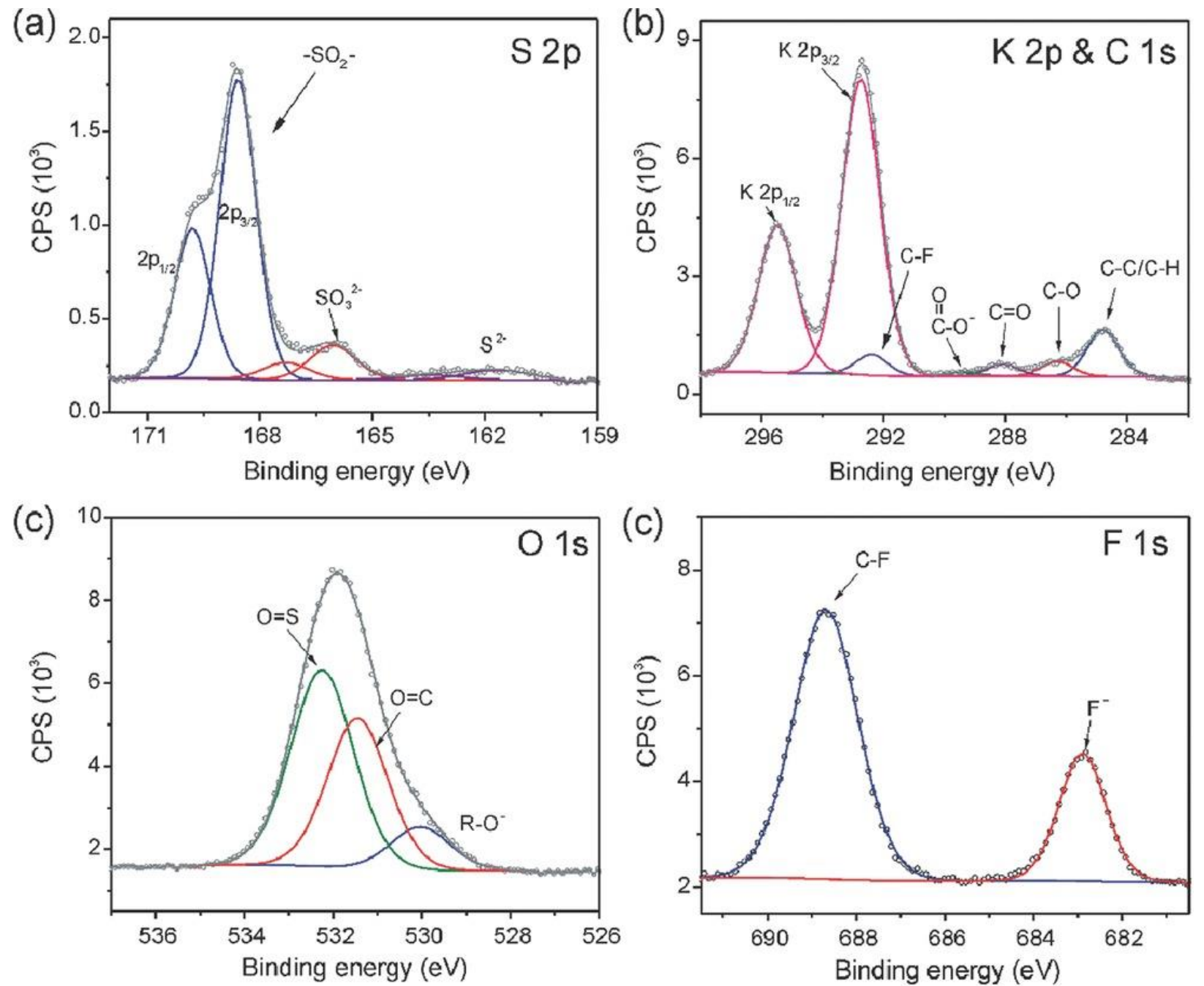

Figure S42. The XPS spectra of the $K$ anode protection layer after ten cycles: a) $S 2 p, b) K 2 p$ and $C 1 s$, c) $\mathrm{O} 1 \mathrm{~s}$, and d) F $1 \mathrm{~s} .{ }^{3}$ Reprinted with permission from John Wiley and Sons. 


\section{References:}

(1) Momma, K.; Izumi, F. VESTA 3 for Three-Dimensional Visualization of Crystal, Volumetric and Morphology Data. J. Appl. Crystallogr. 2011, 44 (6), 1272-1276. https://doi.org/10.1107/S0021889811038970.

(2) Žák, Z.; Ružicka, A.; Michot, C. Structures of Bis(Fluorosulfonyl)Imide $\mathrm{HN}(\mathrm{SO} 2 \mathrm{~F}) 2$, Bis(Trifluoro-Methylsulfonyl)Imide HN(SO2CF3)2, and Their Potassium Salts at $150 \mathrm{~K}$. Zeitschrift fur Krist. - New Cryst. Struct. 1998, 213 (4), 217-222. https://doi.org/10.1524/zkri.1998.213.4.217.

(3) Ren, X.; He, M.; Xiao, N.; McCulloch, W. D.; Wu, Y. Greatly Enhanced Anode Stability in K-Oxygen Batteries with an In Situ Formed Solvent- and OxygenImpermeable Protection Layer. Adv. Energy Mater. 2017, 7 (1). https://doi.org/10.1002/aenm.201601080. 